University of Louisville ThinkIR: The University of Louisville's Institutional Repository

Electronic Theses and Dissertations

6-1949

\title{
A study of the effect of pigmentation on the film properties of ethocel : Part II. a study of the effect of sun light on the color of pigments.
}

Mansur Ahmad

University of Louisville

Follow this and additional works at: https://ir.library.louisville.edu/etd

Part of the Chemical Engineering Commons

\section{Recommended Citation}

Ahmad, Mansur, "A study of the effect of pigmentation on the film properties of ethocel : Part II. a study of the effect of sun light on the color of pigments." (1949). Electronic Theses and Dissertations. Paper 2341.

https://doi.org/10.18297/etd/2341

This Master's Thesis is brought to you for free and open access by ThinkIR: The University of Louisville's Institutional Repository. It has been accepted for inclusion in Electronic Theses and Dissertations by an authorized administrator of ThinkIR: The University of Louisville's Institutional Repository. This title appears here courtesy of the author, who has retained all other copyrights. For more information, please contact thinkir@louisville.edu. 


\begin{abstract}
UNIVERSITY OF LOUISVILLE
PART I

A STUDY OF THE EHEECT OF PIGIENTATION ON THE FIIM PROPERTIES OF ETHOCEL

PART II

A STUDY OF THE EHFECT OF SUN LIGHT ON THE COLOR OF PIGIIENTS
\end{abstract}

\author{
A Thesis \\ Submitted to the Faculty \\ of the Graduate School \\ of the University of Louisville \\ in Partial Fulfillment \\ of the Requirements \\ for the Degree of
}

MASTER OF CHEMICAL ENGINEERING

Department of Chemical Engineering

Mansur Ahmad

June 1949 


\section{UNIVERSITY}

LIBRARIES

This PDF document is a scanned copy of a paper manuscript housed in the University of Louisville (UofL) Libraries. The quality of this reproduction is greatly dependent upon the condition of the original paper copy. Indistinct print and poor quality illustrations are a direct reflection of the quality of materials that are available for scanning. The UofL Libraries greatly appreciates any better copies that can be made available for replacement scans. 


\section{PARI I}

A study of the effect of Plgmentation on the I1Im Properties of Ethoeel

\section{PART II}

A Study of the Effect of Sun light on the oolor of Plgments

\section{Mansur Ahnad}

Approved by the Examining Committee.

D1reotor $\frac{\text { R. C. Ernst }}{\frac{\text { G.C. Williams }}{\text { R. A. Williams }}}$

June 1949 


\section{CONHENTS}

\section{PART $\mathbf{I}$}

A STUDY OF TEE BFECT OF PIGUSITATION ON THE FIU PROPERTIES OT ETHOCEL

Iage

Llet of vables $\ldots \ldots \ldots \ldots \ldots \ldots \ldots \ldots \ldots \ldots \ldots \ldots \ldots \ldots \ldots \ldots \ldots \ldots \ldots \ldots$

List of 1 1gurve $\ldots \ldots \ldots \ldots \ldots \ldots \ldots \ldots \ldots \ldots \ldots \ldots \ldots \ldots \ldots \ldots \ldots \ldots \ldots$

Aoknowledgment to the Mreotor ................... vi11 Abatraot $\ldots \ldots \ldots \ldots \ldots \ldots \ldots \ldots \ldots \ldots \ldots \ldots \ldots \ldots \ldots \ldots \ldots \ldots \ldots \ldots \ldots \ldots \ldots$

Introduot1on $\ldots \ldots \ldots \ldots \ldots \ldots \ldots \ldots \ldots \ldots \ldots \ldots \ldots \ldots \ldots \ldots \ldots \ldots \ldots$

H1stor10al $\ldots \ldots \ldots \ldots \ldots \ldots \ldots \ldots \ldots \ldots \ldots \ldots \ldots \ldots \ldots \ldots \ldots \ldots \ldots \ldots \ldots \ldots \ldots$

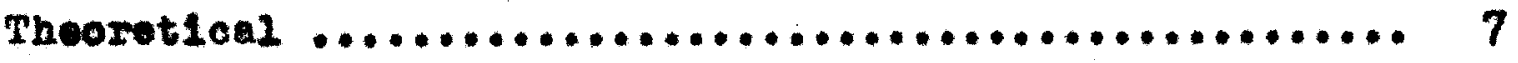

Ixpertmontal $\ldots \ldots \ldots \ldots \ldots \ldots \ldots \ldots \ldots \ldots \ldots \ldots \ldots \ldots \ldots \ldots \ldots \ldots \ldots \ldots \ldots$

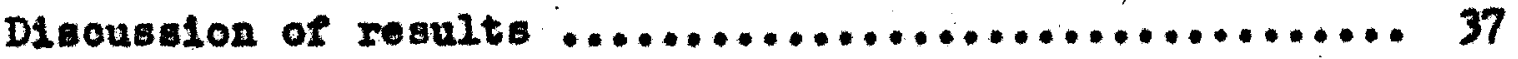

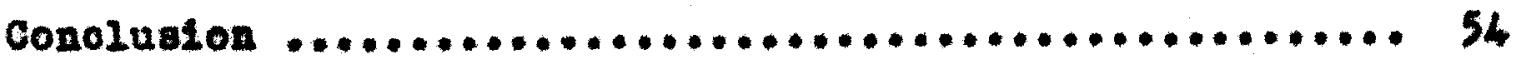

Litereture cited $\ldots \ldots \ldots \ldots \ldots \ldots \ldots \ldots \ldots \ldots \ldots \ldots \ldots \ldots \ldots \ldots \ldots \ldots$ 


\section{LIST OF TABLES}

TART I

I. Physloal Properties or P1gment ....................

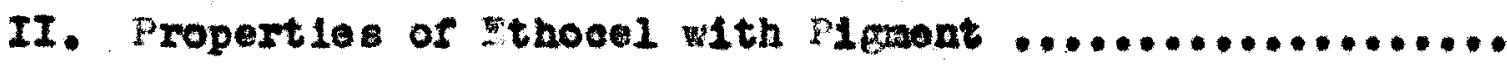
III. Properties of sthooed with fitanox ................... IV. Propertien of Ithoeed with Lithopone .................

v. Properties of lithoeel with cellte .................... AFTER

vI. Properties of Ethooel with vioalite ..................

VII. Properties of Ethocel with Barytes .................... VIII. Froporties of ethooel with Sentooel

Ix. Propert1es of Ithocel with Bentonite................. x. Properties of Ethooel with China clay ................ 


\section{LIST OF TABLES}

PART II

Page

I. Sample Calculations .................... 131

II to XXIII. Maobine readings and Calculated I.C.I.

values ....................... Arter Pert II 


\section{LIST OF PIGUKES}

PART I

Figures

1. Variation of Sortening and Helting point with Sthoxy Content

2. Variation of Softening and Melting Polnt of Plastiolsed Ithocel with Bthoxy Conteat ..

3. General Efrects of Resing on the Yield Polnt and Flongation of Ethocel Fling ............ 18

3. Soott Tensile Tester...................... 26

4-11. Variation of Softening and Nelting Point with Poroent Plgment ...................... 39

12-18. Veriation of Tensile strength with P1 gmont ... 46 


\section{LIST OF FICURES \\ PART II}

19 Diagram of Multipurpose Refleotometer ........66

20 Multipurpose Rerlectometer ...............68

21 Variation of Permanenoe with Exposure Hours ....84

22-50 Variation of Br1ghtness, Saturation and Hue with Time ............................. 86 
$\nabla 111$

ACKNOWLEDGUMTY 
The author wishes to acknowledge the kind asalstanoe and helpful guidanoe of

Dr. R. C. Irnat

and

Dr. G. C. W1121ams

who dreeted this researoh 
PART I

A STUDY OF THE GHTECT OF PIOMENTATION OR TAE FILM PROPERTIES OF ERHOCEL

ABSTRACT 
The purpose of this investigation was to determine quantitatively the effeot of plgmentation on the film properties of ethocel laoquer. This study was confined to the determination of tensile strength, percentage elongation at fallure, softening and melting polnts of the flims. Plgments were ground in the othooel lacquer containing three parts ethocel, one part $276 \nabla-9$ Dow reain and sixteen parts of solvent by welght.

Softening and melting points of the films were determined and were found to increase uniformily with inoreasing amounts of the pigments.

The tenalle strength of ethooel film with titanium dioxide as a plgment increased from $317 \mathrm{Kgm} / \mathrm{Cm}^{2}$ to 425 $\mathrm{K}$ bed $\mathrm{Cm}^{2}$ by adding 2 pereent followed by a deorease. Similar but less marked results were observed with lithopone, barytes and dealte. 
INTRODUCTIOA 
f considerable emount of work has been reported on the effect of plentation of films obtalned from vehicles oontaining 011 and resin comblnations. Some data have been reported on the $111 \mathrm{n}$ properties of plgmented cellulose nitrate (3), but It is only reoentiy that the importance of studying the film properties of plemented othooel was realized. Th1s lack of Interest in ethocel can be traced to the relatively recent appearance of this material comerolally. It is today competing with nitro oellulose in the manufaoture of lacquers. Unt1l very recently ethooel has beon selling at price higher then that of nitro-0ellulose. The properties were considered simllar to nitro-0ellulose, but reoent studies have shown that it offered greater advantages than nitro-cellulose in having greater resistence to ultra-violet rays, greater rlexibllity and toughness (4). When the sects were brought to 11ght, great deal of effort was made to manufacture ethyl-cellulose at a price comparable with nitro-cellulose. With Its inoreasingly greater applieation it became more and more important that the fIIm properties of plemented ethocel be studied.

Iittle work has been reported on the plemented film properties of ethocel, espoolally on those properties whloh have direct bearing on the lacquer contalning ethyl cellulose. Hence, it was considered that more information on the effect of inorganio flilers and pigments on the ethocel film properties would be desirable. This was of special interest sinoe it might be of great advantage to 
ralse the molting point of a lacquer film without affeoting the other properties. An 1norease in the sortening point of such f1lms would open new flelds for the applioation of ethooel. It oould be used for protection or for ingulation of those parts of eleotricel instruments whioh experience temperature rise during operation. Again, if an increase in tensile strength of ethooel film oould be achieved, it would be of considerable importance to the lacquer industry and the wrapping film industry.

There were 1ndications from certain past work that the presence of these fillers in smell amounts might acoomplish that purpose but no quantitative work has been reported on the subject.

The general aspeots of this problem included the desire to determine what effect the plementation of laoquers have on flin properties. It had always been assumed and realized that pigmentation did deorease flexibllity and tensile atrength but it had never been oonfirmed as far as the available literature on the aubject is conoerned. 
HISTORICAL 
Ithooel is a relatively new produot whioh is today competing with nitro-0eliviose in the manufaoture of laoguers. It has the advantage of ereater flexibility, greater toughness and has greater resistance to ultra-violet $11 \mathrm{ght}(3)$. sthooel is being put on the market by American manufacturers at mach lower cost than in 1937. At the same t1me, these manufacturers have been ourrying on extenalve researeh for the development of better and oheaper methods of making -thoeel, and aroat deal of resoaroh is being conduoted to Inrestigate the properties of ethooel.

Little quantitative work has been roported on the study of the effect of plementation on lacquers. Howerer, there is nom indireot ovidenoe wich leads one to expeot thet the properties of laquers flim could be modifled by the addition of plemants.

It has been polnted out (2) that the application of collold ohemical teohnigues to the study of hlgh polymers has shown that they consist of mixtures of nolecules of afferent alze or degree of polymerization, so that the large molecules of oellulose derivatives for instance, ylela stronger, and shorter moleoules gleld weaker rilm. However If a small amount of $10 \mathrm{w}$ moleoular welght material is added to moh larger quantity of high moleoular wolght material an Inorease in film atrength is observed. This is belleved to be the result of f1lling up the gaps between the large moleeules by the emeller moleovles. In 1946, Dann and Baler 
after a long experimental study presented some data whioh showed that the tensile strength of paint film (Iinseed ol] as reh1010) was Inoreased by the addition of titanium dixolde. Som suoh offoot was also obtained with other inorganio plements to a lesser degreo. 
TEORLMIOAL 
To oxplain and to aooount for the behaviour or cortain plements when adured with a laequer containing. ethooel, it will be adrisable to study the structure and physionl properties of the constituents. The oonetituente under conalderation are ethooel, reain, toluene and ethanol as solvent and diluent oonstituting the leoquer; and titanium dloxide, baytes, lithopone, diealite, sentooel, 0olite, or ohina olay as the plgmenting agents. Nore of these plgants montioned have any epprodable chemloal reactirity with the laequex constituents; henoe ohemeal properties will not be cons1dered.

Cellulose:

A cellulose moleoule consiste of a long oheln of oelloblose units jolned togethor by means of Bulueoside 11nkages.

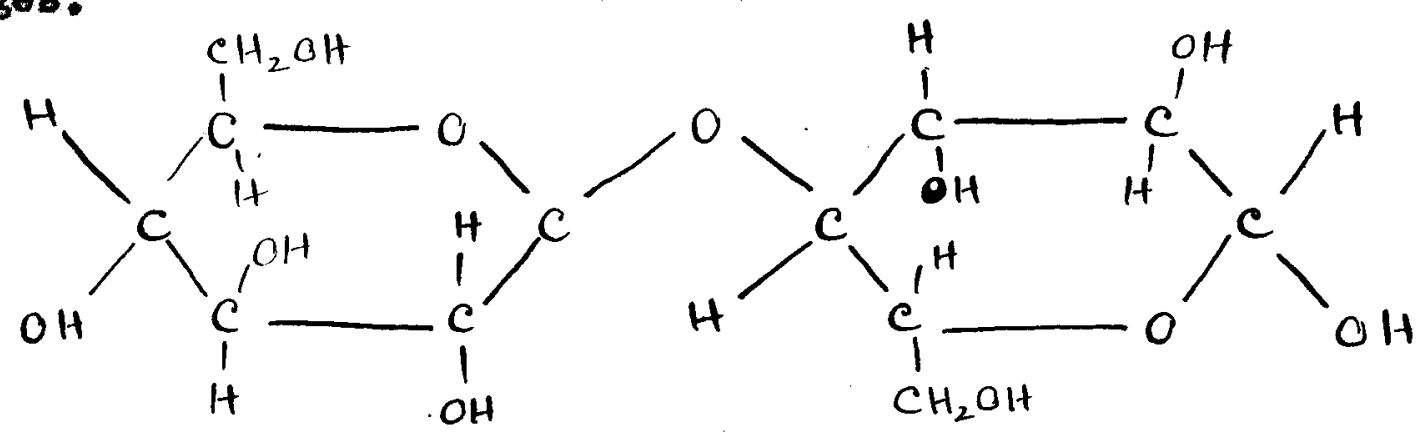

Colloblose
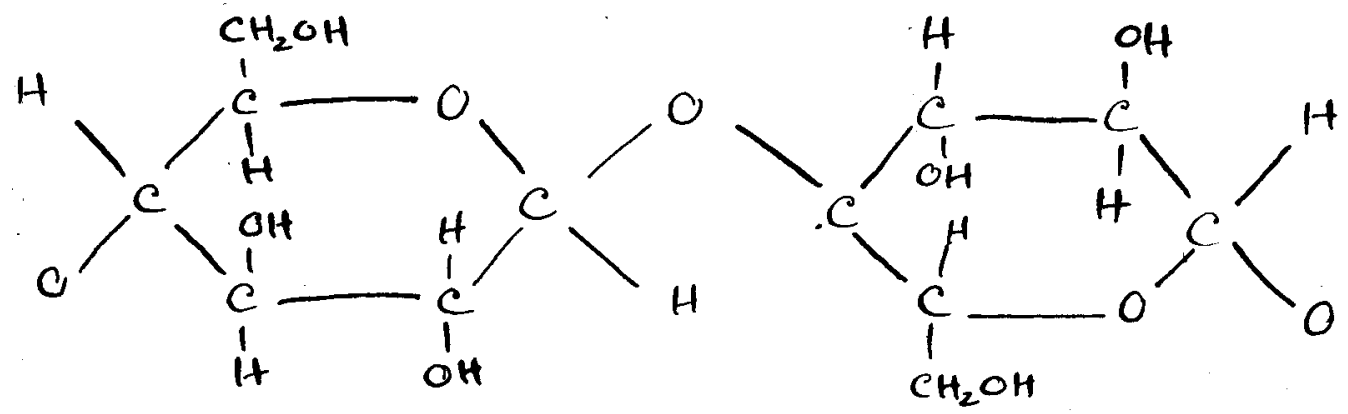

Cellulose 
The terminal groups of the oellulose moleoules are hydroxyl groups (-OH), there being four hydroxyl groups in the end residue (21).

The moleoular wolght of eellulose has been deterwincd by varlous methods and is found to vary with different mothods used, ranglng from 30,000 to 450,000 ,

By X-liay studies, It has beon found that oellulose chains or at least somo parts or then exist in an oriented parallel, orgstalline syston, shown in the fleure by darker IInes, with amorphous divisione interupersed along the molecular ohain.

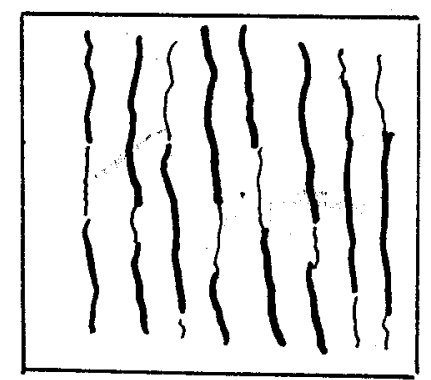

Cellulose 14001100 (19)

Ithyl-0ellulose is an ether of collulose. Its manufaoture consists of converting cellulose into alkall cellulose by treatment with atrong aquoous solutions of sodiun hydroxide. This elkall collulose is alkylated with woh reagente as othyl ohloride or othyl sulphate (6). The formation of diethyl collulose may be Indioated followe: 


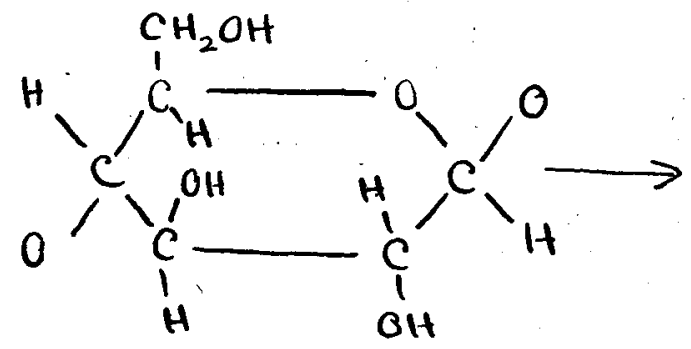<smiles>O[C@H]1O[C@H](O)[C@H](O)[C@@H](O)[C@@H]1O</smiles><smiles>CCCCCCOC1(OC)C(OC)C(OC)C(OC)OC1(C)CCC</smiles>

Than may be one, two, or three ethoxy groups per cluooe unit. The pereentage e1mply represents the arerage number of substituents groups per gluoose unit.

To arold degeneration of the cellulose and the alkgleting agent, the alkglation is acoomplighed with rery oareful temperature oontrol. When the reation is completed, the reagent and the by-products are apereted by washing and bJ alatiliation. By repeated washinge with watex, the purIfleation of ethocel is Inally completed.

Certaln physieal properties of ethy oellulose copent upon the degree of alkglation, as for example, aolubility. A produet heving 27 peroent ethoxy eontent is ooluble in water, alohol and aold, but, as the pereentage of othoxgl lnoreabes above 27 pereent, the water solub111ty deareaves and the solublilty in organio solvents inoluding arying olle inoreased (21). 
The tenstle etrength of the degraded riberous produote like ethyl allulose is moh lower than that of natural oellulose 11lm. The tensile strength here aepends upon the secondary ralenoe forees.

In the rupture of this short ohained, lese orlented at ruoture, the alippage of the ohains past one another 10 of primary importance. The degree of orlentation, the chain length, the chemieal nature of the chnin and the presenes or absence of any plastielzing agent (1noluding molature) are all offeotive in the determination of the sooondary ralonee foroe whioh will be exh1bited. These intermoleoulex attreotive foroes in tarn determine the ease wth wioh oonstituent ohalns 411 ollp past one another. Jnder sueh oond1tione the tensile atrength of these degreded flbers is somowhat lower than that of native cellulose.

The teneile atrength and longation of ethoeel I1In: are Afretiy related to the Intrinalo risoonity of the material used. These properties are higher and the toughness and flexibility of the flles are greater with the higher riscosity types of othooed. There is an improvement in the filin strongth and flexibility with inoreased latringlo viscosity of the oellulosio material (22).

The effeet of the inoluetion of resin is to gate ethocel lacquers hardnese, adhesion, and glows. The hard resing increase these propert1es to the greatest extent. Ethoeel and the realn used require soltents which will 
diseolve oach of thor, so that they may form a laoquer sultable for spraying or brushing.

The solvents used in the laoquer Industry hare a whe range of bollling polnts and evaporation rates. The -vaporation rate greatiy arfeots the final condition of the 111m. A fast evaporating solvent may oause sreall pits or holes and these imperteotions will oave low flexibility by uneren dietribution of stresses.

The sortening and melting polnte of ethooel film or any laoquer film oan be determined with a certaln amonnt of coouray on a "Denl: shelton" (10) melting polnt bar. This apparatus cons1ate of a sol1d oopper reotanguler bar about sixteon Inakes long. The bar is heated at one end by moans of an eleotrio heating element so that there is a cradent in temperature along the bar. Detalls of this apperatue are disoussed later on.

The softening point of a $111 \mathrm{~m}$ is that temperature at whioh the f1lm becomes appreclably plastio.(22) The molting point of a I1Im ta the temperature at whioh the $111 \mathrm{~m}$ beglas to stlok to the ber. The sortenting and melting polnt or ethoeel are dependent to nome extent upon the Ithoxy content of the oellulese molecule. It has been found that the greater the number of Ethoxgl group attaobed to the 0ellulose moleoule, the lower are the gortening and melting polnts. This oan be soen from the sortening and molting pelat ourres of 11gure $1(22)$. 
A plastielzer aded to othoed, lowera the sortening and molting polinte, but the raxiation of sortening and woltIng points with othos content followe a similar trond as in 11gure 1. Bubh an effect is shown by the ourtes in flgure 2 (22). The resing unuelly exployed in the laoguer induatry heve melting polnt sange of from o degree contlerade to 150 degrees cent1 grade. Whey oan be used to vary the oharacter of the f1lmu. 


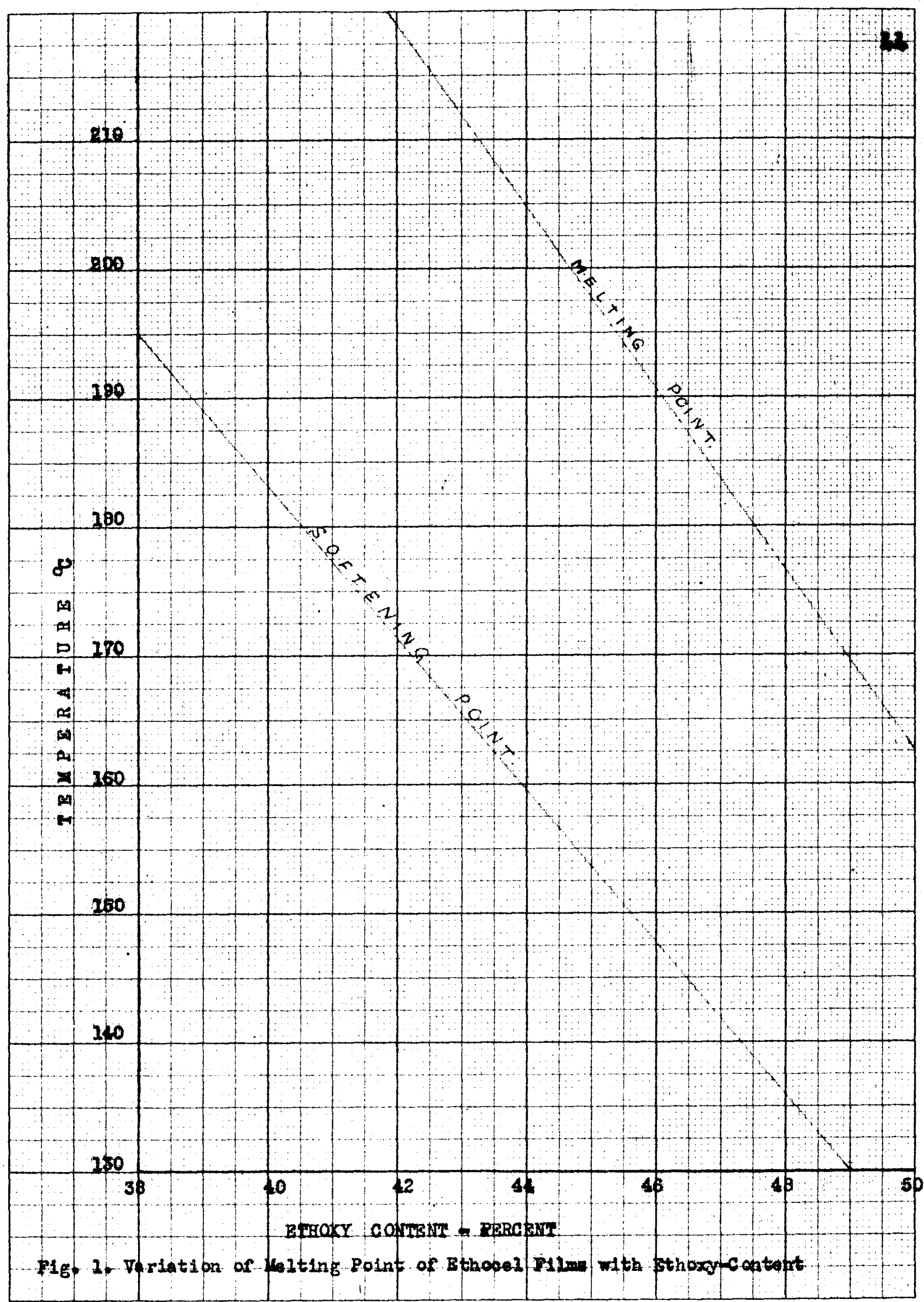




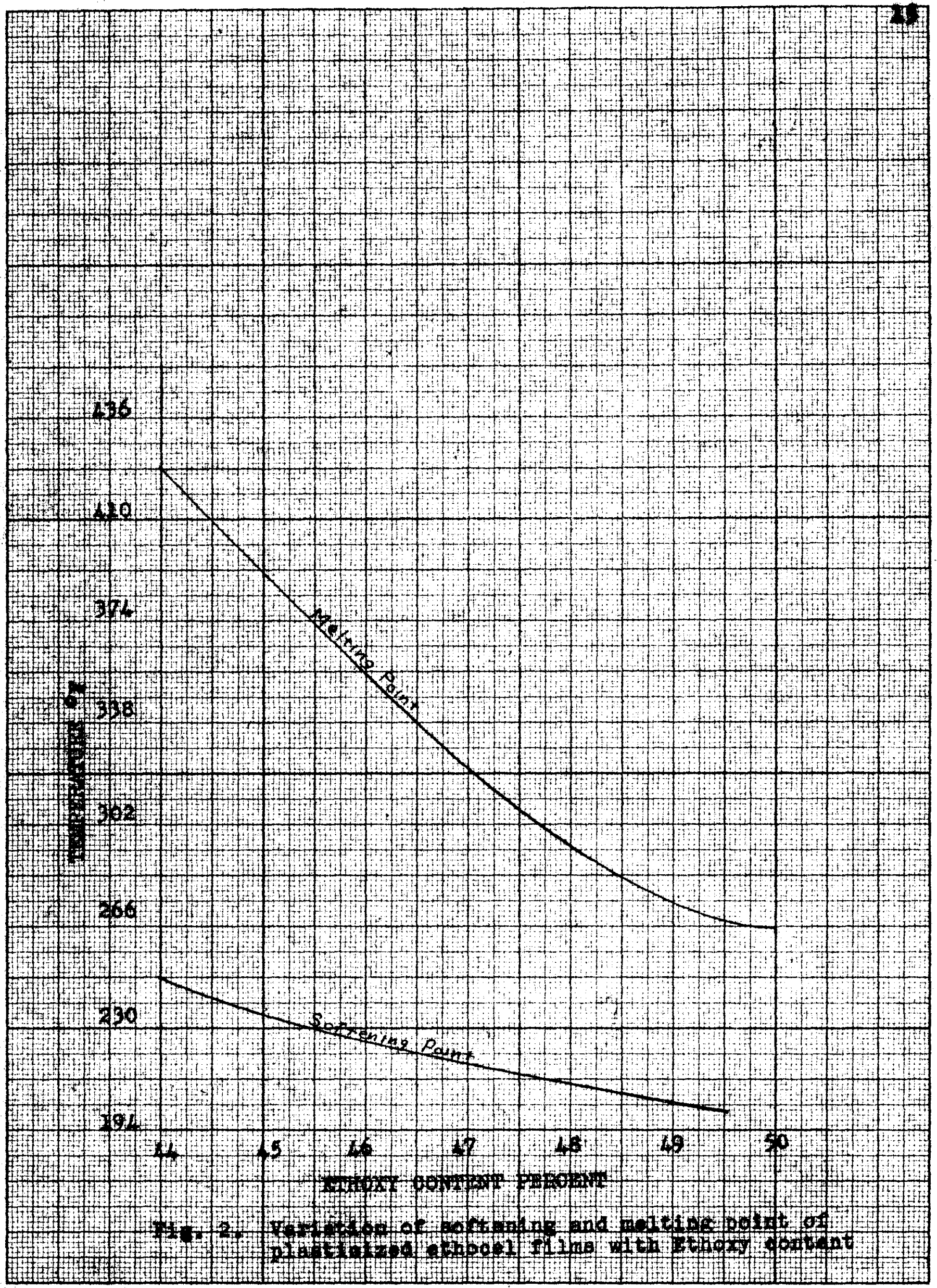


Ithooel has been found to be compatible with a great variety of natural and synthetio resins. It 18 completely compatiblo with pure phenolios, modifled phenollos, rosin, rosin esters, and toluene sulfonamide formaldehydo. . The solvent used for determining the compatiblifty data 18 80:20 toluene-ethenol solution since th1s solvent produces low solution visoosity and, in general, high strength of doposited ethocel film. Aloohol has the property of reduolng the vioosity of the solution. : The resin may increase the hardness of the film so that the tensile strength increases and Ilexibility deoreases. Tet some other resin may affoet the hardness rery slightly but may not deorease the Ilexibility at all, and finally the resin may work like plastiolzer as shown by the curves in figure 3 (22). The f1rst olass of resins 1s classifled as hard resins, seoond as modium, and the last as soft resins. Resing producing results lying between these olasser are also avallable so that any desired condition oan be obtained.

Laoquers differ from oleoresinous paints and enamels in this respeot, that pigments are inoorporated to give the dealred color to the laoquer. An arerage paint can contain alx or olght pounds of plgment per gallon, but such a large amount, if used in a laoquer, wll yleld product of low durability and poor adhesion (23). The high volatile content of laequers as compared with oleoresinous 
material shows that there 18 less binder to hold the pignent partioles together. Thus the plgments used in looquers are somewhat different from those used in other types of finishIng materials. In general pigments of low oll absorption, hlgh hiding power, and greater strength give the best results. Both plgment rolume concentrations and speoiflo surface of the pigments are important. A decrease in the partiole size of pigments is acoompanied by an inorease in visoosity (15). 


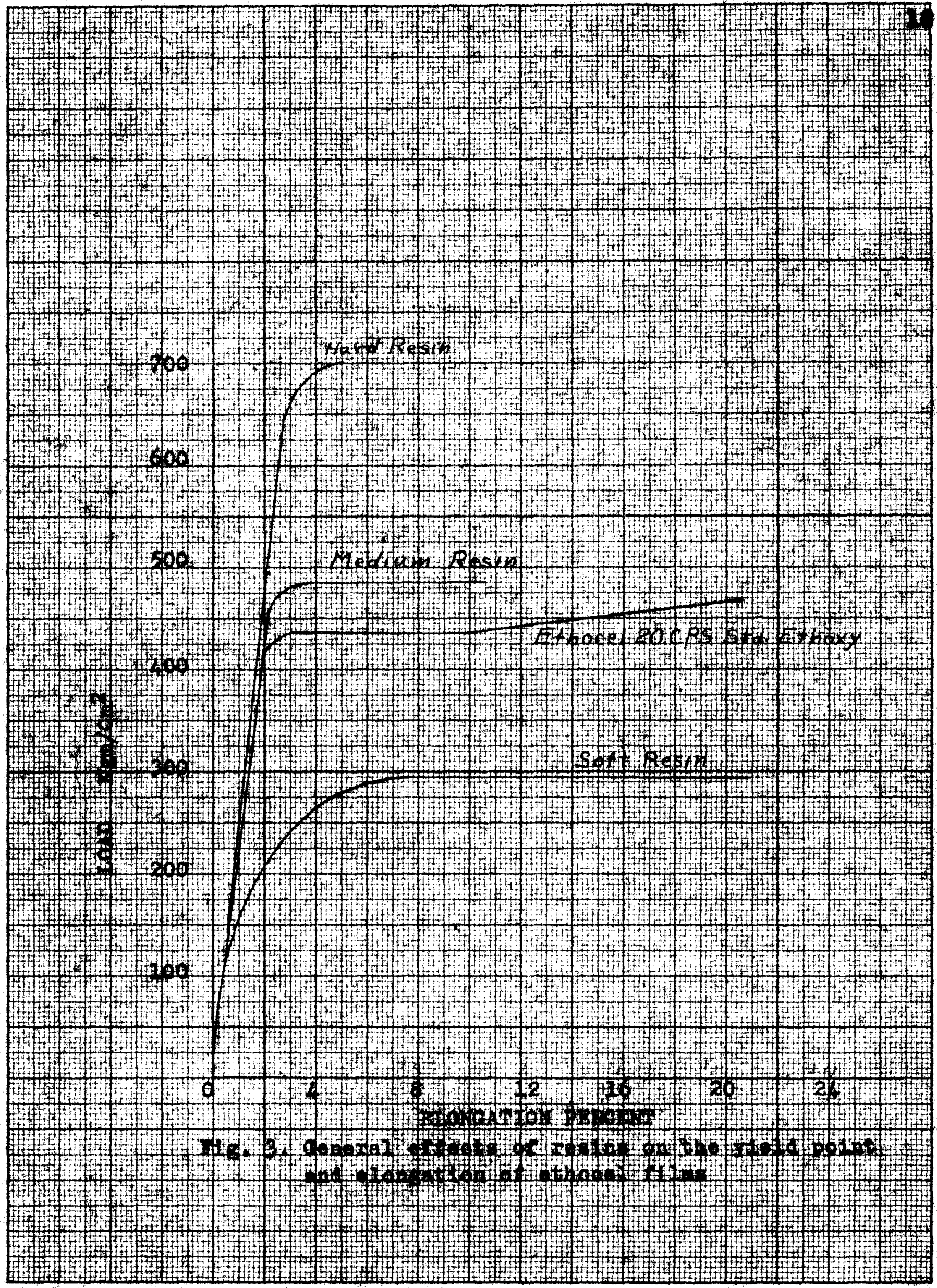


Part 1010 shape 10 another faetor that affeots the phyaloal propertios of a plgment. Fow ocmmerelel plements are unlformy ephorioal, and mang are platelike or aoloular (20). Following 1s given an acoount of the charaoteriotice and beharier of the rarlous pignent used in this study. The most important pigmont is titanium dioxide plgment, The most outetanding property of titanium doxide is its extrome opaolts, whioh is muoh higher than that of any other white plenent. It has apeolfio gravity of 3.9 , and an arerage moan particle size diamoter of 0.3 mierons. It is nonreactive with rirtually all types of rohicles or medis in whioh wite pigments are used.

In small proportions, it has been found to improve elenetiolty, continuity and gloss of collulose litrate flins produced (16).

Baysted $\left(\mathrm{BeSO}_{4}\right)$ is one of the beeviest plgments know. It has mall amounts of Ouso and $\mathrm{Fe}_{2} \mathrm{O}_{3}$ as impuritios. It: spec1e10 gravity is 4.476 and ito arerage partiole alze 1s 2 to 5 alorons. It has no covering powes, very low 011 abeorption, and relatively low bulking ralue. It is inert to the varnish or palnt constituent usually employed.

Lithopone ( $\left.\mathrm{BaSO}_{4} \mathrm{ZnS}\right)$ 1. transparent and has an oxtromely low tinting strength; henoe it makes on oxcellent bese for both colored and white pigmenta. It is atable towards alralle and aelds. It has high apoolflo gravity, 
low bulking power, and low o1l absorption.

China olay (Al $\left.\mathrm{O}_{3} \mathrm{2S10}_{2} 2 \mathrm{H} 2 \mathrm{O}\right)$ is a wite powder of lamollar shaped particlea of extremely fine, and sort texture. It has a secifle gravity or 2.6 and perticle size varying from 2 to 10 mierons. As indioated by 1 ts specifio gravity, china olay is a very bulky material; however 1ts covering power in oll or varnish vehtole is poor. Its 011 absorption varies onnsiderably and is dependent to a great extent on partiole s1ze. It is quite permenent to light and not affected by elther ac1ds or alkalls.

Santocel is light welght, flnely divided, porous form of 811100 produced ohemioally from s1110a aerogel. S111ca Nerogel differs from the conventional silloa gel principally in the avallability of 1 ts surface and its dry bulk density. It is not hygroseopio, the liquid phase having been removed without otherwise altering the struoture of the aerogel. Alr replacen the liquid removed glving a struoture much like that of unoompreseod sponge.

Santocel is made of sub-ultremicroscopic fibers of s1lice having a dameter of about 25 to 35 anget roms spaced about 300 angetroms apart and arranged similarly to flbers of cotton in cotton batting. The alr volume withIn the particle 18 about 94 percent. The true specifle gravity of santooel incorporated in a vehlele is the same as any other form of silloa, namely 2.2. The specifio surface of santooel is high, being on the order of 600 
square meters per gram, and the surface is somowhat notive. This huge surface comblined with the porosity acoounts for. the high oll absorption whioh cannot be measured by conventional means. The refractive index is equel to 1.464 .

Bentontte is a clay contalning for the most part "montmorillonlte." The montmorilionite clay moleoule has two sllicon-oxygen sheots with one eluminum oxygen sheot sandwlohed between them. Because of thls pecullar molecular struoture and fineeness of partioles, bentonlte olay goes into a oollo1dal suspension In water wh thout the use of any physloal means. However it ahould be noted that bentonlte clay partioles bocone energized only when wetted. Bentonlte. andysis showe the presenoe of seall imporities of 1ron, magnotla, 11me, soda and potash.

Dicollte material has been known by many namos, among whioh infusarial earth, keisalgohr, diatomite, diatomaceous earth, and diatomocoous alloa are best known. DLatomacous allica has been preferred as the most truly desoriptive and more nearly the correot teohnioal and ohemieal deslgnation. Dicallte welght only 19.6 pounds per ouble foot. Surface area is extremely large, rangting from 3,000 to 5,000 square feet per pound. Absortiveness is high. It is chemloally Inert, physically it is amorphous in oberacter, soft and friable. It is heat resistent and has a high infra red rerlosteseo, but it produces a dead flat finloh with no angular shoen. 
Inotead of beling approximately spherieal or otherwise folrly uniform in shape, the vierosoopio partioles of Diatomacous elliea are nore $11 \mathrm{kelg}$ to be long and alender, "boat shepod," "flaky," or "dimooid." 
BXPERTMENTAI 
DEUIS IagRTINO FOIMT APPARATUS

This inctrumont was dosigned for doternining the wolting polnt of a great varioty of naterialo at any terperature rros 25 to 200 degree entigrade. It conformed in prinotple to the apparatul orletinily proposed by Dr. L.H. Denis of Cornell valversity.

The hoted stage of the Deal. apparatue convisted of bay of copper, one Inoh equare and 17 inehes leag, heatod of an elcetrie cartride ineerted inte ono ond. The temperature of any point along the top earrace of thle bar way

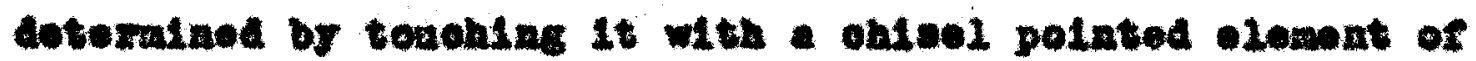
heary constentan wire. The thexeooouple developed at the

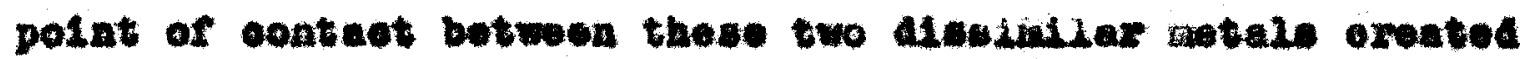
an e.m,f. Whioh was proportional to the terperature th that

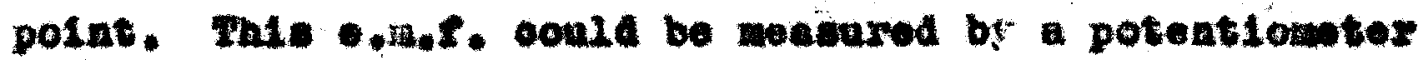
-1reatt. As the bar wo beated at ono end only there was a

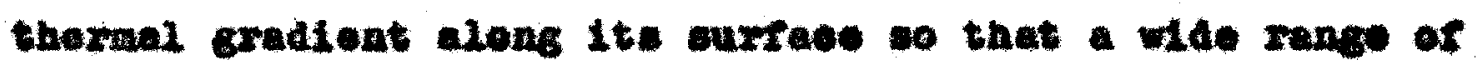
tempereture could be obtalnod. If the laoguer r11m wa lald on the bax, portion would molt, and the reat would conatet

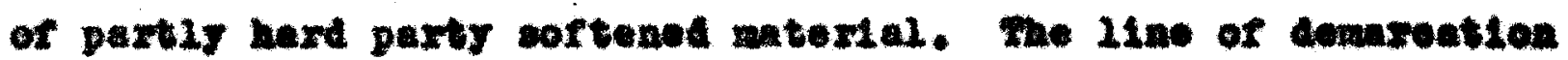
between the sortened and the medted fin conotituted the aditing polut of the film (10). Scotr IENSIII-TESTRA

soott-ronsile zeoter conviated of a vertioel eteel rod about one lah in alameter aupported on havy bece. 
On top of this rod was a clamp carrying a shaft through it having a movable segmental soale attaohed to 1t. Tho scale was divided into two parts, one part ranging from 0 to two pounds. This was to be used for woak fllme while the other soale ranged from 0.0 to 10.0 pounds and was to be used for atronger fllms. A 10 pound welght was atteched behind the 80ale. The soale had "catoh" whloh with the help of a ratchet and pawl arrangement let the scale move in eront of a flxed polnter in one direction only.

Attaohed to the same shaft that carried this soalo was a pulley arrangement on which was balanoed a welght on one slde and a olamp on the other whloh was used for holding one end of the film. Below this olamp there was another sinilar clamp attaohed to gear and"olutoh" arrangement, so that it oould be moved up and down freely if neossary. Th1s olamp was conneoted to the pulley in suoh a way that It mored down with a certain desired speed on connecting it to the motor by the help of the elutoh.

As the lower clamp moved down, it pulled the upper clamp by way of the filin and thus the segmental soale tilted pushing the 10 pound welght upward exerting a unformly increasing welght. A vertioal scale in millimeters was prorided next to the film so that the elongation oould be measured. As soon as the film broke, the segnental soale would stop morling, and the reading in pounds oould be read direotly. 


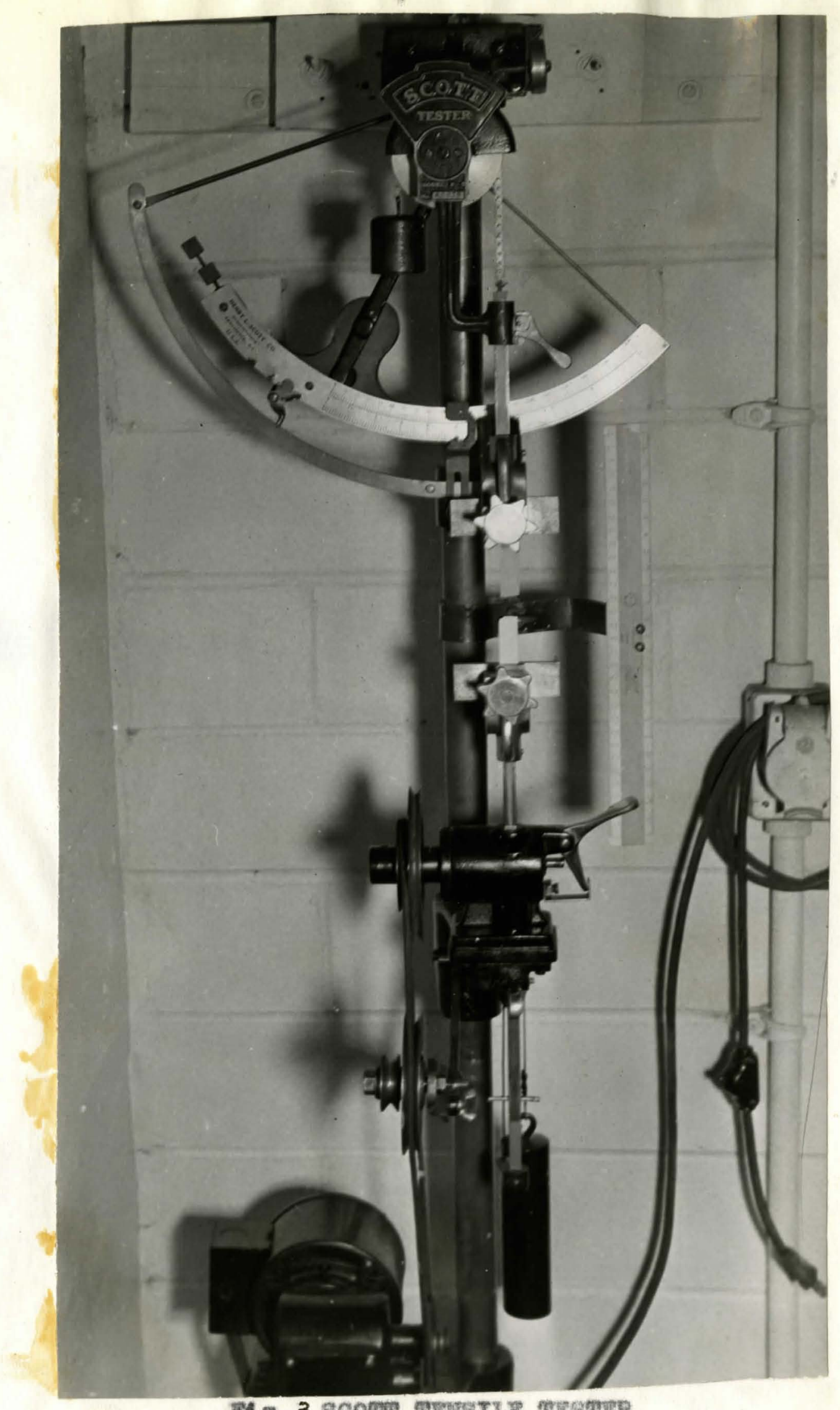

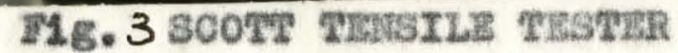


MATERIALS USED

Ethyl aloohol. Speoifto gravity 0.798 Bo1ling point $80^{\circ} \mathrm{C}$

Toluene. .speolflo gratity 0.865 Bolilng point $110^{\circ} \mathrm{C}$

Resin .276 - V9 Dow Resin

Sodium dichromate .Cormercial

Bthocel - (Dow) Standara

Ethoxy content $48.58-49.58$

Solub1lity--free of haze and Branularity in a $20 \%$ solution in 80:20 TolEthanol

stab111ty-more than $90 \%$ retentention of orlginel Tsoosity after 16 hours heating in a closed ressel at $120^{\circ} \mathrm{C}$

Molsture content ........... less then 2.0\% Ash content ...............10ss than $0.15 \%$

Chlorides (as rasl)........ less then $0.05 \%$

Phystoal form ............ treo-slowing whise granules PICMRMms

1. Santooel - No. 45 Monsanto Chemioal Co.

2. Bentonite olay No. 290 American Colloid Co.

3. China olay 
PIGMENTS (cont'd)

4. Celite $165 \mathrm{~S}$ or 110 Johns Manville Co.

5. Dicalite " $L "$ grade, Dicalite Company

6. Barytes, Kentucky Color and Chemical Co.

7. Lithopone

8. Hitanox

Solvent Composition

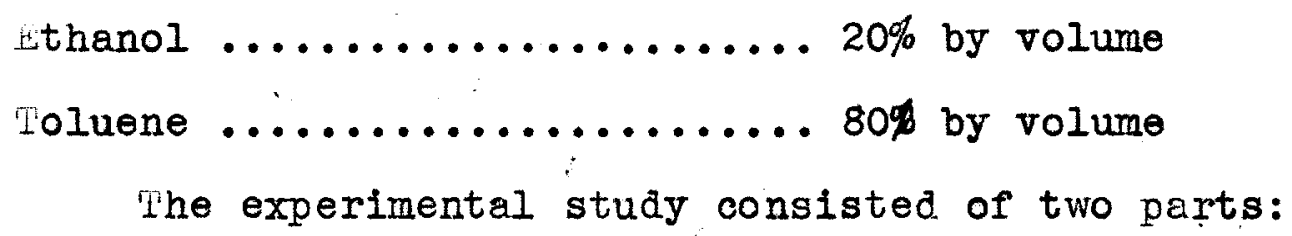

First, the determination of the softening and melting points and second the determination of tensile strength and percent elongation at the breaking point of ethocel films containing pigments.

It was decided that lacquers would be prepared containing 75/25. Ethocel 276-V9 Resin in 80/20 toluene/ ethanol. The above mentioned fillers or pignents were to be ground or ball milled into the se lacquers in the ratios indicated below: $1.0 \%, 3.0 \%, 5.0 \%, 20.0 \%, 50.0 \%$ pigment.

These lacquers wer to be cast to give a film of approximately two mils ary thickness. The flim was to be air dried for at least two hours and then dried at 70 degrees centigrade for two hours. After conditioning at $50 \%$ relative humidity at 70-75 degrees $F$ for at least twenty four hours it was to be cut into testing strips and the following data 
were to be obtalned:

1. Sortenling point and melting point.

2. Peroent elongation at breaking point.

3. Tensile strength in kfliograms per square on.

The softening and melting points would be deter-

mined by means of a melting point bar. Percent elongation and tensile strength should be deternined by a soott rensile Teeter.

The flrat step was to prepare a test samplo of the leoquer which oould be oest into film of two mils dry thiokness. The caster or the doctor blade oould be manipulated to lay a wot $112 \mathrm{~m}$ from $1.0 \mathrm{mils}$ to $50 \mathrm{mils}$ thiokness. The f1lus were lald on 12 by 6 inoh glase plates, haring unifom surfeoe. Before the filme were lald, the glase plates wore soaked in ohronto acld solution, washed thoroughly with warm water and dried under oover, so that no dust partioles oould get on the surface of the plates. Usually, plates were left overnight so that oemplete dryness oould be invured. Film were then oast over the plates with the laoquers propared.

The laoquers were prepared in a glass bottle of $500 \mathrm{ml}$. oapaelty, and enough solvent was aded to dissolve the wollds so that there was no need to heat the laequer. shaking or rolling the bottio on the mixing rolls aehieved this purpose. The whole mass was allowed to rest unt1l all the al' bubbles had escaped. 
By repeated trials, it was found that 4.0 gon of solvent per ga. of sollas was a little orer the minimum monnt of solvent that would give smooth and evenly moring laoquer under the f1lm oaster. The ary thlokness of the I1In could not be prodioted from the wot thiokness honee a nubber of Illms were laid with wet thlokness varying from 20 to 25 mil. Films were allowed to dry on the glass plates for two hour at roon terperature under oover, removed from the glass plates, and conditioned for twenty four hours at a. 50 27 relative humidity and temperature of $70 \pm 3$ degroos $\boldsymbol{F}$.

The films depolited were about 11.0 on wide and 0.0020 .0005 inches thiok. At least four strips were out from each IIIn with razor blade using a reotangular template 0.5 1nohes wide. The test atrips were clamped in a soott Tene1le Fester so that the length of the IIIn between the Jaws was 3.90 1nohes. With the $5 \mathrm{rgm}$ welght on the load arm, the lower jaw was pulled downward unlformy at the rate of 25.4 m.m. per minute. As the film was pulled down, it lifted the wolght on the load arm, an orer lnoreasing load being applied. The elongation was read diroot from a seale craduated in milliwaters. The wolght in pounds at the jield polnt was read from the soale and tens1lo at rength computed in row/eq.en. The thicknoss of the film was mosured at rarious plaoes, and it was bellored that the film would yield at the point of least thlokness. 
After the tost samplo had been subjeoted to the Seott Tester the thlokness at the jield point was again measured by "Randell-8t10knoy" measuring gauge, and the thlokness oheoked with the previous value noted. These two values usually affered sllghty. The thiokness arter the test was usually less then the orlginal thlokness due to an elongation of the Fllm. However sonetimes, ountrary to all expeotations, the film thickness at the rield point we round greater than the miniman thlokness observed preriouly. This condition might be the result of some Inherent defeot of the film, eauling a weakness at that apot. Suoh samples wero dsoarded. At least four readings were taken to determine the Tenuile Strongth and the yield point of the rilm. Host of the time the readings aid not agree beeanse of the error in the Soott-rondile Tester, whioh has been estimated by some workere to be from 5.0 10.0 peroent.

Sortening and melting points of the rilns were deterratined on the "Donnis-Bhelton" melting point bar as deseribed protiously. The film was latd down in the middle of the hot bar. After thirty seconds one end of the film lying orer the ooler side of the bar wa lifted and pulled upwards, unt1l elther the whole of the film oame off the bar or a part atuak to the bar, und part broke off. The temperature of the bax at the polnt where the rilm broke was moaaured imedately by moans of a thermooouple on a sliding arm, 
as desoribed before and gave the melting point of the film. The temperature at the polnt where the film became plastio and started to ahere slightly to the bar was also measured as the ortening point of the $\mathrm{fllm}$. Four readings were taken for each $\mathrm{ILIm}$ and mean value was recorded.

The experiment was conduoted at room temperature.

The softening point could not be measured ecourately as no speolfio Indication of the plasticity of the f1le could be observed. The riln would not become plastic at any one spot; the softening extended over an area of about four square on. The boundary line could not be observed clearly; hence the softening point was determined approximably and was taken at

a point where the film seemed to beoome plastio as well as adhered slightly to the bar. 


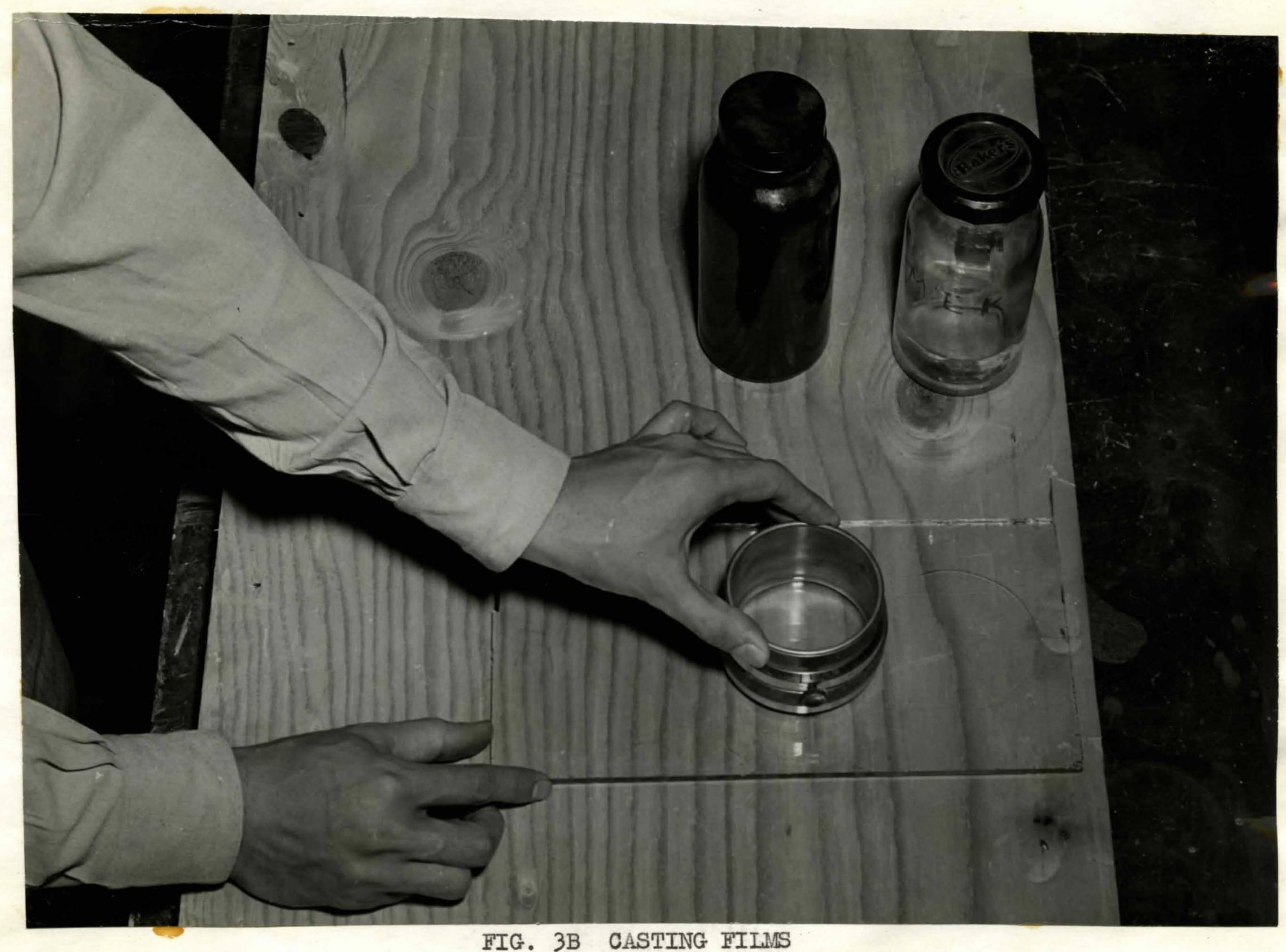


INCORPORATION OI THS PICAENTE

Tho plement was wolghed acoording to the percentage roquired and was put into a bottlo of $250 \mathrm{ml}$. oapaoity, opecially selected because of 1ts thlok walls whioh would withstand the poanding and grinding eotion of the steel balls. A I1xed number of steel balls of different s1zes was put in with the laequer and the bottio was put on mixing rolle. This miling and grinding was carrled out for twenty-four hours and the laoquex was oast on olean glase plates with the Dow IIIm saster. Here again the diffloulty arose that there was no relation between the ory f1ln thioknoss and the wot IIIn thlokness, honoe the wot filn thiokness had to be attempted a fow times before the required 11In was made. However, arter working with these filme for sometine, faolilty was aequirod, so that a satiaractory wot thlokness of the film could be prodioted to get a filn of two mils dry thlokness, But because of the differenos in apeolf10 gravity, oll absorption, and bulking values of the different terials, use of this torecasting teohnique was not whout its fallures. The rate at whloh the cating blade was moved had to be standardized beakuse it was obcorved that the thiokness of the 112n was Interwely propertlonal to the opeed with which the dootor blade was roted on the glase plate. This was espeeialiy true when the amount or laequer used was less then $\$$ Inoh deep in the Dow Caster oup. Honoe, a certaln upoed was hit upon and, all the films 
were laid at that speed. The wot rilms were allowed to ary for two hours, remoted from the glase plates and dried in alf for an hour. Remoring the rilm from the glass plates was found to be diffioult and roquired special oero and tech alque; however, it was findily acoomplishod; Covering the f1lms with warm damp oloth greatiy faolliteted the removal of films. These filme wore then suepended in amall electrie oren maintalned at a temperature of $70 \pm 3$ degrees $c$. The f1lm always beoame plastio and deformed therefore, the oten arying procedure had to be changed. After some experimentation it was observed that if the texperature was sowly ralsed for two hours, this doformation of fllms oaused by premature sortenling aould be avolded. In all the determinations, the abore prosedure of arylng was followed. These dred films were thon placed in a oonstant humldty ohamber and kept a temperature and relatire humidty or $70 \pm 3$ degrees $I$ and 50 peroent respect1tely. Fllme were conditioned In this chamber for twonty-four hours, then removed and out Into strips one half inoh wide by the holp of aharp razor blade and ateel template. Tensile strength, peroent - longation, sortening point and molting polnt were then dotermined as desoribed before. To Ingure that the aletribution of the plenent was unfform in the laequer, all filns were examined under a mleroseope, and any samplee with an uneren plement distribution were disonded. In somo oases(eantoeel) it was observed that the 
amount of plgment exoeeded the limit, and agelomeretion of the plgment took plaoe in the film. These rilms could not be used for experimentation, end no results could be obtalned Por suoh f1lms. 
DIsCUBsTon of REsULRS 
Whe results obtalaed are presented in table I. Only the maxtmon tonel1e otrongth, highost cortening and molting: pointe and the marimusereent olongation are prowented.

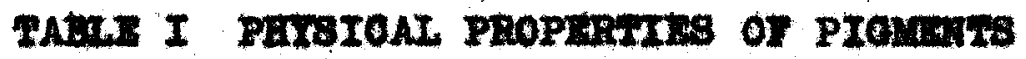

\begin{tabular}{|c|c|c|c|c|}
\hline Pranex & 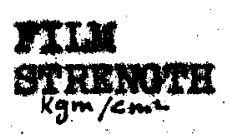 & 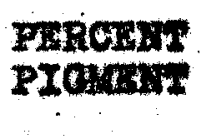 & $\begin{array}{l}\text { sorminxus } \\
\text { Porris or }\end{array}$ & $\begin{array}{l}\text { Propaty } \\
\text { Prontin: }\end{array}$ \\
\hline Ethooel & 317 & 0.0 & 77.0 & 0 \\
\hline Atsanox & 425 & 1.0 & 92.0 & 2.0 \\
\hline If thopene & 350 & 3.0 & 91.0 & 20,0 \\
\hline Barytos: & 326 & 3.0 & 83.0 & 10.0 \\
\hline oltse & 313 & 1.0 & 108,0 & 50.0 \\
\hline Deallte & 368 & 5.0 & 93.0 & 50.0 \\
\hline Entooel & 299 & 3.0 & 83.0 & 10.0 \\
\hline Bentenite & 309 & 1.0 & 98.0 & 50.0 \\
\hline onina elay & 313 & 2.0 & $\rightarrow$ & $-m$ \\
\hline
\end{tabular}

\begin{tabular}{|c|c|c|c|c|}
\hline Prouext & $\frac{\text { moxtrat }}{\text { potan }}$ & $\begin{array}{l}\text { PERomir } \\
\text { Ptevitir }\end{array}$ & 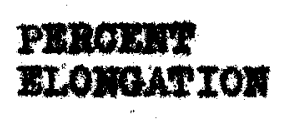 & 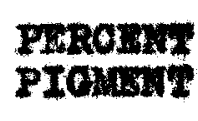 \\
\hline Ithoed & 92.0 & 00 & 5.9 & 00 \\
\hline Itanox & 104.0 & 3.0 & 9.0 & 5.0 \\
\hline Lthopene & 105.0 & 50.0 & 6.25 & 3.0 \\
\hline Darrtes & 101.5 & 10.0 & 8.19 & 1.0 \\
\hline oedtto & 232.0 & 50.0 & 6.25 & 2.0 \\
\hline DLeal1 to & 221.0 & 50.0 & 6.86 & 5.0 \\
\hline Santoed & 102.0 & 3.0 & 5.20 & 3.0 \\
\hline Bentonite & 115.0 & 50.0 & 6.25 & 3.0 \\
\hline
\end{tabular}




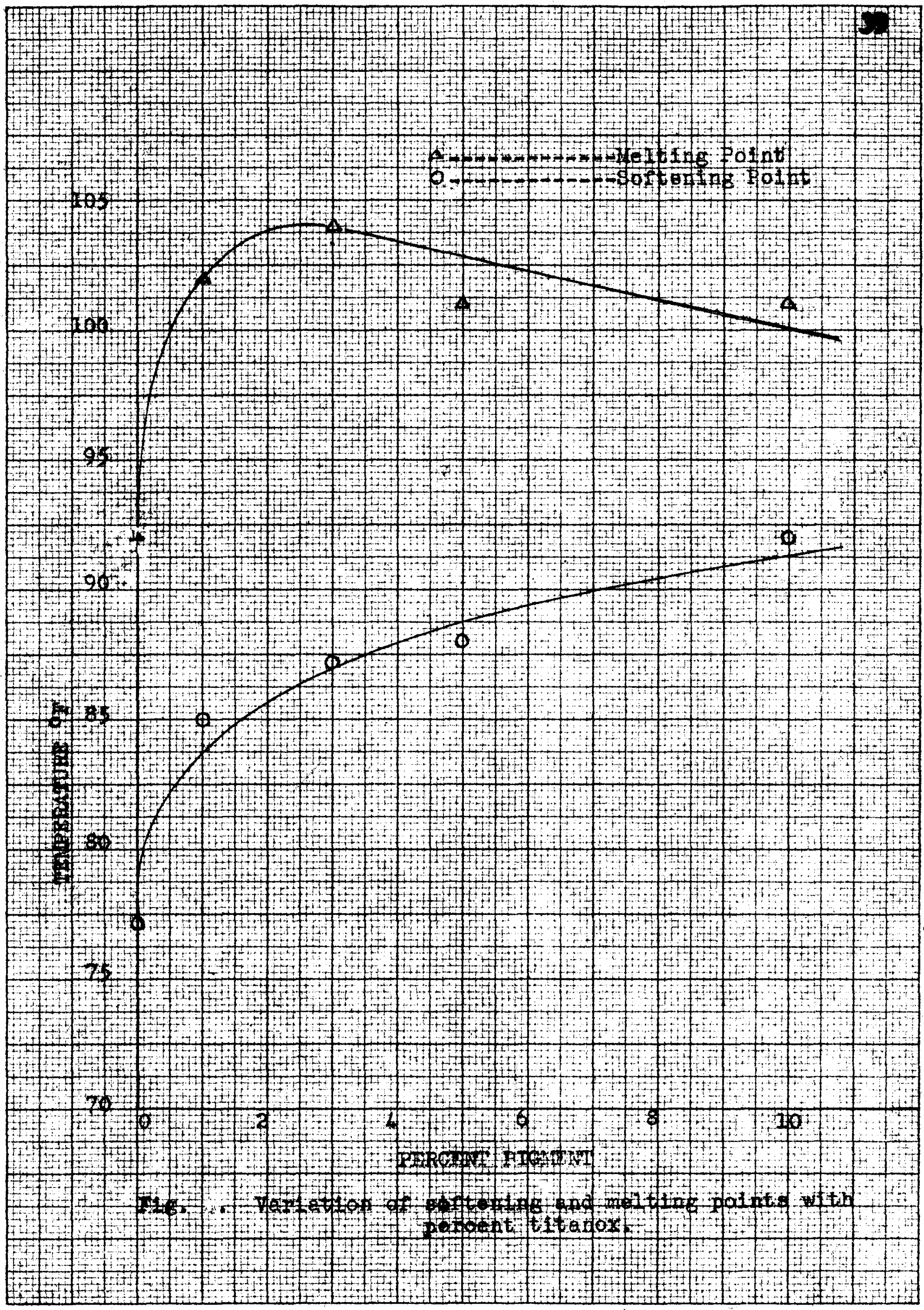




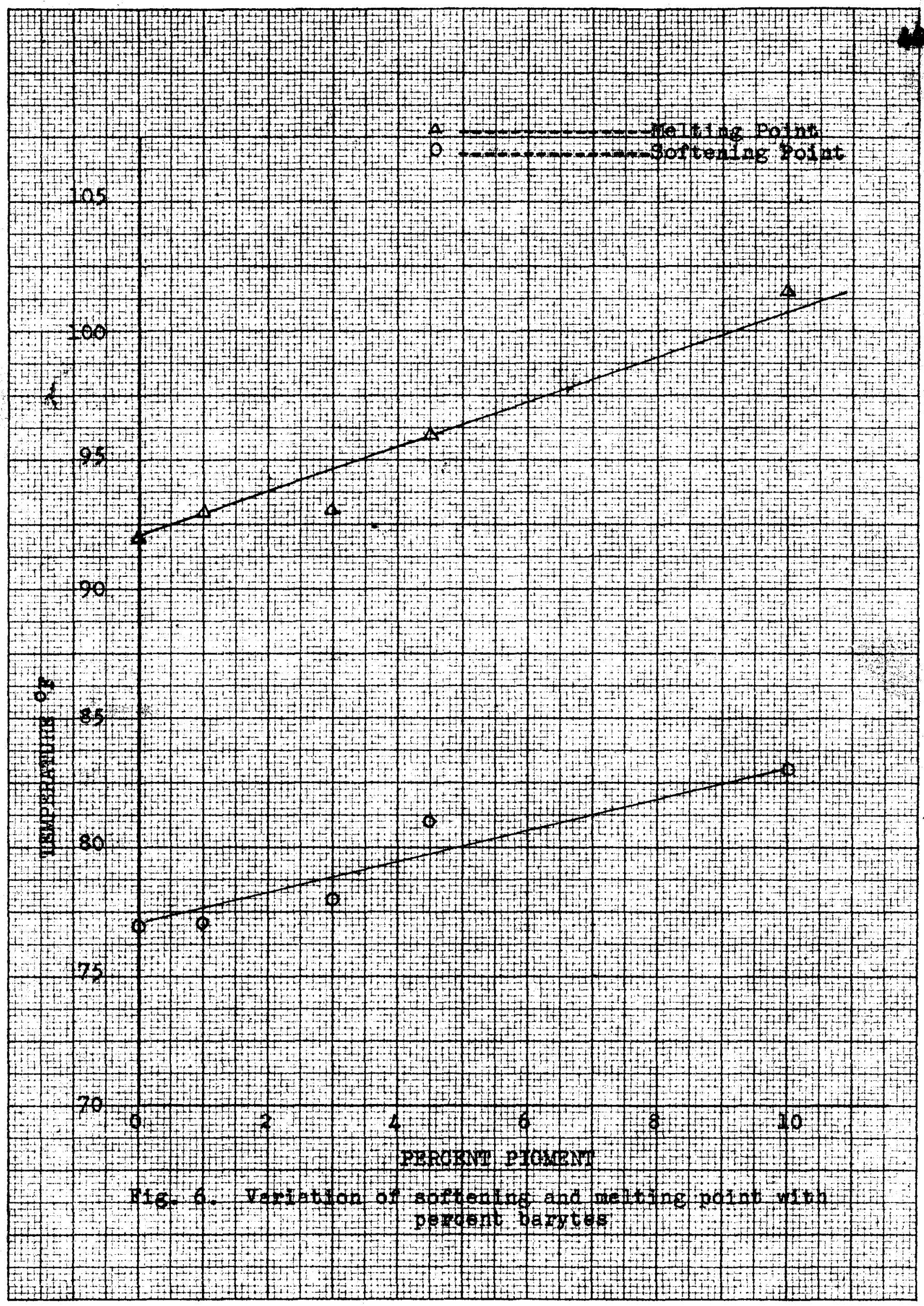




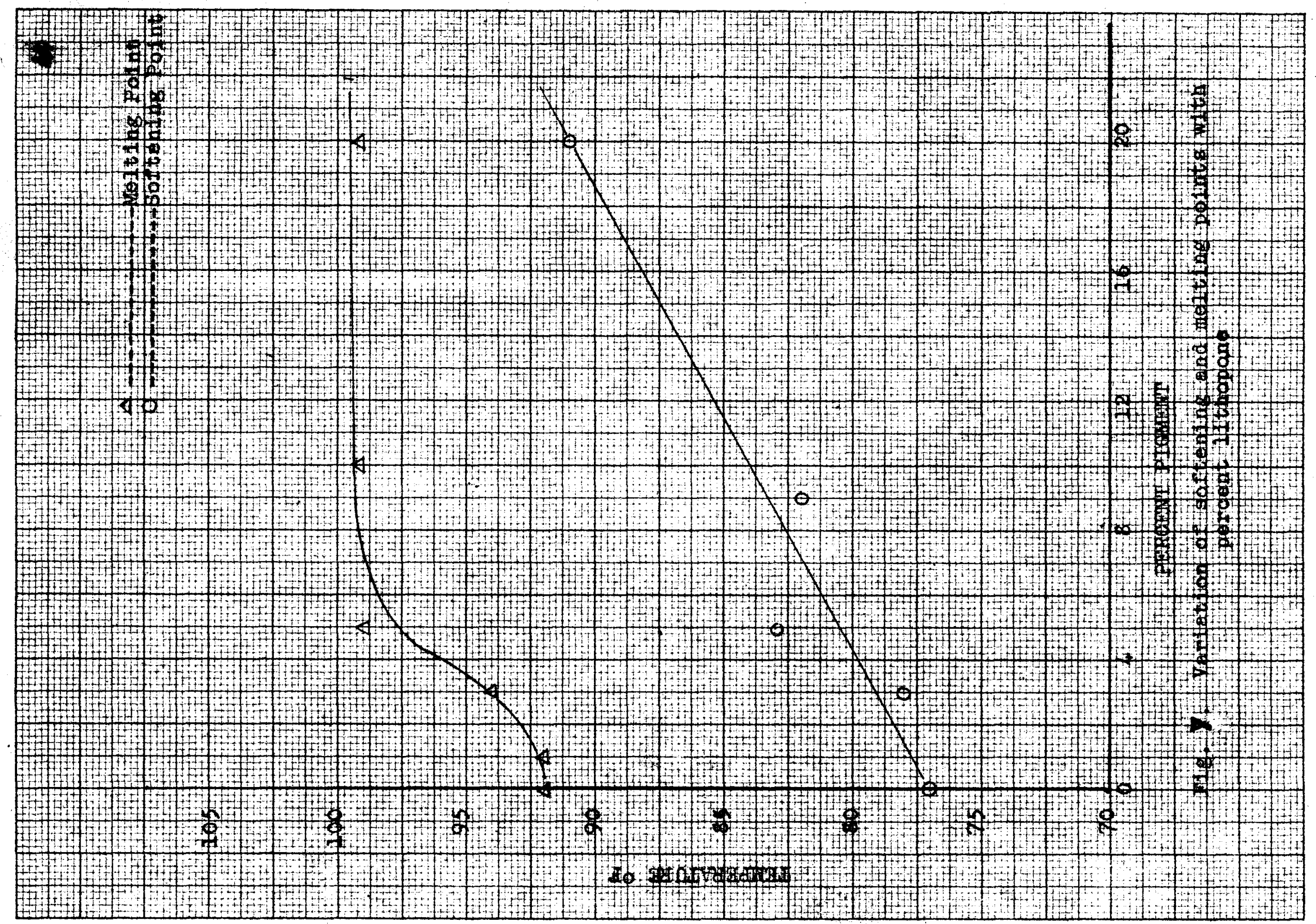




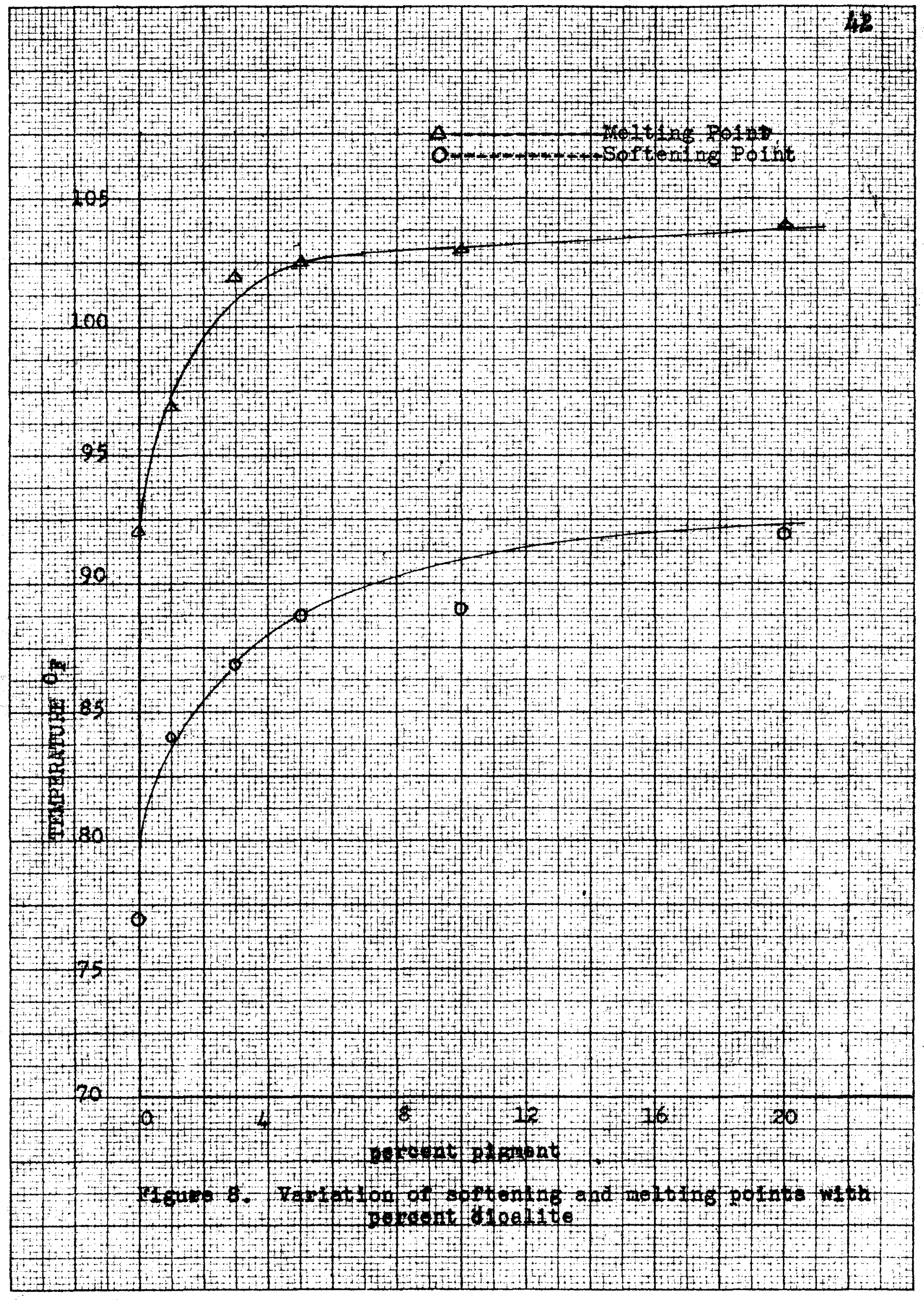




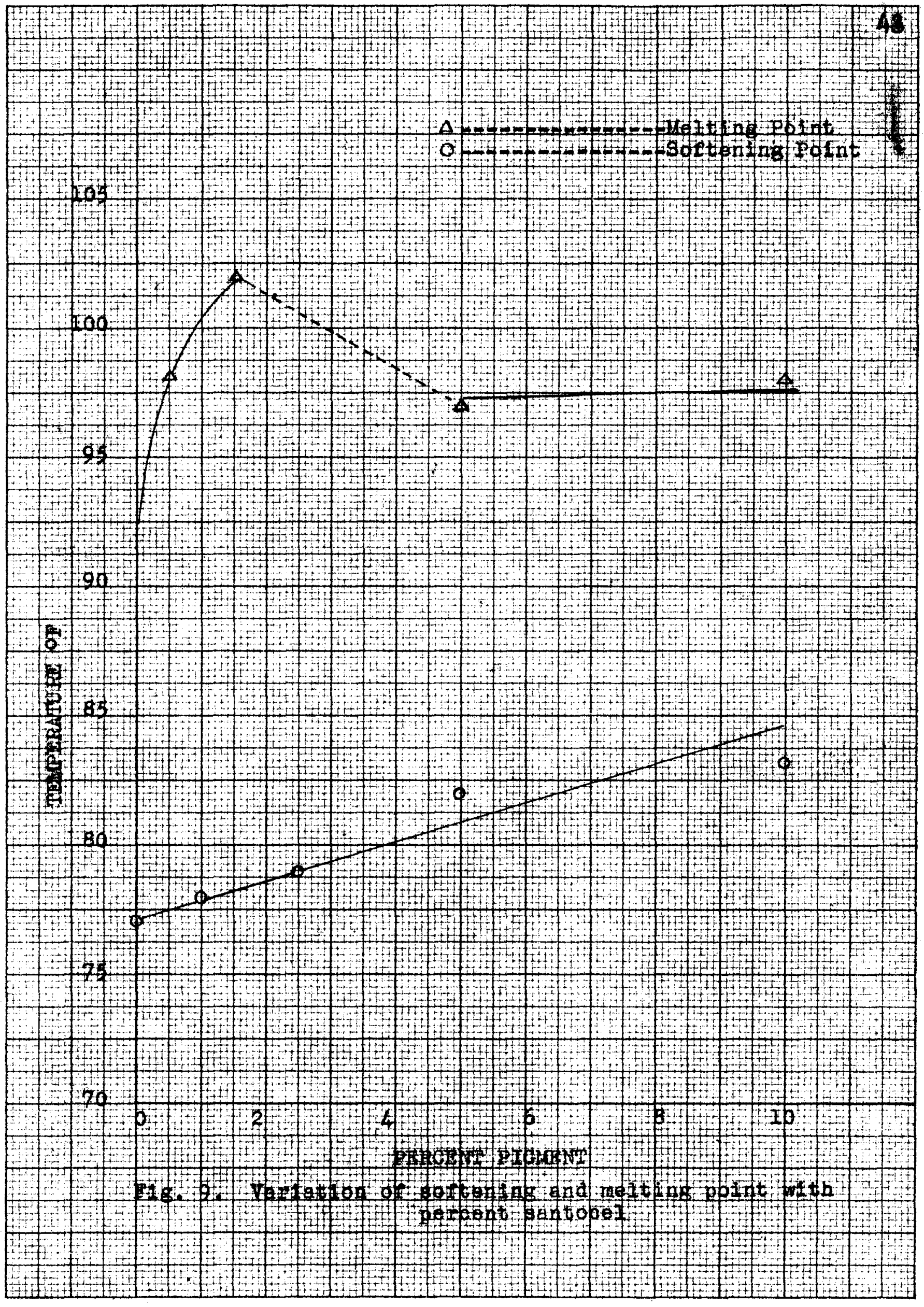




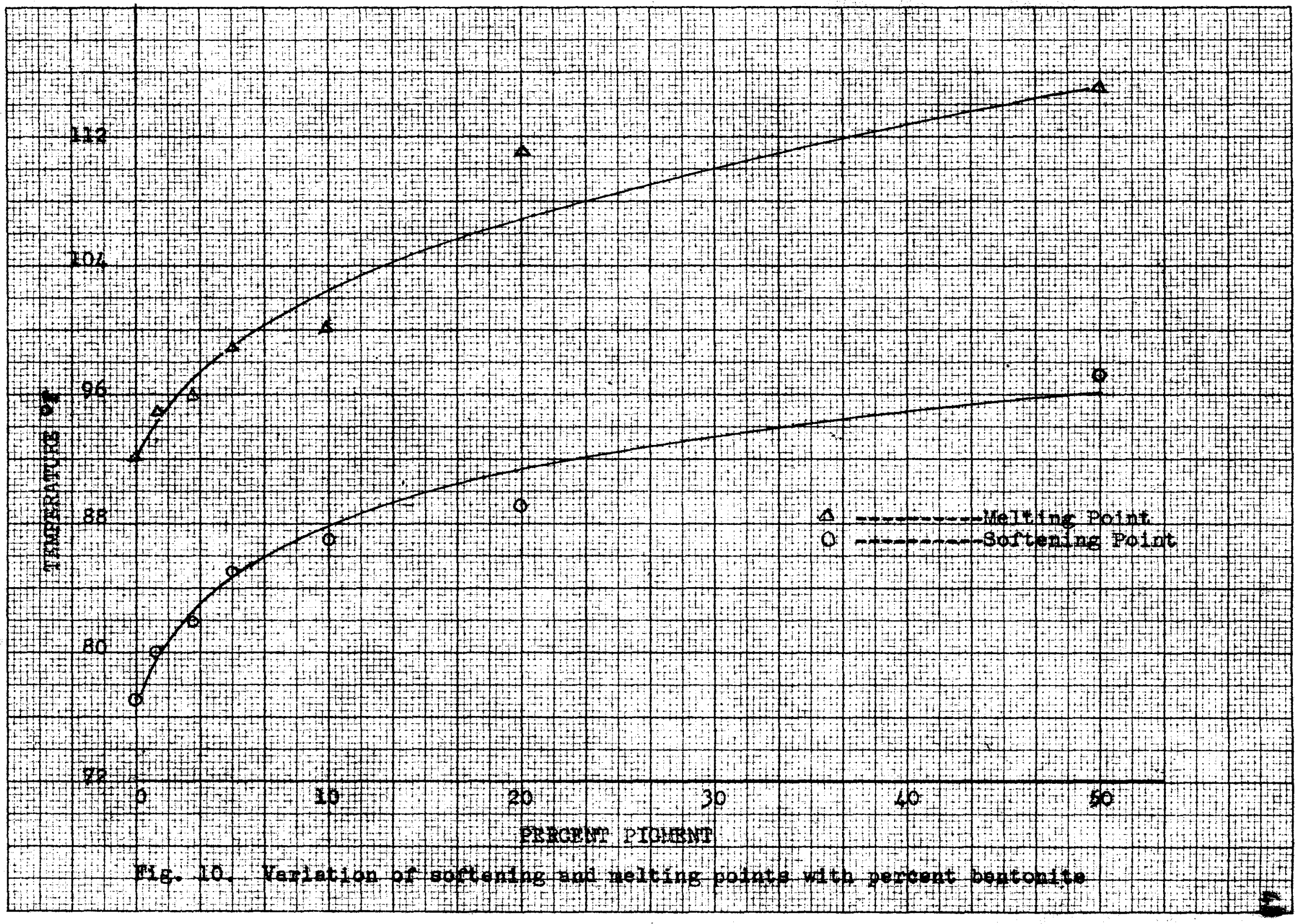




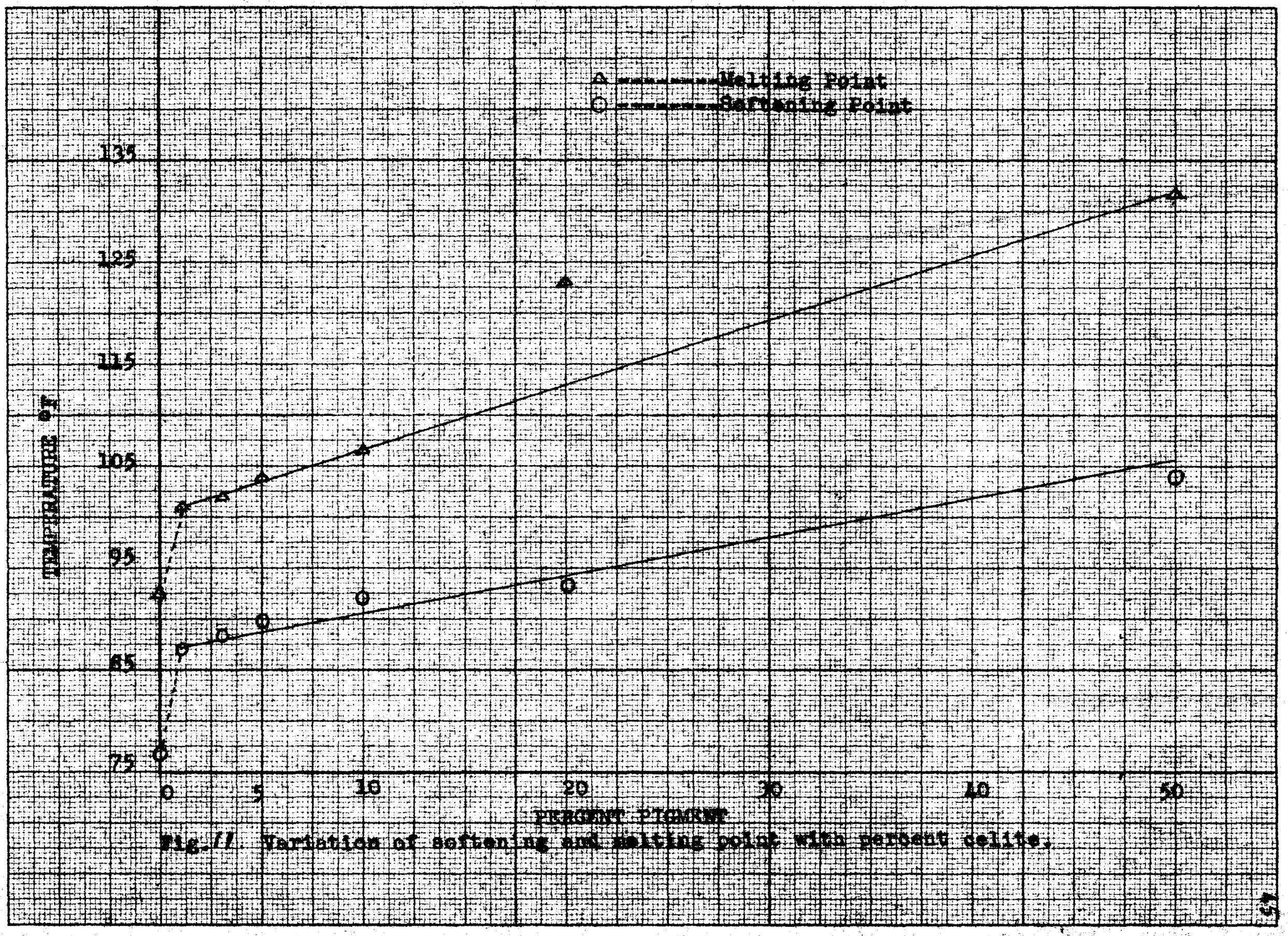

Pan 


\begin{tabular}{|c|c|c|c|c|c|c|c|c|c|c|c|c|c|c|c|c|c|c|c|c|c|c|c|c|c|}
\hline & & & & & & & & & & & & & D 1 & 15 & 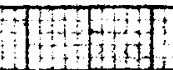 & 8 & & & & & & & & & \\
\hline & & & & & & & & & & & & & DII & IIt & & & & & & & & & & & \\
\hline & & & & & & & & & & & & & ind & & & & & & & & & & & & \\
\hline & & & & & & & & & & & & 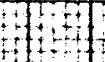 & tit & & & & & & & & & & & & \\
\hline & & & & & & & & & & & & & $4+4$ & & & & & & & & & & & & \\
\hline & & & +4 & & & & & & & & & तI & & 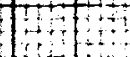 & & & & & & & & & & & \\
\hline & & & & & & & & & & & & & & & & & & & & & & & & & \\
\hline & & & & & & & & & & & & & & & & & & & & & & & & & \\
\hline & 500 & & & & & $1+t_{t}$ & $\therefore$ & & & & & 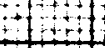 & & & & & & & & 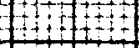 & & & & & \\
\hline & & & & & & 4 & in & & & & & & & & & & 4 & & & $1+1$ & 01 & & 4 & & \\
\hline 4 & & & & & & : & & & & & & & & & & & 4 & & & Af & $1+4$ & & & + & \\
\hline$\phi$ & & & & & & & & & & 6 & & & & & & & 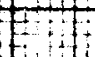 & & & & & & & 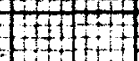 & \\
\hline 7 & & & & & & & & & & & & & & & & & & & & & & & & & \\
\hline * & $40 \%$ & & & & & & & & & 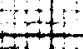 & & & & & & & & & 4 & & & & & & \\
\hline 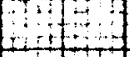 & 4 & . & 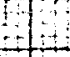 & & & A: & & if & & $4=$ & & $\therefore$ & & & & & +1 & 3 & & & & +4 & $5+$ & + & \\
\hline+4 & 1 & & & 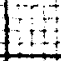 & 1 & $1 \pm$ & & & & +4 & & 15 & $\square+1$ & & & intit & & it & & $4=$ & 4 & $\mathrm{H}_{\mathrm{E}}$ & $4+4$ & +4 & \\
\hline & A & & 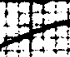 & $t$ & T7 & 17 & & in & $+t$ & Dtth & & H & $1+4-1$ & & & & 4 & & & 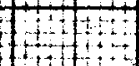 & पt & $4+4$ & $4+4$ & $4+4$ & \\
\hline 4 & +4 & & 4 & $t$ & 4 & 7 & 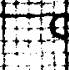 & 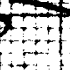 & & +2 & +2 & & +4 & 4 & & 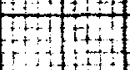 & Wit & +4 & t & & & 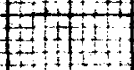 & $4+$ & titit & \\
\hline $1+7$ & & & & $y$ & 18 & & 5 & 5 & & & & & $7+1$ & +5 & it & & & & & H & $1+$ & 7 & & Hit & \\
\hline ift & & & & & & & & & & & & & & & & & & & & & & & 4 & & \\
\hline 䏺 & & & & & & 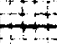 & & & & & & & & & & & & & & 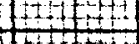 & & & & \pm & \\
\hline 遇 & & & & H & 15 & & & 政 & & & & $1+1$ & & & totet & & 1 & & 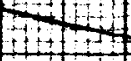 & 4 & 15 & Q & & & \\
\hline 道 & 200 & 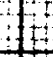 & 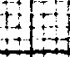 & $E$ & +1 & 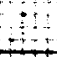 & & 1 & & & & 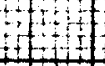 & +4 & 15 & & $4+4$ & 14 & 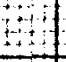 & tis & 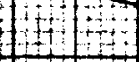 & $\sqrt{4}$ & +1 & $t+4$ & th & \\
\hline fot & tit & & $7+1$ & : & H & +4 & & 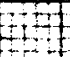 & 7 & 14 & & 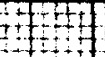 & Fit & Writ: & HII & (4) & tit & 0 & & $4+4$ & & A: & तt & D+ & \\
\hline ftal & tit & & 4 & H. & 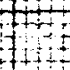 & 15 & & & & $4+$ & & tititit & 4 & 4 & 14 & 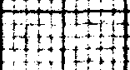 & 4 & & $4 t+$ & $4+4$ & & 84 & tit & $4+4$ & \\
\hline +4 & 19 & 1 & 4 & 4 & 5 & 4 & & tit & & f+7 & & the & t+t+ & $\sqrt{1+2}$ & 10 & $4+4$ & 4 & $4+$ & & $4+1$ & $4+4$ & 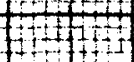 & 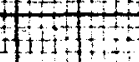 & $4+4$ & \\
\hline & 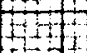 & & Het & 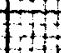 & 4 & 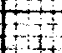 & & itit & & 4 & & + & +4 & D10 & $4+4$ & 16 & & & & $4+1+1$ & & $t+t+4$ & & & \\
\hline & 109 & & & & & + & & & & & & 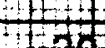 & +4 & & & & & & & & & 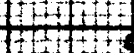 & & & \\
\hline & & & 4 & t? & & & & $w_{4}$ & & & & 4 & $+2+1$ & $170>$ & & 4 & & & & $10+$ & Et & & & & \\
\hline+4 & & & & +4 & & & & & & 1 & & 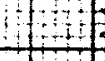 & ESACA & 轿 & IfGlatiz & & Ei: & 4 & $1+4$ & detets & 4 & $+4+4$ & $4+4$ & +4 & \\
\hline & & & & & & & & & & & & $9+4$ & $19+7$ & 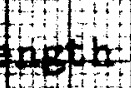 & $9+4 a$ & peq & entat & 7 & Hopog & onat & 4 & 4 & +1 & $4+4$ & $t$ \\
\hline \pm+ & & & & & & & & & & & & $4+2$ & 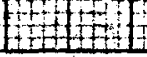 & & & & & & & 进到到 & $1+2$ & 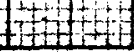 & & & \\
\hline
\end{tabular}




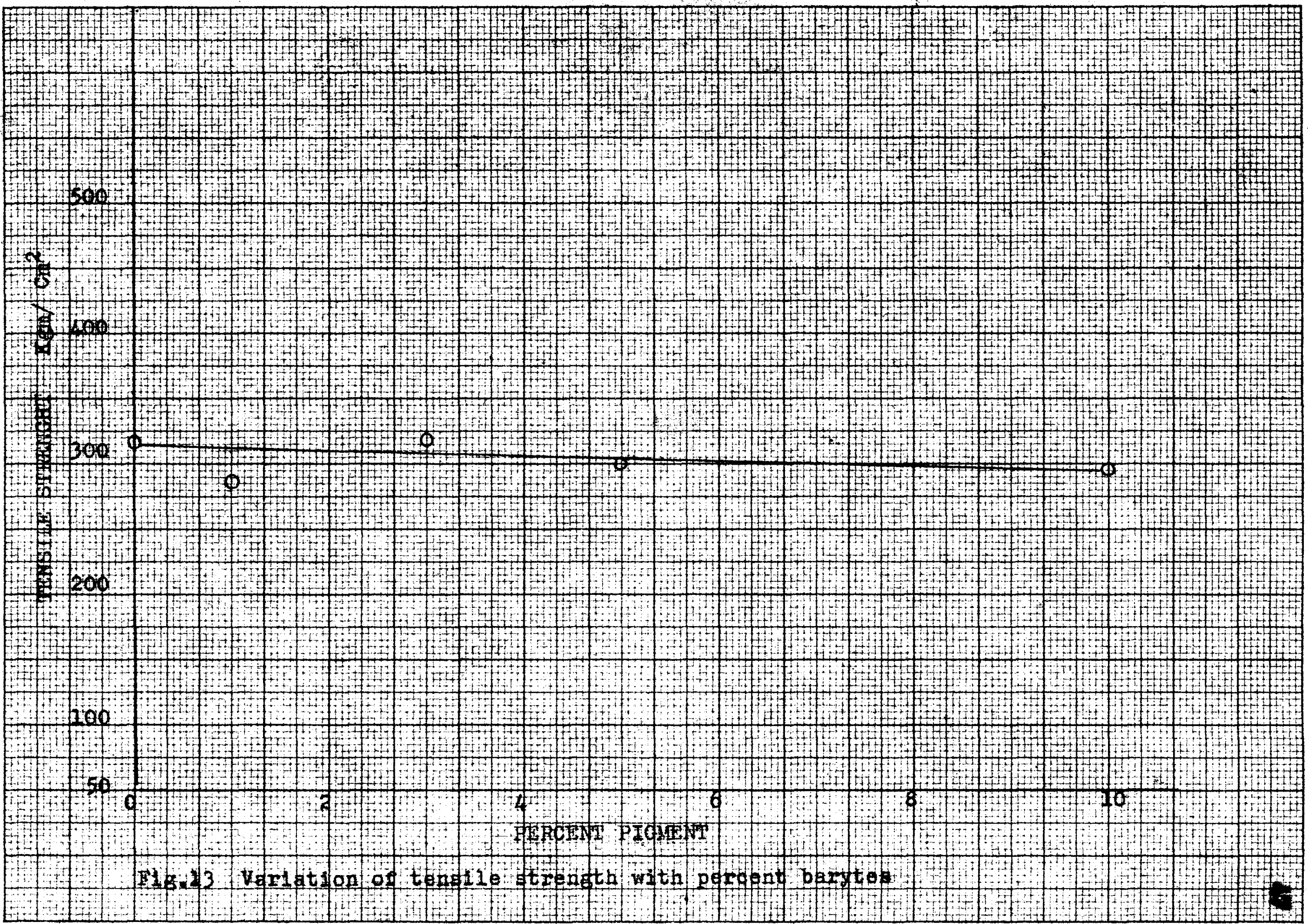




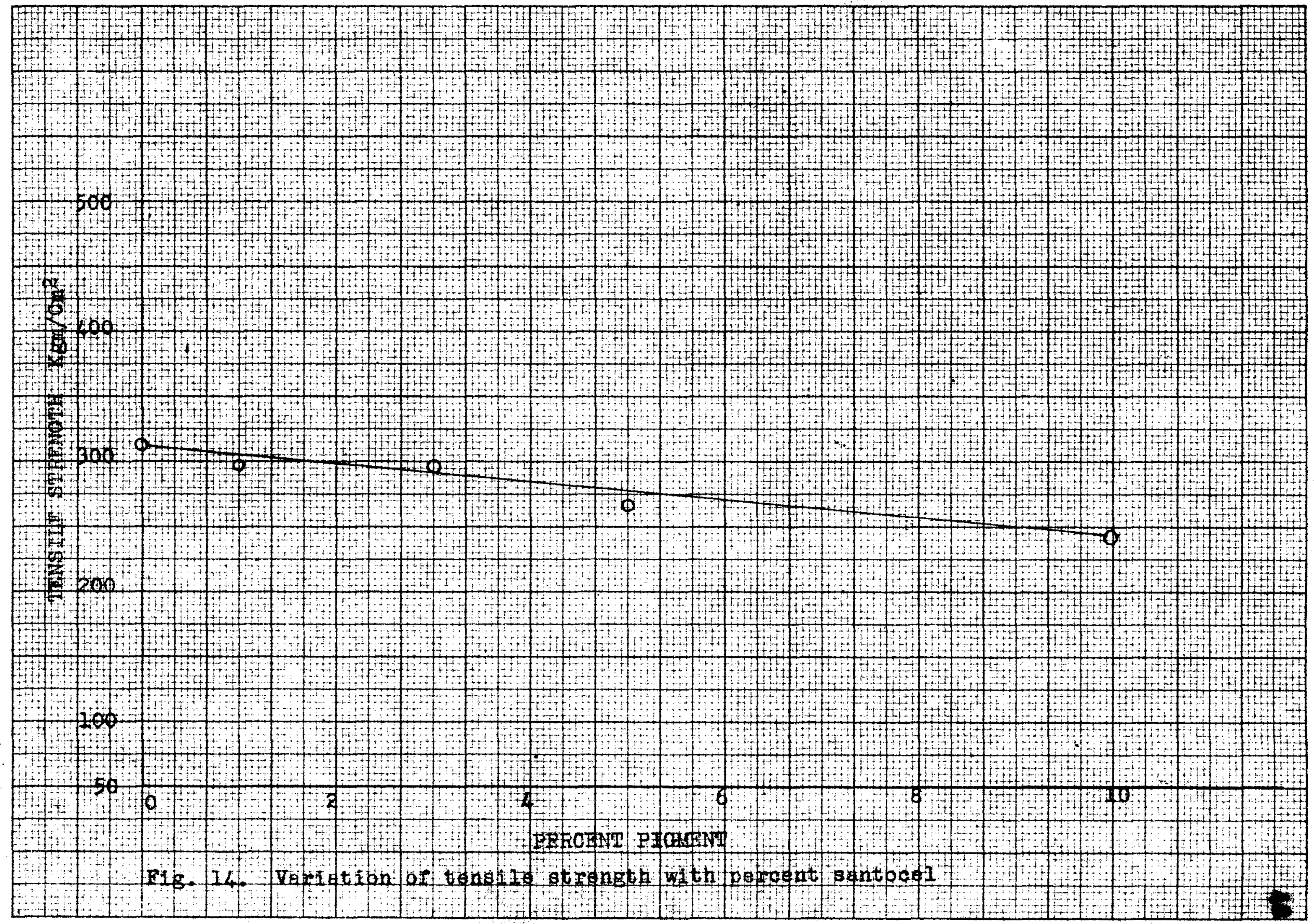




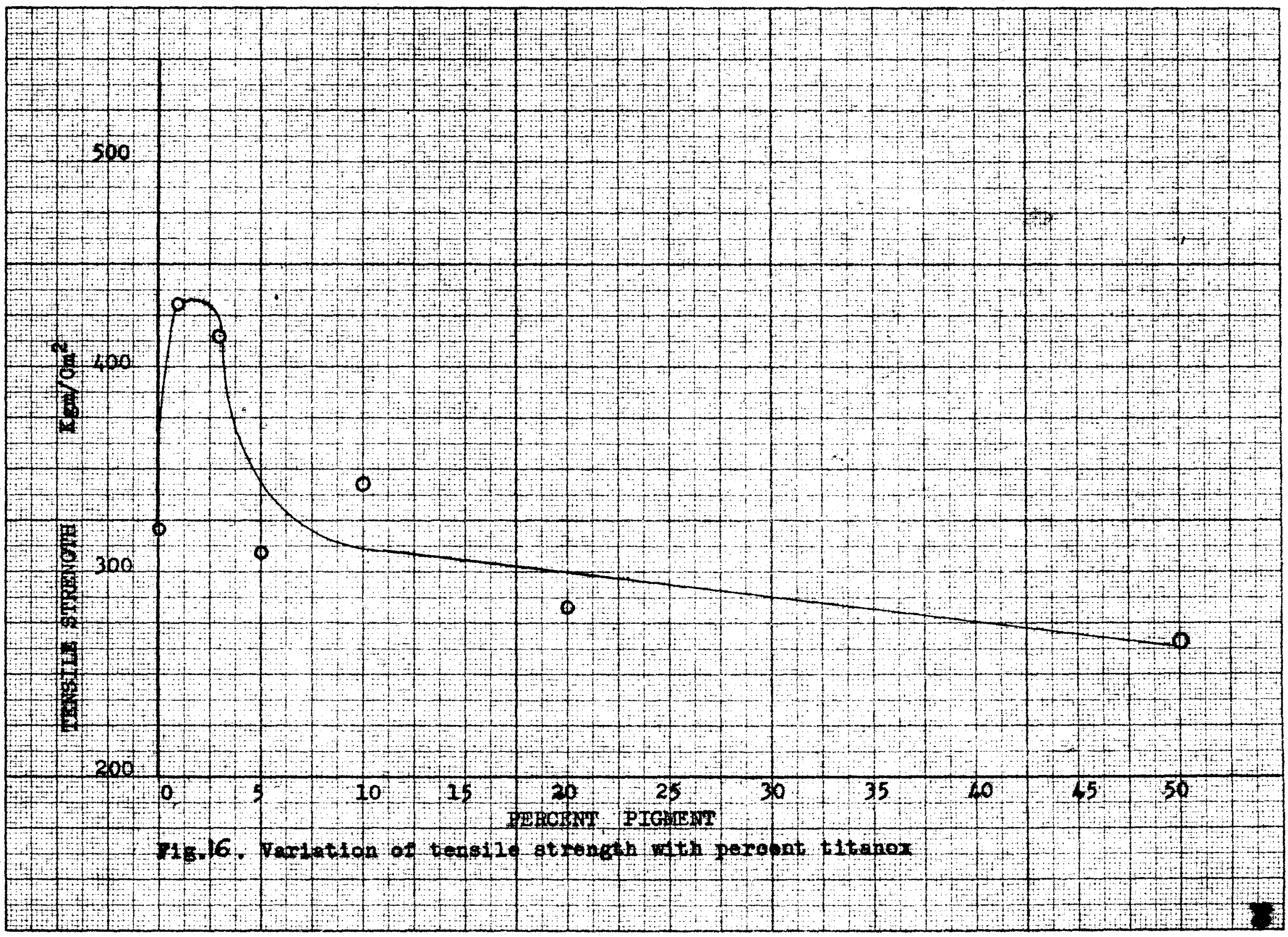




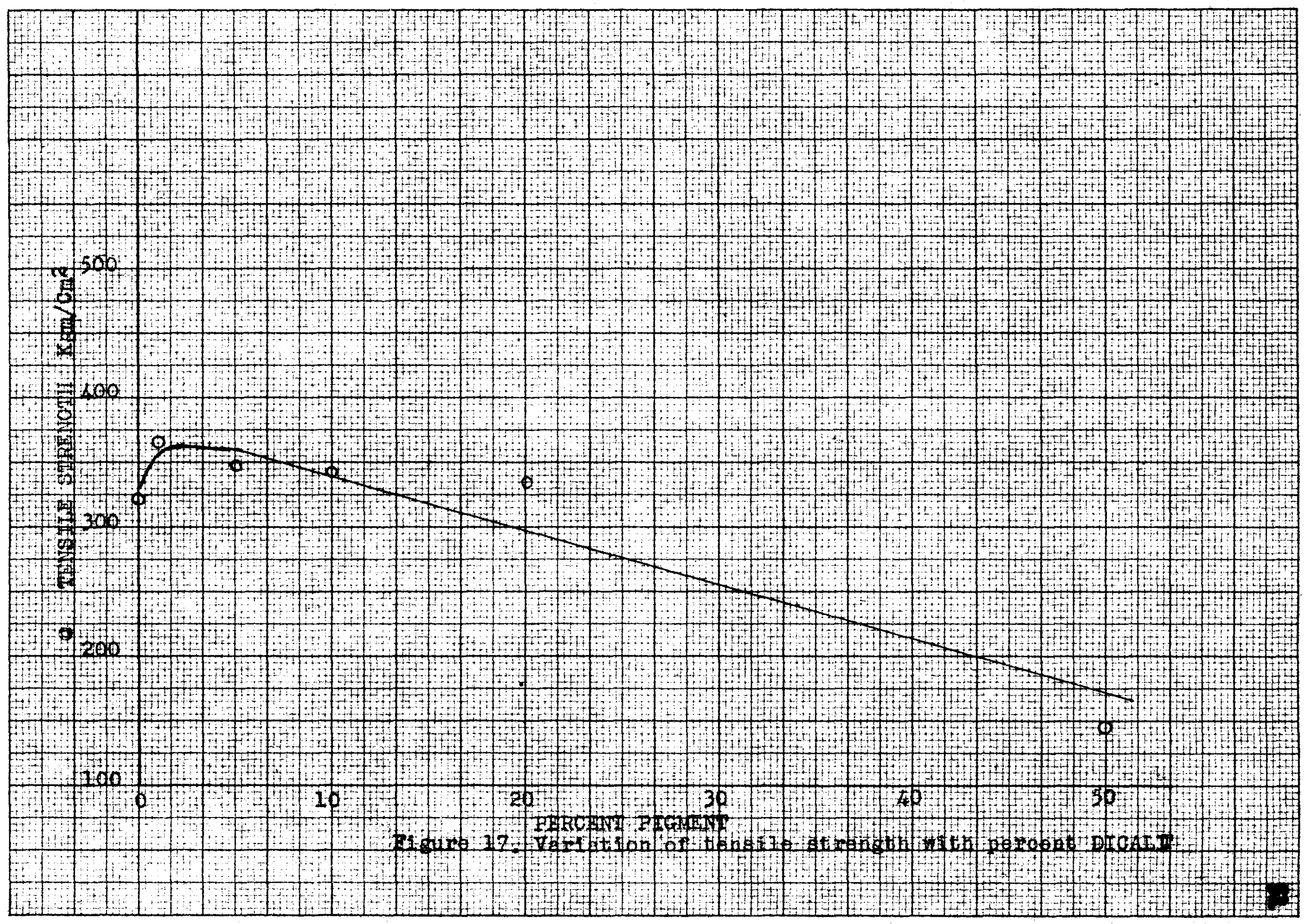




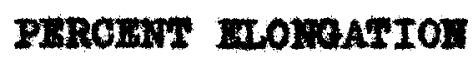

Peroont Elongation wa found to be maximm when $5.0 \%$ titanox was used to an inorease from $6.0 \%$ to $10.0 \%$. 8tylar but lese maxiced orfeots were noted in 21 thopone, oelite, baxyter, and ohina elay. see tables II - I. Arter examing the reaults caren in table I and the graphe arown in flgare 22 to 17, it oan be coon that titanox Imparted the maximan tena1le atrongth to ethoed rilns. Diealste and lithopene also now ravorable seanlte but the extent to wieh they arreot the tenc1le otrength is not very great, namely, in inorease of $33 \mathrm{rg} / \mathrm{mm}^{2} \mathrm{ter}$ 14thopono and 11 rov and $^{2}$ for baytes (Barlum sulfate).

$X$ wet bo kept in mind, however, that those values are oomeot within experimental orror of 5.0 percent. The Beott-rons1l. rester used had an exros or 5.0 peroant, and the readinge obtalned for pereont longation were not oxact. They are ecrreot within an exrer of 10.0 pereent. Henee these data do not provide a measure of the phraleal propertios undor examination but show gonoral trond.

27ro reasone for the Inereased tentile strongth of

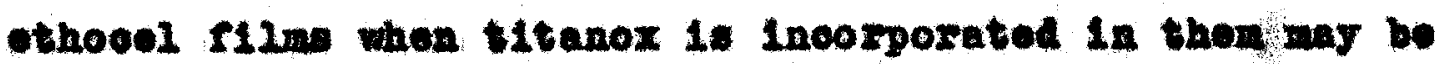
found in the collotel nature of the mixture.

Ethooel to polar in nature due to an unoren aistribution of the eleotrio oherges in 1ts molecule. It is quite poselble that, titunox for example, being in 
colloldal form offors a foundation, on and around whl on an adhosive proteotive onrelope, consiating of long chaln, ative (polar) molecules of othyl oellulose in formed due to adonrption phenomenon. These ethyl oollulose moleoule

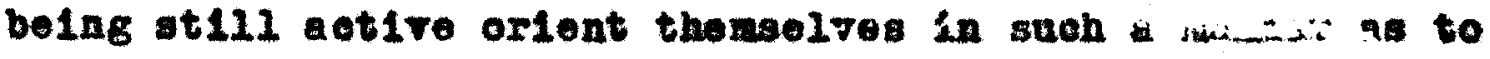
rorn a branohed Interlaced struoture with the other lons chains of similar ethyl cellulose molooules. Thus those resldual intermoleoular atraotive forces regain the atrength whioh was lost during the degradation of aeliulose molecule ohain.

It way be notioed that out of the silleoous p1gments, only dioall te imparted an increase in the tensile otrength of the flim. The rest of the silloa extenders have been produeed ohemloal $2 y$ and are in the form of simple partioles without any complloated struoture but dicallte is composed of diatomaoeous silloa partioles which have complloated otrueture. These partioles ma be thin and long or rloky and alscold or way be curred and boat shaped, with numerous pores and indentations. The diaton struoture of dicallte was probably the cause or an inoreased tenallo streneth.

Beoause of their shape and struoture the se diatoms have definite interleoing aotion in the laoquer mixture, providing latt10e through whlch the polar moleoules of thooel form ohains and moelles thus imparting a atrongth to the $\mathrm{MIn}$. 
54

:

ComCLUSTOR 
The results have definitely shown that pigmentation of the leoquer ald hate an effoct upon the fllm properties. The o2d conoeption that plementation lavariably produeed weakness in the I1Ims, did not have any justirication.

Mtanox was found to have a renarkable ability to produce an all round improvemont in the desired properties. It Inoreased the tensile strength, raised the sortening and molting points, peroentage elongation of the film at fallure was effeoted conslaerably. A laequer contalning 2.0\% titanox had the rollow properties:

$$
\begin{aligned}
& \text { Melting polnt....... } 120 \text { degrees } \mathrm{T} \text {. } \\
& \text { sortening point ...... } 86 \text { degrees } \mathrm{I} \text {. } \\
& \text { Tons110 atrength ..... } 425 \mathrm{re} / \mathrm{om}^{2}
\end{aligned}
$$

Pereentage Elongation at rallure. . 5.0\%

of the silleoous plgaents diealite seemed to be the most promialng. A laequer contelning $3.0 \%$ dioulite had the following properties:

volting polnt....... 202 degrees $\mathrm{I}$. sortening point...... 88.0 cegrees $\mathrm{r}$. Tens110 strength ...... $364 \mathrm{Ke} / \mathrm{om}^{2}$. Peroentage elongation at fallure . 4.40\% 
TABLI IT

WTHOCBL IAACUER WITHOUT PICDENT

\begin{tabular}{|c|c|c|c|c|c|}
\hline $\begin{array}{l}\text { P11 } \\
\text { Miokness } \\
\text { M11 }\end{array}$ & $\begin{array}{l}\text { Rensile } \\
\text { Strength } \\
\text { xom/on }\end{array}$ & $\begin{array}{l}\text { Percent } \\
\text { Elongation }\end{array}$ & $\begin{array}{l}\text { Milm } \\
\text { Thiokneas } \\
\text { Hile }\end{array}$ & $\begin{array}{l}\text { Sortening } \\
\text { Point }\end{array}$ & $\begin{array}{l}\text { Melting } \\
\text { point }\end{array}$ \\
\hline 2.60 & 329 & 5.9 & $1.7-2.6$ & 75.5 & 91.5 \\
\hline 1.90 & 326 & 6.0 & $1.7-2.6$ & 78.0 & 92.0 \\
\hline 1.70 & 324 & 3.6 & $1.7-2.6$ & 77.0 & 93.0 \\
\hline
\end{tabular}


TABIE III

prombar - - TItaxox

\begin{tabular}{|c|c|c|c|c|c|c|}
\hline $\begin{array}{l}\text { Peroent } \\
\text { P1 gent } \\
\text { On sollds }\end{array}$ & $\begin{array}{l}\text { Min } \\
\text { Thlokness } \\
\text { Mils }\end{array}$ & $\begin{array}{l}\text { Tonsile } \\
\text { Strength } \\
\text { Xen/on' }\end{array}$ & $\begin{array}{l}\text { Peroent } \\
\text { Blongation }\end{array}$ & $\begin{array}{l}\text { Filn } \\
\text { Thiokness } \\
\text { Wls }\end{array}$ & $\begin{array}{l}\text { Sortening } \\
\text { Point } y\end{array}$ & $\begin{array}{l}\text { Molting } \\
\text { Point }\end{array}$ \\
\hline \multirow[t]{3}{*}{1.0} & 1.9 & 425 & 4.62 & $1.6-2.2$ & 84.5 & 102.0 \\
\hline & 1.9 & 420 & 4.43 & $1.6-2.2$ & 85.5 & 100.4 \\
\hline & 1.5 & 432 & 5.00 & $1.6-2.2$ & 85.0 & 202.4 \\
\hline \multirow[t]{3}{*}{3.0} & 2.35 & 418 & 5.00 & $2.0-2.5$ & 87.0 & 104.0 \\
\hline & 2.20 & 417 & 3.75 & $2.0-2.5$ & 88.0 & 104.0 \\
\hline & 2.00 & 408 & 3.75 & $2.0-2.5$ & 87.0 & 205.0 \\
\hline \multirow[t]{3}{*}{5.0} & 2.84 & 308 & 9.00 & $2.5-2.6$ & 88.0 & 101.0 \\
\hline & 2.50 & 308 & 10.00 & $2.5-2.6$ & $-\infty$ & 101.0 \\
\hline & 2.50 & 307 & 8.75 & $2.5-2.6$ & $-\infty$ & 100.5 \\
\hline
\end{tabular}


TABLE III-(oont'd)

PIQUGNT - - MITAROX

\begin{tabular}{|c|c|c|c|c|c|c|}
\hline $\begin{array}{l}\text { Peroent } \\
\text { P1gment } \\
\text { on Solids }\end{array}$ & $\begin{array}{l}\text { P1m } \\
\text { Thiekness } \\
\text { M11s }\end{array}$ & $\begin{array}{l}\text { Tens110 } \\
\text { Strength } \\
\text { xgin/om2 }\end{array}$ & $\begin{array}{l}\text { Percent } \\
\text { Blongation }\end{array}$ & $\begin{array}{l}\text { Filn } \\
\text { Thiokness } \\
\text { Mils }\end{array}$ & $\begin{array}{l}\text { Sortening } \\
\text { Point } F\end{array}$ & $\begin{array}{l}\text { Molting } \\
\text { Point }\end{array}$ \\
\hline \multirow[t]{3}{*}{10.0} & 2.60 & 341 & 6.00 & $2.5-2.7$ & 89.0 & 100.0 \\
\hline & 2.50 & 340 & 6.30 & $2.5-2.7$ & 93.0 & 101.5 \\
\hline & 2.50 & 342 & 5.90 & $2.5-2.7$ & 92.0 & 102.0 \\
\hline \multirow[t]{3}{*}{20.0} & 2.60 & 284 & 3.00 & $2.3-2.7$ & 90.0 & 102.0 \\
\hline & 2.50 & 283 & 3.20 & $2.3-2.7$ & 92.0 & 101.5 \\
\hline & 2.40 & 284 & 3.50 & $2.3-2.7$ & 90.5 & 103.0 \\
\hline \multirow[t]{3}{*}{50.0} & 2.80 & 271 & 2.50 & $2.2-2.8$ & 89.5 & 103.5 \\
\hline & 2.50 & 293 & 2.50 & $2.2-2.8$ & 89.0 & 103.0 \\
\hline & 2.30 & 288 & 2.50 & $2: 2-2.8$ & 89.5 & $I 04.0$ \\
\hline
\end{tabular}


TABLE IV

LITHOPOIE

\begin{tabular}{|c|c|c|c|c|c|c|}
\hline $\begin{array}{l}\text { Peroent } \\
\text { Pigment } \\
\text { On Sollds }\end{array}$ & $\begin{array}{l}\text { Min } \\
\text { Thiokness } \\
\text { uils }\end{array}$ & $\begin{array}{l}\text { Tonsile } \\
\text { Strongth } \\
\text { rom/ome }\end{array}$ & $\begin{array}{l}\text { Peroent } \\
\text { Elongation }\end{array}$ & $\begin{array}{l}\text { Mlin } \\
\text { Thiokneas } \\
\text { M11e }\end{array}$ & $\begin{array}{l}\text { Sortening } \\
\text { Point }\end{array}$ & $\begin{array}{l}\text { Melting } \\
\text { Point } \mathrm{F}\end{array}$ \\
\hline \multirow[t]{3}{*}{1.0} & 3.1 & 290 & 5.875 & $+\cdots$ & 97.0 & 91.0 \\
\hline & 3.2 & 307 & 5.000 & $2.4-3.1$ & 87.0 & 92.0 \\
\hline & 2.4 & 281 & 3.750 & $2.4-3.1$ & 88.0 & 92.0 \\
\hline \multirow[t]{3}{*}{3.0} & 2.2 & 348 & 6.250 & $2.2-2.5$ & 76.0 & 94.0 \\
\hline & 2.2 & 357 & 6.250 & $2.2-2.5$ & 76.0 & 95.0 \\
\hline & 1.8 & 350 & 5.620 & $2.2-2.5$ & 81.0 & 94.0 \\
\hline \multirow[t]{3}{*}{5.0} & 2.3 & 348 & 3.375 & $2.2-2.6$ & 83.0 & 99.0 \\
\hline & 2.2 & 332 & 3.75 & $2.2-2.6$ & 82.5 & 98.5 \\
\hline & 2.2 & 340 & 3.75 & $2,2-2.6$ & 84.0 & 99.0 \\
\hline
\end{tabular}


TABLE IV (cont 'd)

\section{LITHOPOME}

\begin{tabular}{|c|c|c|c|c|c|c|}
\hline $\begin{array}{l}\text { Porcent } \\
\text { Pigment } \\
\text { On Solids }\end{array}$ & $\begin{array}{l}\text { Mln } \\
\text { Thioknese } \\
\text { Mils }\end{array}$ & $\begin{array}{l}\text { Tenalle } \\
\text { Strongth } \\
\text { remalom? }\end{array}$ & $\begin{array}{l}\text { Percent } \\
\text { ilongation }\end{array}$ & $\begin{array}{l}\text { P11n } \\
\text { Phiokness } \\
\text { Hile }\end{array}$ & $\begin{array}{l}\text { Softening } \\
\text { Polnt } \quad\end{array}$ & $\begin{array}{l}\text { Melting } \\
\text { Point }\end{array}$ \\
\hline \multirow[t]{3}{*}{10.0} & 2.5 & 326 & 5.5 & $2.7-2.5$ & 81.5 & 101.0 \\
\hline & 2.4 & 311 & 3.75 & $1.7-2.5$ & 82.0 & 99.0 \\
\hline & 2.2 & 322 & 4.75 & $1.7-2.5$ & 81.5 & 99.0 \\
\hline \multirow[t]{3}{*}{20.0} & 3.1 & 278 & 3.75 & $2.1-2.8$ & 91.0 & 99.0 \\
\hline & 2.8 & 265 & 3.75 & $2.1-2.8$ & 91.0 & 98.5 \\
\hline & 1.6 & 281 & 6.25 & $2.1-2.8$ & 91.0 & 98.5 \\
\hline \multirow[t]{3}{*}{50.0} & 3.0 & 225 & 2.50 & $2,2-3,0$ & \multirow{3}{*}{$\begin{array}{c}(\text { large varlat } \\
\text { Ion) }\end{array}$} & -105.0 \\
\hline & 2.3 & 232 & 3.13 & $2,2-3,0$ & & - \\
\hline & 2.2 & 236 & 3.23 & $2.2-3.2$ & & 102.5 \\
\hline
\end{tabular}




\section{TABLE \\ carros}

\begin{tabular}{|c|c|c|c|c|c|c|}
\hline $\begin{array}{l}\text { Pereont } \\
\text { Pigent } \\
\text { On Solide }\end{array}$ & $\begin{array}{l}\text { Min } \\
\text { Maikness } \\
\text { M11: }\end{array}$ & $\begin{array}{l}\text { Tonsile } \\
\text { Strongth } \\
\text { Kow/on? }\end{array}$ & $\begin{array}{l}\text { Peroent } \\
\text { Blongetion }\end{array}$ & $\begin{array}{l}\text { Finn } \\
\text { Thioknese } \\
\text { Iils }\end{array}$ & $\begin{array}{l}\text { Sortening } \\
\text { Polnt } F\end{array}$ & $\begin{array}{l}\text { Melting } \\
\text { Polint } 1\end{array}$ \\
\hline 1.0 & 1.8 & 323.0 & 3.90 & $1.8-2.5$ & 87.0 & 202.5 \\
\hline- & - & -- & - & & 87.0 & 102.0 \\
\hline- & - & - & - & - & 88.0 & 102.0 \\
\hline 2.0 & 2.4 & 281.0 & 6.25 & $1.6-2.0$ & 58.0 & 102.0 \\
\hline 3.0 & 2.2 & 280.0 & 5.00 & $-\therefore$ & - & 102.0 \\
\hline 4.0 & 2.5 & 281.0 & 6.25 & - & $-\infty$ & - \\
\hline \multirow[t]{2}{*}{5.0} & 2.2 & 280.0 & 5.50 & 1.9 & 90.0 & 104.0 \\
\hline & 2.1 & 275 & 5.20 & -- & $-\infty$ & $-\infty$ \\
\hline
\end{tabular}




\begin{tabular}{|c|c|c|c|c|c|c|}
\hline \multicolumn{7}{|c|}{ CrIITL: } \\
\hline $\begin{array}{l}\text { Percent } \\
\text { P1 gmont } \\
\text { On Solldas }\end{array}$ & $\begin{array}{l}\text { Min } \\
\text { Thioknese } \\
\text { Mile }\end{array}$ & $\begin{array}{l}\text { Tono110 } \\
\text { Strongth } \\
\text { Kovar }\end{array}$ & $\begin{array}{l}\text { Peroent } \\
\text { Blongetion }\end{array}$ & $\begin{array}{l}\text { Min } \\
\text { Thickess }\end{array}$ & $\begin{array}{l}\text { Sortendng } \\
\text { Polnt } F\end{array}$ & $\begin{array}{l}\text { Woltin } \\
\text { Polnt }\end{array}$ \\
\hline 10.0 & 2.5 & 266.0 & 4.4 & 2.4 & 91.5 & 107.0 \\
\hline 20.0 & 2.3 & 251.0 & 5.0 & $1.8-2.3$ & 92.0 & 123.0 \\
\hline & $\begin{array}{l}1.8 \\
2.3\end{array}$ & $\begin{array}{l}257 \\
258\end{array}$ & $\begin{array}{l}3.8 \\
5.0\end{array}$ & $\begin{array}{l}1.8-2.3 \\
1.8-2.3\end{array}$ & $\begin{array}{l}94.0 \\
93.0\end{array}$ & $\begin{array}{l}123.0 \\
123.0\end{array}$ \\
\hline 50.0 & 2.2 & 163 & 1.25 & $1.8-2.8$ & 108.0 & 132.0 \\
\hline & 2.6 & 162 & 1.83 & $1.8-2.8$ & 105.0 & 131.0 \\
\hline & 2.8 & 181 & 1.25 & $1.8-2.8$ & 107.0 & 232.0 \\
\hline
\end{tabular}


TABLE VI

DICALITE

\begin{tabular}{|c|c|c|c|c|c|c|}
\hline $\begin{array}{l}\text { PERCERT } \\
\text { PIGLERT } \\
\text { OI SOLIOS }\end{array}$ & $\begin{array}{l}\text { FTLM } \\
\text { FHIOXIRSS } \\
\text { ins }\end{array}$ & 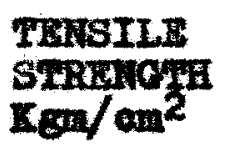 & $\begin{array}{l}\text { PERCEAT } \\
\text { ELOWOATION }\end{array}$ & $\begin{array}{l}\text { YILX } \\
\text { PHICKIESS } \\
\text { ums }\end{array}$ & $\begin{array}{l}\text { SorTrantma } \\
\text { POIMT } F\end{array}$ & $\begin{array}{l}\text { Matring } \\
\text { Porm } F\end{array}$ \\
\hline \multirow[t]{3}{*}{1.0} & 1.7 & 364 & 3.75 & $1.7-2.0$ & 84.0 & 97.5 \\
\hline & 1.8 & 361 & 3.75 & $1.7-2.0$ & 85.0 & 97.0 \\
\hline & 2.0 & 359 & 5.0 & $17-2.0$ & 84.0 & 97.0 \\
\hline \multirow[t]{3}{*}{3.0} & 1.9 & 365 & 4.4 & $2.4-2.8$ & 86.0 & 102.0 \\
\hline & 1.8 & 360 & 4.0 & $2.4-1.8$ & 87.0 & 102.0 \\
\hline & 2.8 & 361 & 4.2 & $2.4-1.8$ & 87.0 & 202.0 \\
\hline \multirow[t]{3}{*}{5.0} & 2.4 & 362 & 6.88 & $2.4-2.5$ & 88.0 & 102.0 \\
\hline & 2.4 & 368 & 5.00 & $2.4-2.5$ & 90.0 & 102.5 \\
\hline & 2.5 & 337 & 5.00 & $2.4-2.5$ & 88.0 & 102.5 \\
\hline
\end{tabular}




\begin{tabular}{|c|c|c|c|c|c|c|}
\hline & & & WI loont'd & & & \\
\hline & & & DTCALITE & & & \\
\hline $\begin{array}{l}\text { Peroent } \\
\text { P1 gment } \\
\text { On Solldis }\end{array}$ & $\begin{array}{l}\text { Filn } \\
\text { Thiokness } \\
\text { Mila }\end{array}$ & $\begin{array}{l}\text { Tons110 } \\
\text { Strength } \\
\text { revalon }\end{array}$ & $\begin{array}{l}\text { Percent } \\
\text { Elongation }\end{array}$ & $\begin{array}{l}\text { F11m } \\
\text { Th1 aknoss } \\
\text { ulis }\end{array}$ & $\begin{array}{l}\text { Sortenias } \\
\text { Polnt F }\end{array}$ & $\begin{array}{l}\text { Molting } \\
\text { Point }\end{array}$ \\
\hline 10.0 & 2.6 & 34 & 5.0 & $2.2-2.5$ & 87.0 & $102=0$ \\
\hline & 2.5 & 340 & 5.3 & $2.2-2.5$ & 89.0 & $103 \times 0$ \\
\hline & 2.5 & $339=$ & 4.8 & $2.2-2.5$ & 89.5 & 203.0 \\
\hline 20.0 & 1.8 & 329 & 3.75 & $1.5-1.8$ & 92.0 & 104.0 \\
\hline & 1.5 & 353 & 3.75 & $1.5-1.6$ & 93.0 & 104.0 \\
\hline & 1.7 & 335 & 4.00 & $1.5-1.8$ & 91.5 & 102.0 \\
\hline 50.0 & 2.5 & 180 & 0.125 & 2.5 & (raxled muoh) & 121.0 \\
\hline & 2.7 & 109 & 0.125 & $2.5-3.0$ & (varied muoh) & 121.0 \\
\hline & 3.0 & 114 & 0.125 & $-\infty-\infty$ & (raried moh) & 124.0 \\
\hline
\end{tabular}


TABLE VII

BARYTES

\begin{tabular}{|c|c|c|c|c|c|c|}
\hline $\begin{array}{l}\text { Pereent } \\
\text { P1 gaent } \\
\text { On Sollda }\end{array}$ & $\begin{array}{l}\text { Min } \\
\text { Thiekness } \\
\text { His }\end{array}$ & $\begin{array}{l}\text { Tenalle } \\
\text { Strongth } \\
\text { Kem/on }\end{array}$ & $\begin{array}{l}\text { Pereent } \\
\text { Biongation }\end{array}$ & $\begin{array}{l}\text { Filn } \\
\text { Thiokness } \\
\text { Hils }\end{array}$ & $\begin{array}{l}\text { Sortening } \\
\text { Polnt F }\end{array}$ & $\begin{array}{l}\text { Xeiting } \\
\text { Point } F\end{array}$ \\
\hline \multirow[t]{3}{*}{1.0} & $2: 3$ & 297 & 6.25 & $2.3-2.8$ & 76.0 & 93.5 \\
\hline & 2.8 & 300 & 8.19 & $2.3-2.8$ & 77.0 & 92.5 \\
\hline & 2.5 & 275 & 5.75 & $2.3-2.8$ & 77.0 & 93.0 \\
\hline \multirow[t]{3}{*}{3.0} & 2.2 & 321 & 7.50 & $2.2-1.8$ & 76.0 & 93.3 \\
\hline & 1.8 & 328 & 6.25 & $2.2-1.8$ & 78.0 & 93.5 \\
\hline & 2.0 & 318 & 6.00 & $2.2-1.8$ & 78.0 & 94.0 \\
\hline \multirow[t]{3}{*}{5.0} & 2.4 & 305 & 7.5 & $2.0-2.5$ & 81.0 & 96.6 \\
\hline & 2.1 & 309 & 6.0 & $2.0-2.5$ & 81.5 & 96.0 \\
\hline & 1.75 & 297 & 5.0 & $2.0-2.5$ & 81.0 & 95.5 \\
\hline \multirow[t]{3}{*}{10.0} & 2.3 & 295 & 5.25 & $2.0-2.3$ & 83.5 & 101.5 \\
\hline & 2.3 & 295 & 3.75 & $2.0-2.3$ & 82.5 & 101.5 \\
\hline & 2.0 & 295 & 3.75 & $2.0-2.3$ & 83.0 & 100.5 \\
\hline
\end{tabular}




\section{TABLS VII}

SAFrOCEL

\begin{tabular}{|c|c|c|c|c|c|c|}
\hline $\begin{array}{l}\text { Peroont } \\
\text { P1 gent } \\
\text { on sollds }\end{array}$ & $\begin{array}{l}\text { Filn } \\
\text { Thtokness } \\
\text { Mils }\end{array}$ & $\begin{array}{l}\text { Tenalle } \\
\text { Strongth } \\
\text { Kais /om2 }\end{array}$ & $\begin{array}{l}\text { Pereont } \\
\text { Elongation }\end{array}$ & $\begin{array}{l}\text { Min } \\
\text { Thiokneses } \\
\text { Mile }\end{array}$ & $\begin{array}{l}\text { Sortentang } \\
\text { Point } F\end{array}$ & $\begin{array}{l}\text { Helting } \\
\text { Point }\end{array}$ \\
\hline \multirow[t]{3}{*}{1.0} & 2.30 & 299 & 4.38 & $2.3-2.5$ & 77.0 & 97.0 \\
\hline & 2.10 & 295 & 4.35 & $2.3-2.5$ & 78.0 & 98.0 \\
\hline & 2.30 & 294 & 4.38 & $2.3-2.5$ & 78.0 & 98.0 \\
\hline \multirow[t]{3}{*}{3.0} & 3.0 & 299 & 5.000 & $2.4-3.5$ & 76.5 & 98.0 \\
\hline & 2.5 & 298 & 5.20 & $2.4-3.0$ & 79.0 & 102.0 \\
\hline & 2.4 & 297 & 5.12 & $2.4-3.0$ & 79.5 & 102.0 \\
\hline \multirow[t]{3}{*}{5.0} & 2.60 & 271 & 3.12 & $2.1-2.6$ & 82.57 & 96.5 \\
\hline & 1.7 & 273 & 3.12 & $2.1-2.6$ & 82.0 & 96.5 \\
\hline & 2.1 & 267 & 3.12 & $2.2-2.6$ & 82.5 & 97.6 \\
\hline \multirow[t]{3}{*}{10.0} & 2.5 & 250 & 3.125 & $2.5-2.6$ & -- & 96.0 \\
\hline & 3.0 & 244 & 3.00 & 2.5 & 82.5 & 98.0 \\
\hline & 2.6 & 246 & 3.22 & 2.5 & 83.0 & 98.0 \\
\hline
\end{tabular}

Conglomeration of p1gment took place about $10.0 \%$ piemont. 


\section{TABLE IX}

BEMTONITE

\begin{tabular}{|c|c|c|c|c|c|c|}
\hline $\begin{array}{l}\text { Peroent } \\
\text { P1 gant } \\
\text { On Sollds }\end{array}$ & $\begin{array}{l}\text { M1m } \\
\text { Thiokne } 8 s \\
\text { Mls }\end{array}$ & $\begin{array}{l}\text { Tens1le } \\
\text { Strength } \\
\text { Kem/on2 }\end{array}$ & $\begin{array}{l}\text { Percent } \\
\text { Elongation }\end{array}$ & $\begin{array}{l}\text { Tilm } \\
\text { Thiokness } \\
\text { Mils }\end{array}$ & $\begin{array}{l}\text { Sortening } \\
\text { Point I }\end{array}$ & $\begin{array}{l}\text { Molting } \\
\text { Point }\end{array}$ \\
\hline 1.0 & 2.3 & 309 & 5.5 & 2.4 & 80.0 & 95.0 \\
\hline 2.0 & 2.2 & 295 & -- & $-\infty$ & -- & -- \\
\hline \multirow[t]{3}{*}{3.0} & 2.7 & 287 & 4.080 & $2.1-2.7$ & 82.0 & 95.5 \\
\hline & 2.1 & 307 & 6.250 & $2.1-2.7$ & 82.0 & 96.0 \\
\hline & 2.2 & 275 & 4.125 & $2.1-2.7$ & 81.4 & 97.0 \\
\hline 4.0 & 2.2 & 274 & $\cdots$ & $-\infty-\infty$ & $-\infty$ & $\cdots$ \\
\hline 5.0 & 2.55 & 274 & $\cdots$ & 2.5 & 85.0 & 98.0 \\
\hline-- & - & $\cdots$ & $-\infty$ & $\cdots$ & $\cdots$ & 99.0 \\
\hline-- & $-\infty$ & - & $-\cdots$ & -- & $-\infty$ & 99.0 \\
\hline
\end{tabular}


TABIE IX (eont'a)

BENTONIT

\begin{tabular}{|c|c|c|c|c|c|c|}
\hline $\begin{array}{l}\text { Percent } \\
\text { Plegent } \\
\text { On sollds }\end{array}$ & $\begin{array}{l}\text { Film } \\
\text { Thioknesa } \\
\text { Mtis }\end{array}$ & $\begin{array}{l}\text { Tenoile } \\
\text { Strength } \\
\text { Kara/ont }\end{array}$ & $\begin{array}{l}\text { Percent } \\
\text { Elongation }\end{array}$ & $\begin{array}{l}\text { Pilm } \\
\text { Thiokness } \\
\text { Mils }\end{array}$ & $\begin{array}{l}\text { Sortening } \\
\text { Point } F\end{array}$ & $\begin{array}{l}\text { Melting } \\
\text { Point }\end{array}$ \\
\hline 10.0 & 2.8 & 297 & 2.50 & $1.8-3.2$ & 87 & 98.0 \\
\hline \multirow[t]{2}{*}{. } & 2.1 & 294 & 2.32 & $1.8-3.2$ & & 98.0 \\
\hline & $-\infty$ & - & --- & $-\infty-\infty-\infty$ & $-\infty$ & 98.5 \\
\hline \multirow[t]{3}{*}{20.0} & 2.0 & 257 & 1.39 & $2.0-3.0$ & 88.5 & 212.5 \\
\hline & 3.0 & 259 & 2.00 & $2.0-3.0$ & 88.8 & 211.0 \\
\hline & 1.8 & 250 & 1.80 & $2.0-3.0$ & 89.0 & 111.0 \\
\hline \multirow[t]{3}{*}{50.0} & 1.8 & 239 & 2.50 & $1.8-2.2$ & 93.0 & 112.0 \\
\hline & 2.8 & 243 & 1.25 & $1.8-2.2$ & 98.0 & 115.0 \\
\hline & 1.7 & 212 & 2.30 & $1.8-2.2$ & 98.0 & 115.0 \\
\hline
\end{tabular}




\section{TABLE $X$}

\section{CHITA CLAY}

\section{Percent}

Pigment

F11m

Thiokness

$3.0 \quad 1.9$

2.0

2.1

3.0

1.9

4.0

1.8

5.0

1.9
Tenolle Strength Kena/ om2

302

313

309

305

300
Percent

Elongation

6.25

8.75

7.5

5.0

6.2 
PARE II

A STUDY OI THE EFTEOT of SUI LIGHT ON THR COLOR OF PIOUENRS

InRRODUCTrox 
It hes been known for some time that there is a change in the color of oouting as tine progresses but no quantitative work has been reported to deteralne the extient and the direotion in wioh the color ohange takes place. This ohange is very low and is hardy notloeable by the oye, if oxamined at short intervala. However, after a longer period, normally a faline of color becomes notloeable and the coating produces allghtly ohanged appearanoe. Howerer, fading doea not necessarily take plece to produce oolor which is undesirable, on the contrary it has been observed that oertain tints, tones, and shades, resulting from fading are quite desirable. W1th this in view, it was considered that if the change in color vith tine of certain plgaents in a vehiole could be known prior to its applloation, steps could be taken -1ther to oheok that rading by the incorporation of inhlbiting materlal: or to formulate paint suoh that on exposure it would degrade to color which would not seem unpleasant or that, the raded oolor might be oren nore appealing to the eye. Th1s Invertigation was designed to atudy the dry exposure charaoteriatios of the afferent plements in series of five tints per pigment when they were incorporated as palat. The work was begun at the euggestion of the Louisville Palnt and Varnish club as worthwile contribution to the knowledge in the fleld. 
HISTORICAL 
Albert H, Munsell was the f1rst person in the United States of Amerioe who organized and put into definite aystem, rague 1deas and disconneoted staterents regarding the measurement of color $(24)$. He reasoned that the color appearance of objeots was apparent only in objeots and so proposed to set up - Berles of colored papers whioh varied equally in all direotions In the oolor domain in terms of visual appearanoe. He did not consider the physioal variables involved, but restrioted himself to the oolor as suoh, vlewed under standardized conditions. A color atlas was produced by him, contalning examples of oolors whloh varled in roughly unifora steps over a large range of surface colors.

Lunsell defined the three variables of color as hue, value, and ohroma. Hue was that quallty by whioh one color family is distingulahed from another, as red from green, or green from blue. It is due to the differenoe in wavelengths of llght falling on our eyes, produoing alfferent oolor sensations. Value is the 11ghtness of a color. It is that quality by whloh we distinguigh a 11ght oolor from a dark one. Color ralues are loosely oalled tints and shades, but these terme axe frequently misapplied. A tint should be a light ralue, and shade dark ralue.

Chroma is the etrength of a color! A oolor might be woak, or it might be intensely strong, for oxample Briok Red and Vemillion red, the former is weak, whlle the latter is strong. 
These three aspeots or oolor were arranged into a three dimensional oolor solid having a rertioal black to wh1te axis. Around this wore arranged the lines in equal angular spaolng and ohroma was defined as tho diatanoe Irom the axis at any partioular color value.

It was Intended that the sample to be speolfled ohould be held near the atlas and the position of the sample with respeot to the aotual chips determined. The spoolfioatIon of the color thus consisted of a numerioal statement of 1ts position on the soales of the solla.

It must be noted, howerer, that these mall matte surfaced ohlps represent only one type of surface, thelr energy alstributions are unlque, and therefore they are not sultable for comparison with all types of possible distributions. In 1943, a comalttee of the Opt10al Soclety of Amer10a atudiod the Munsell aystem and reoomended a reopacing of the colors beced on purely parcholeg10al approaeh (16).

The basis of this aystem is the serien of international agroements commonly referred to as the I.C.I. aysten (or the CIE aystem in England and on the Continent). This international Corendasion on Illumination (Complasion Internationale d'Bolairage) adopted as atondard for international use luminosity ourre, oolor-mixture ourres for these Imaginary standard 11ghts, specifio onergy distribution for a bas10 light souroe, several supplementery light sources and number of apertures. 
The three ralues which derine a oertaln color, in the O.3,A. graten are oalled Hue, Brightness and Saturation, roughly corresponding with the Hue, Value and Chroma, respectively, of the Munsell Systen.

The caloulation of the exaltation values for a sample lead to three numertoal renults. Two of these are the triohromat10 ooefriolonts $X$ and $I$, representing the fraotional amounts of the red and the green primaries necessary to produoe hue and saturation moh with the semple and a third $z$, representing the luminanee of the sample. The I.C.I. Alagram Is plotted in terms of $X$ and $I$ and the value of $\mathrm{Z}$ 10 written beside the point.

Bqual distances in the I.O.I, Alagram do not mean equal visual differenoes. In faot it has been demonetrated that it is not posalble to oonstruet abromatielty dagram in whioh perooptible differonees are repreaented by the same diatances at each point.(29) To overoome this affeloulty Judd $L$. Sooffleld and Funter put forward anothor system whioh 18 aetually an improvement on the I.C.I. system.

These three workers defined a coordinate system In two dimenstons, $\alpha$ and $\beta$, In whioh, for oolors of the was monochromat1c rerleotances, equal al atances on the groph are oqual approximately to equal peroeptual color difforenoe. These coordinates sre derined in terms of the I.C.I. Coordinates ast 


$$
\begin{aligned}
& \alpha=\frac{2.4266 x-1.3631 y-0.3214}{1.0000 x+2.2633 y+1.1054} \\
& \beta=\frac{0.5710 x+1.2447 y-0.5408}{1.0000 x+2.2633 y+1.1054} .
\end{aligned}
$$

or In terms of the Blue, Amber, and Green readings of the Euster mult1-purpose refleotoneter as: (18)

$$
\alpha=\frac{A-G}{A+B+2 G} \quad, \quad, \beta=\frac{8 \cdot 4(G-B)}{A+B+2 G} .
$$

$X$ and $I$ bave already been expla1ned. $A, B$, and $G$ represent the soale ralue on the I. Rerlectometer as compared to a atandard ralue. 
APPARATUS 
HUNTER MULTIPURPOSE REFLECTOMETER

1) Plan of the Instrument:

Figure 19 is diagram of the Hunter Rerlectometer with a partial elevation through $Q-Q$ to show the path of the gloss beam. This penoil of light is separated from the entrant beam by the small aluminum mirror 7 , and I1nelly reaches atationary photoeell, $N$, termed the oloss Photocell, by way of the Gloss surface H, which is in position to recelve the bean at 45 degrees, and rerleot it at -45 degrees along the path toward the gloss photooell. The lines indioating both the centers and the odges of the light pathe from the source to the respeotive photocells are heary. The positions of all elements neoessary for the operation of the instrument are shown. The elevated part of the gloss bear between the mirrors, $F$ and $I$, is omitted in the plan but is shown in the partial elevation. The instrument is designed to operate eocording to null method. Light from the single souroe is divided into two paths, each of wich ultimately reaches a barrier-layer photocell. The two cells are connected with polerities opposing to the terminals of the galvanometer, giving the ourrent balancing ofroult. The light direrges from the filament of the projeotion lamp, 0 , and passes through a round ud ndow in the aluminum insulating shleld B. Beyond this shleld, the beam may pass through one of several speotrally selective iliters on a disk $\mathrm{B}$, and reach the collimating lens mounted in the wall of the 
Instrument housing.

The approximately parallel bean leaving this

lens then proceeds in large part, to the vertioaliy pleced refleoting surfaoe, $a$, on which it is inoldent at 45 degrees. The refleotion photooell, A, to whioh the scales are atteohod views the roflection surface from a variable aistánce. The plane wirror, $F$, latercepts a small part of the eylindrical beam and reflects it upward to inoidenee at 45 degrees on the horlzontally placed gloss surfeoe, H. The light reflected by th1s surface at the angle of mirror reNleotion, -45 degrees, strikes mirror $I$, which is in the sane plano as mirror 7 . The center of this gloss beam is thereby returned to the horlzontal plane and pasaes through a lens and gloss aperture where an lmage of the souroe is formed. Behind this aperture is the semidefusing refleotor, M, adustable in its angular position to control the fraction of light directed from it to the gloss cell, N. Several different apertures in a diak may be interchanged to vary the spread of the light in the gloss beam passed toward the gloss oell for measurement.

Two sceles are ruled on the arm attached to tha morable rerlection cell, one for reflection, $R$, the other for gloss, S. Stray light whioh might register on the photocells is reduced to a minimum by painting interior surfeces of the Instrument dull black, by mounting the morable reflection cell in a tunnel, and by dividing the instrument 
Interior into compartments sepsated by the sheet metal partitions indioated by light dotted ilnes in Ilgure 7.

\section{ACCELERATED WEATHERINO MACHIME}

The acoelerated weathering unit onnsistis of a sheot oopper oylinder about three feot in diameter and about threo and half foet in height. An eloctrlo arc arrangement is provided in the oenter of thls oylinder. The oarbon eleotrodes are remored at a definite speed towards each other by moans of an leotrio clookwork, the motion of the eleotrodes is proportionel to the rate at whioh the aro consumes the carbon. The oarbon aro arrantenent 1a enclosed in a franowork of metal with speolel heat-resistent glass windows to allow a mintmun transmission of radiation.

Along the inside of the outer oylindricel vessel

aro large number of hooks from whioh test panels can be suopended. This oflinder revolves round 1 ts vertical axis at the rate of one-half revolution per hour. There is also a spray nozzle which may be made to spray vater over the surface of the penels and thus give the effeot of rain. The central aro light chamber is connected through duct to an exhaust fan, which remores the fumes and gases evolved. The aro chamber oan be lifted out of the maln ohamber for the purpose of cleaning and the replacement of the carbon - leotrodes. An eleotrio meter keeps a reoord of the tim the 1nstrument is in operation. The top and bottom of the unit are covered by means of copper shenting to prevent a strong exposure to the eye. 


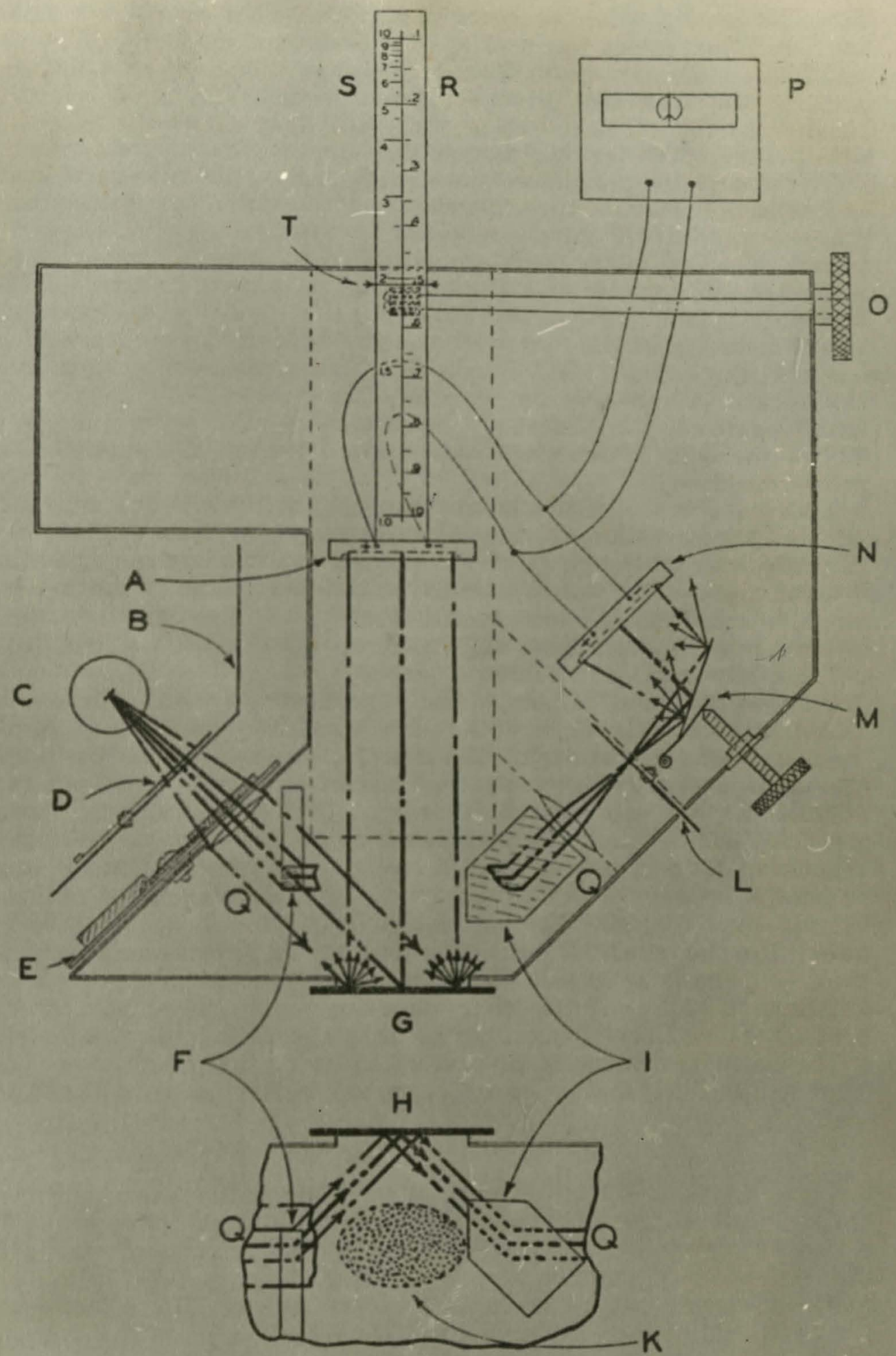

Figdre 7.-Diagram of multipurpose reflectometer.

$A$, reflection photocell; $B$, aluminum shield; $C$, lamp; $D$, shutter; $E$, fliter disk; $F$, small mirror which divides beam; $Q$, reflection surface; $H$, gloss surface; 1 , aluminum mirror; $K$, cross section of area through which light passes between reflection surface and reflection photocell; $L$, disk containing gloss apertures; $M$, screw and semidiffusing reflector; $N$, gloss photocell; 0 , knob to move cells and scales; $P$, galvanometer: $\boldsymbol{R}$, reflection scale; $\mathcal{S}$, eloss scale; and T, index. Elevation through $Q-Q$ at the bottom shows how light is directed up to the gloss surface, $H$, from the plane of the other beams of the instrument below. 


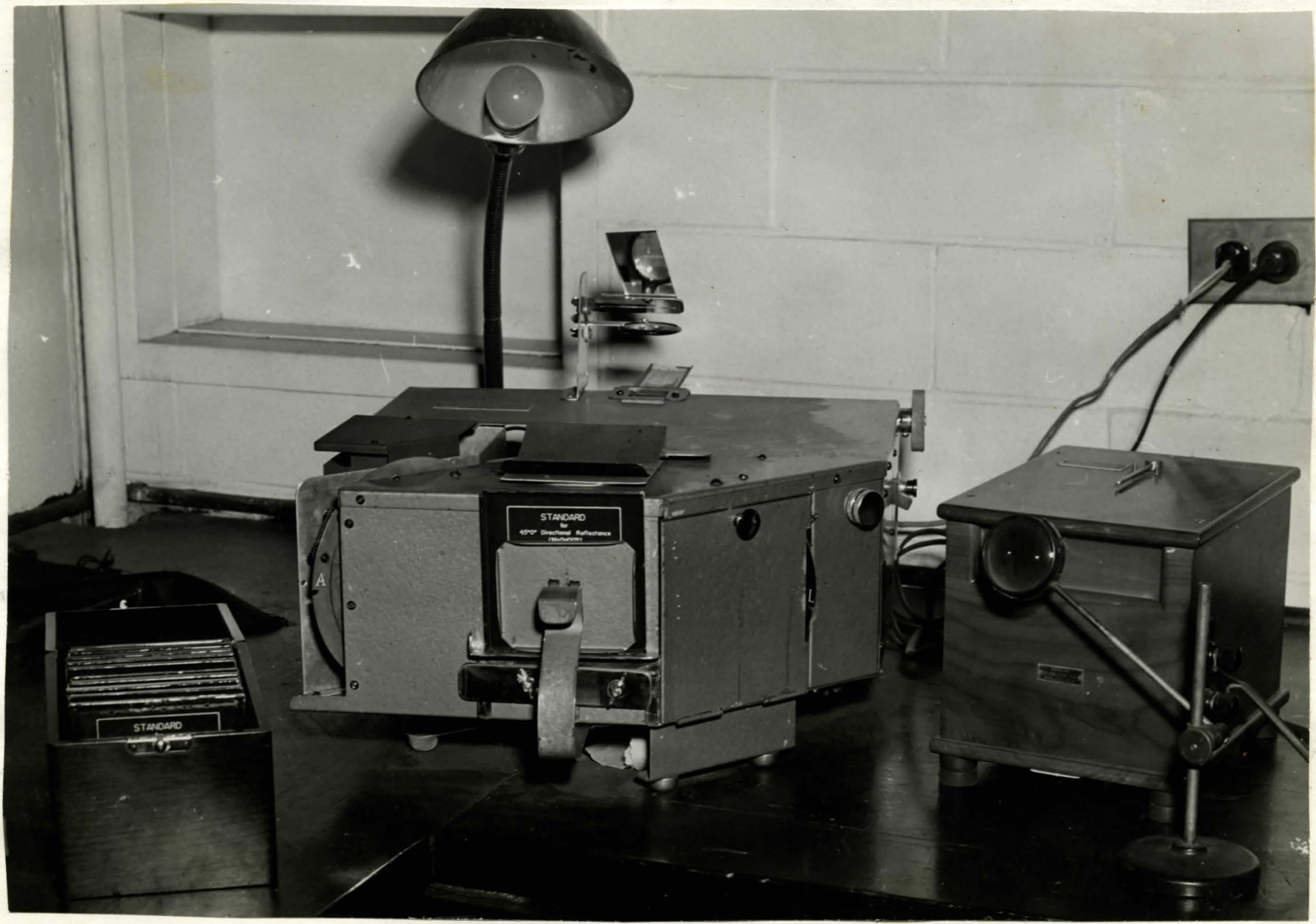

HI. 20 HUNTHR NULTIPURPOSE REFLETOMRTER 
EXPERIMINTAI 
In general the experimental part of this work oonelsted of mesuring the ohange in 45 degrees, 0 degrees,. apparent refleotance, relative to a standard, through filters for tristimulus colorimetry $\cdot$. The change in the apparent refleotance was brought kibout by exposure to ultra violet 11ght. To begin with there were three ldenticul sets of thirty panels each, out of which, two sets having the same 45 degree, 0 degree apparent relleotance had to be ohosen. Bach set was further divided fnto six sets having the followpaint compositions spray coated on them.

All panels were sprajed on both at des with 52-P18 zino chromate primer and alx dried at least 72 hours. Two coats or colors were then sprayed on eech panel, allowing at least 72 hours air arying between coats.

COMPOSITION OF COLOR PAINTS

The rehlole for all the colors was the same, namely, Glyptol number 2504 reduced with mineral spirits to $50 \mathrm{per}$ cent N.V. and napthenate drlers and National Aniline Ant1sin Agent added as follows: $0.075 \%$ cobalt, $0.5 \%$ lead and 0.46 ant1 sin agent, based on the non-rolatile. Vis0osity of the above wes from $I-0$. Constants on glyptol number 2504 . 
CONSTANIS OF SOLUTION:

Sollds Content -.. We1ght.......59-618

Solvent --.----Potroleum Spirits

V1000sity $(\mathrm{O}, \mathrm{H}),. \ldots, \ldots, \ldots, \mathrm{U}$

Color- - -(Gardner). . . . . 8 Man

Aold No, of Solution . . . . 4-6

Pounds per gallon . . ... 7.7

RBEIN SOLIDS CONSTANTS:

Phthal10 Anhydridé ..... 24\%

Rosin or derivative ...... Nono

Phenollo Resins . . . . .. None

011 Aoids Content . . . . . 60\%

Type of $011 . . . . . .$. . . . soya

RICMENTS:

Yellows:

Y-1-3\#-\#2518 kx. Lt, Yellow Per Gal. Veh10le

$1-I-1$ - $1 \frac{1}{2} \#$ \#2518 $\mathrm{gx}$. Lt. Yellow Por Gal. Vehiole

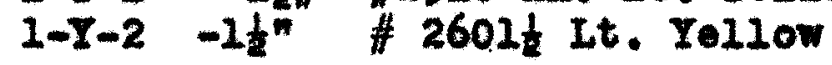

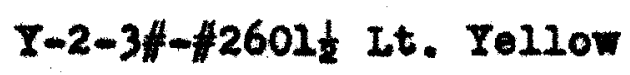

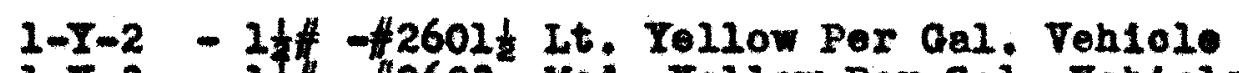

1-Y-3 - It $\$ 2603$ Mod. Yollow Per Gai. Vehicle

I-3-3\#-\#2303 - Led. Yellow Per Gal. Veh1010 
Orenges:

0-1 -\#3 - 2604 Lt. Yollow Per Gal. Vehiole

1-0-1 -1 th - 2604 It. Orange Per Gal. Vehicle

$1-0-2-1$ fl $-42213 \mathrm{Med}$. Orange

0-2-3\# \#2213 Led. Orange Per Gal. Vehicle

0-3-3\# \#2209 Dr. Orange Per Gal. Vehlole

$0-4-3 \hbar-t 2206 \mathrm{Ex}$. Dark Orange

Rede:

R-1-12 oz \# 1077 Ix. It. Toluidine, Per Gal. Vehiole

R-3-12 oz \# 1073 Dr. Toluidine Per Gel. Veh10le

2-R-3 - 18 oz \# $1073 \mathrm{dk}$. Toluldine Per Gel. Vehtole

1-R-5 - 4 oz \# 1070 D.D.D. Toluldine Per Gal.Vohidelo

1-R-3 -40z \# 1073 Dk. Toluidine Per Gal. Vehicle

2-R-5 -80z \# 1078 D.D.D. Toluidine Per Gal.Veh1ole

R-5-12 oz \#1078 D.D.D. Tolulaine Per Gal. Veh1cle

Creens:

0-1-16 oz. \#8405 Lt, Green Per Gal. Veh1ole

0-2-16 oz, \#8410 Med, Green Per Gal. Veh1010

2-0-2 -10.67 oz \#8410 Med. Green Per Gal.Vehiole

1-a-3 - 5.33 oz \#8425 Dk. Groen Per Gal. Vehlole

0-3-16 oz- \#8425 Dk. Green Per Gal. Veh10le 
Phthaloojanine Blues:

PB-2-40z. \#4845 Zulu Biue Per Gal, Veh10le 8 oz. T1-Pure R-610*

3-PB-1 -4 oz. \#4845 Zulu Blue Per Gal. Vehiole 1-PB-2- 6.5 oz. T1-Pure R-610*

1-PB-1 - 4 02. \#4845 Zulu Blue

I-PB-2 - 5 oz. T1-Pure R-610

$1-\mathrm{PB}-1$ - 4 Oz. \#4845 Zulu Blue

3-PB-2 - 3.5 oz. T1-Pure R-610 Per Gal. Veh1ole

PB-2 - 4 oz. \#4845 Zulu Blue

2 oz. T1-Pure R-610 Per Gal. Vehiele

M110r1 Blues:

MB-1 - 4 oz. \#4022 M11or1 Blue Per Gal. Veh101e 8 oz. T1-Pure R-610

3-1AB-1 - 4 oz. \#4022 M1lort Blue Per Gal. Vehicle

$1-1 \mathrm{BB}-2-6.5$ oz. M1-Pure R-610 Per Gal. Vehiole

1-MB-1 - 4 oz. \#4022 M10r1 Blue

$1-1 B-2-5$ oz. M1-Pure $\mathrm{R}-610$ Per Gal. Vehiole

$1-M B-1-402$. \#4022 M10r1 Blue

3-iB-2 - 3.5 oz M1-Pure R-610 Per Gal. Venicle

MB-2 - 4 oz 4022 M110r1 Blue

2 oz T1-Pure R-610 Per Gal. Vehiole

* T1-Pure R-610 is Rut1le non-chalking $\mathrm{T}_{2}$

Out of these three sets of panels, all having the same paint composition were put together for the determination of 0 degree, 45 degrees, apparent refleotence, on the Hunter Rerleotometer. These refleotanoe readings were taken in the following manner: 
The light source in the maohine was turned on and the refleotometer was allowed to warm up for about fifteen minutes. This precaution was found necessary because small changes in the temperature of the mechine caused a change in the reflecting surfaces thus giving an erroneous reading. Thls warming up of the instrument continued even after the first fifteen minutes, but the effeot was not mirked, howerer, constant care bad to be taken to keep the adjustments corresponding to the atandard used.

Stendards consisted of a sot of twelve motal plaques with magnealum oxide surfeces; each plaçu had a different value or degree of greyness. The plaques with a smaller dogree of greyness were used for light6r colors, while those with a lighter degree of greyness were used for deeper colors whioh refleoted less 11ght. The readings for Blue, areen, and Amber rilters were specified on each standard and the instrument was set corresponding to these readings and with the help of the sorew controlled the refleoting surface $M$ in rlgure 7, or by varying the apertures on the diso $\mathrm{E}$. The standard was replaced by the panel and the readings for $B$, A, G, fllters taken. Readings taken for each of the three filters were in the order $B, A$, and $O$. The reason for followIng this sequence was that the rerleotance is not very much with a blue filter hence the reading can be taken easily, without noving violently the mirror atteched to the quartz wire in the galvanometer. Otherwise stresses imperted to the 
wire might be released later on, when least expeoted; giving a ridioulous reading. To be on the safe side, before taking the final reading, the soale on the refleotometer was slowIy mored so that a rery amell current passed tinrough the galvanometer, shlfting the mirror slightly. By repeating this a couple of times it was insured that all the stresses in the wire were released.

Care was taken that there was no draft in the room, which might ohange the temperature of the instrument. Probably the heating up of the instrument had some effeot on the photocells, There are some absorbed as well as adsorbed gases on the elements of the photooells, which are giren off en heating, thus changing the nature of the atmosphere of the cell.

If this phenomenon was taking place then it is erident that an equilibrium was reached after some tine because after cortain time the readings remained constant. As has been explained before different sized apertures are provided in the lastrument for the light passing on to the gloas cell. The size of the aperture had to be decreased sometimes to out out some of the l1ght going to the gloss cell.

In this way the readings for all the panels were taken and out of the three presumably ldent1cal panels, two having the same or nearly the same readings were separated. In this way two sets of thirty panel each were obtained. 
One of these sets was kept for future referenoe and the panels in the other were exposed to the ultra violet 11ght in the weathoring unit. The exposure was dry and was for about vwelve hours at a time, although it had to be increased to twenty four hours as the ohange in the refleotanoe beoame small.

Aotually the exposed panels were divided into two sets of Iffteen each and one set was exposed wh11e the other was being measured for 0 degrees, 45 degrees apparent refleotanoe. After each exposure the panels were allowed to come to room tempexature before the readings were taken. Also care was taken that panels were inserted in the refleotometer in exactly the same position, every time. This prooedure was continued $t 111$ ell the panels had been exposed for about three hundred hours.

Readigs of the refleotometer are given in the appendix. A sample calculation 1 ahown in Table I. for the panel 2-PB-1, 3-PB-2. The rest of the caloulations have been omltted and only the calculated results heve been shown in the Tables II to XVII.

$$
\begin{aligned}
& \text { B' - Change in Hue } \\
& \text { S' - Change in Saturation } \\
& \text { L' - Change in Brightneas }
\end{aligned}
$$

Thewe vaiues of Brightness, Saturation and Hue have been plotted with respeot to exposure tine in the Graphs in I1gure 1-28, ghowling the general trend of the 
qualities of a oolor. From experience and general observations an empirical equation has been developed by the paint industry; correlating hue, brightness, and saturation.

where

$$
\begin{aligned}
& \text { Permanence }=40+2 S+H \\
& a=\text { Greyness or Brightness }
\end{aligned}
$$

$$
\begin{aligned}
& S=\text { Saturation } \\
& \text { H = Hue }
\end{aligned}
$$

It has been found that as long as the sum of these three terms of the equation 18 less than ten, the oustomer will not object to the change in oolor. But when this value goes beyond fifteen then the ou stomer can easily notice the change in color and will objeot to it. The above mentioned equation is true for darker colors, beoause the change in fiue is not objected to as much as the change in Brightness. On the other hand in case of jellows, the change in Hue is considered undesirable even though there may be considerable greying. As a rule customers do not like yellow golng towards red or green. Hence for yellow plgments the equation should be modifled and becomes,

$$
P=40+S+2 H
$$

In both oases when the value of $s$ is positive, it should be omitted. Thue by ploking velues of $G, S$, and H from the curves, values of permenenoe can be calculated and rate ourve oan then be drawn, as is shown in flgure 29, the data for whioh is given in table XXVIII. 
Three panels have been selected for this table namely $P B-1, P B-2$, and a $1: 3$ mixture of the se two plgments. From the curres on page 84, It can be seen that up to about 150 hours the individual plgments have tendenoy to change at ate which is less than that of the mixture. However, after 200 hours the permanenoe rate of the mixture becones comparable to that of the individual pigment. Anyway, the final permanence value, in all three casos, is well within the limiting value of ten. In this serles of Blues the panel with the mixture 1-PB-1, 1-PB-2, hes not been considered as the value of $S^{\prime}$ and $F^{\prime}$ were too Wh to be correct, ovidently there was some exror in the original readings of the rerleotometer.

These rate curves could be drawn for the rest of the plgment but this long prooedure is unnecossary for the present purposes. A more convenient and quite adequate way Is to simply determine the Permanence after 300 hours and see whether it is below ten or not. Permanence values have been calculated for the rest of the panels and given in the table $\mathbf{x x D x}$. 


\section{TABLE II}

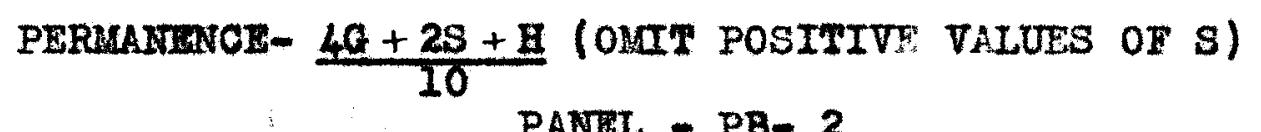

$$
\text { PANEL - PB- } 2
$$

$\begin{array}{ccccc}\text { Ers. } & \text { G. } & \text { s. } & \text { H. } & \text { Rate } \\ 25 & -1.2 & 0.0 & 2.6 & 0.74 \\ 50 & -1.4 & 0.0 & 4.2 & 0.98 \\ 75 & -1.6 & 0.0 & 5.0 & 1.14 \\ 100 & -1.6 & -1.6 & 5.3 & 1.49 \\ 125 & -1.6 & -3.2 & 5.6 & 1.84 \\ 150 & -1.2 & -4.8 & 5.9 & 2.03 \\ 175 & -0.4 & -6.4 & 6.0 & 2.04 \\ 200 & 0.0 & -8.0 & 6.0 & 2.20 \\ 225 & 0.0 & -9.6 & 6.0 & 2.25 \\ 250 & 0.0 & -4.2 & 6.0 & 2.84 \\ 275 & 0.0 & -12.6 & 6.0 & 3.12 \\ 300 & 0.0 & -13.4 & 6.0 & 3.28\end{array}$


TABLE II (oont'd)

$$
\text { PANEL - PB-1 }
$$

Hrs

s.

H.

Rate

25

0.0

2.4

1.6

0.16

50

0.0

3.6

4.6

0.46

75

1.2

3.4

6.4

1.12

100

2.4

2.6

7.0

1.26

125

1.6

0.2

7.6

1.44

150

1.8

2.0

7.8

1.90

175

1.9

3.6

7.8

2.26

200

2.0

5.4

7.8

2.66

225

2.2

7.2

7.8

3.10

250

2.4

8.8

7.8

3.50

275

2.6

10.4

7.8

3.90

300

2.8

12.0

7.8

4.70 
TABLE II (oont 'd)

PAKEI 1-PB-1 3-PB-2

$\begin{array}{lllll}\text { HrE } & 0 . & 3 . & \text { H. } & \text { Rato } \\ 25 & -2.0 & -0.4 & 2.0 & 0.16 \\ 50 & -2.4 & -1.0 & 3.8 & 0.46 \\ 75 & -2.7 & -2.4 & 4.2 & 1.22 \\ 100 & -2.8 & -1.9 & 4.6 & 1.26 \\ 125 & -3.2 & -2.4 & 5.0 & 1.44 \\ 150 & -3.3 & -2.8 & 5.4 & 1.90 \\ 175 & -3.5 & -3.2 & 5.7 & 2.26 \\ 200 & -3.6 & -3.6 & 6.0 & 2.66 \\ 225 & -3.7 & -4.0 & 6.4 & 3.10 \\ 250 & -3.8 & -4.5 & 6.8 & 3.50 \\ 275 & -3.9 & -5.0 & 7.2 & 3.90 \\ 300 & -4.0 & -5.5 & 7.7 & 4.70\end{array}$




\section{TABL XXIX}

\section{PRRUAKEWCE RATTHO}
4. $\begin{array}{r}1-R-5 \\ 2-R-3\end{array}$
$0.88+9.5+0.5=10.84$
5. $\mathrm{MB}-5$
$0.80+9.2+0.5=10.5$
6. $\quad 1 B-1$
$2.0+28+3=33.0$
7. $118-2$
$0.4+72+5.2=77.6$
B. 1-19-2
$2.0+-31.6+5.4=39.0$
9. $1-1 \mathrm{~B}-1$
$4.0+28.0+6.0=38.0$
10. $\frac{1-1 \mathrm{~B}-1}{3-18}$
$2.4+29.2+5.4=37.0$
11. $0-2$
$0.0+9.4+1.7=11.1$
12. $0-3$
$5.2+-3.0+1.4=9.6$
13. $\frac{1-0-1}{1-0-2}$
$1.2+-8.8+1.5=11.5$
14. $0-4$
$0.0+10.0+1.7-11.7$
15. $0-1$
$0.8+13.6+2.8=17.2$
16. $Y-1$
$47.2+-18.0+0.6=71.2$
17. $\frac{1-Y-1}{1-Y-2}$
$30.4+-1.0+1.5=32.9$
18. $T-2$
$40.4+5.0+0.0=45.4$
19. $\frac{1-Y-3}{1-Y-2}$
$34.4+-4.2+0.3=38.9$.
20. $\mathrm{x}-3$
$16.0+4.2+4.0=24.2$ 


\section{TABLI XXIX (oont'd)}

$$
\begin{aligned}
& \text { 21. } 0-1-0.4+-20.6+5.3=26.3 \\
& \text { 22. } 0-3-4.0+15.6+-2.2=21.8 \\
& \text { 23. } \begin{array}{l}
1-0-2-0.4- \\
2-0-3
\end{array}-0.4+19.6+-2.0=22.0 \\
& \text { 24. } \begin{array}{l}
2-\theta-2 \\
1-0-3
\end{array}-4.4+19.0+2.7=26.1
\end{aligned}
$$




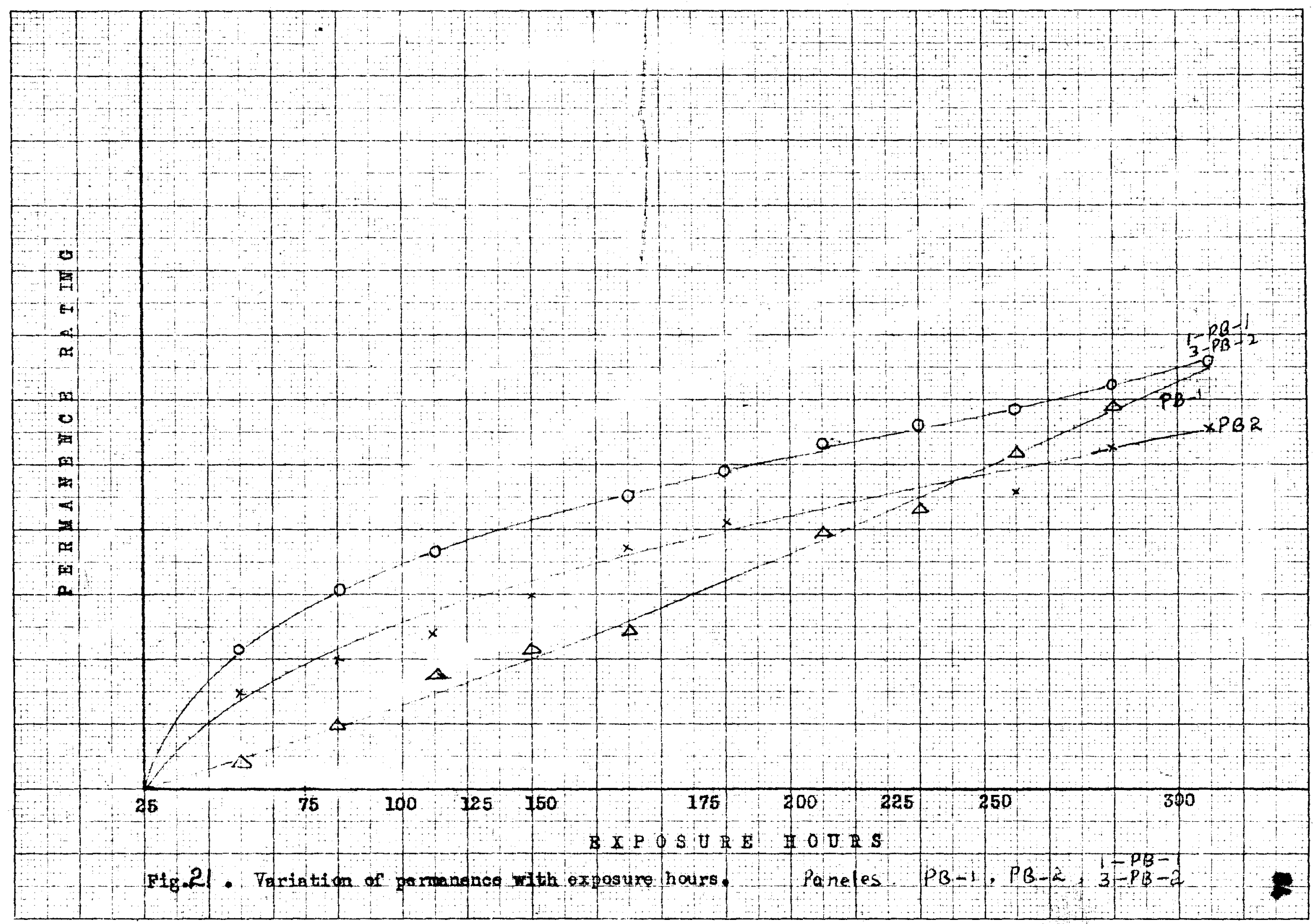


The reaults of the abore oaloulation show that with the exception of panels number 4, 5, 11, 12, 13, and 14 of rable uumber XxIX the other panels have exceeded the permanenoe limit but permanenoe values of panels number 7 . 16, and 18 are too high to be true, Indioating some error in orleinal readings.

The ourres for panel R-5 show that there is an Inorease in saturation $s^{\prime}$ orer the original color whioh is quite desirable.

In the I serles the results for the panel 1-I-2, 1-Y-3 are Intermediate botween those of $Y-2$ and $Y-3$. The saturation, hue, and brightness ourves for $Y-1$ again seem to be off. Probably the initial readings wore inoorreot. 


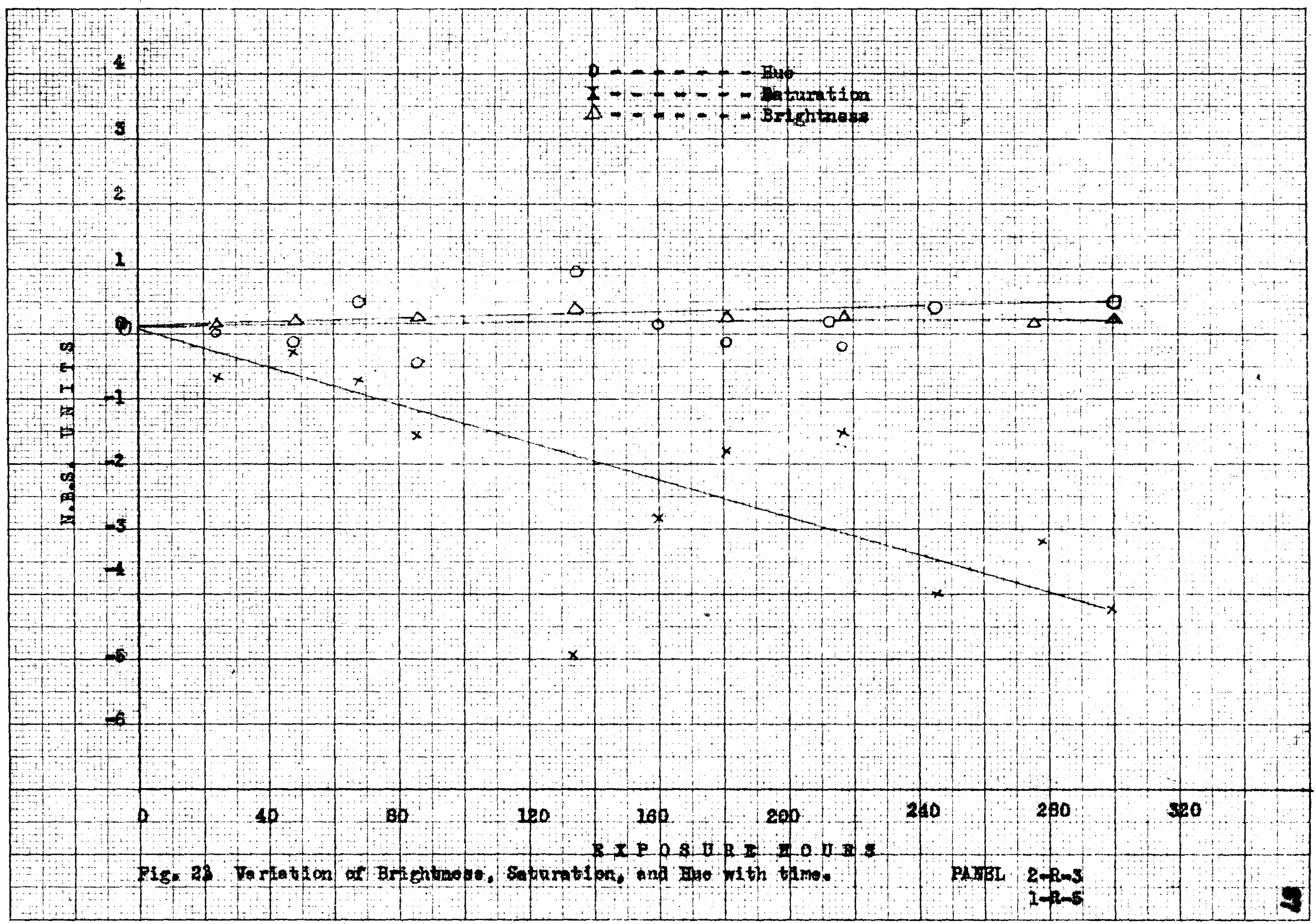




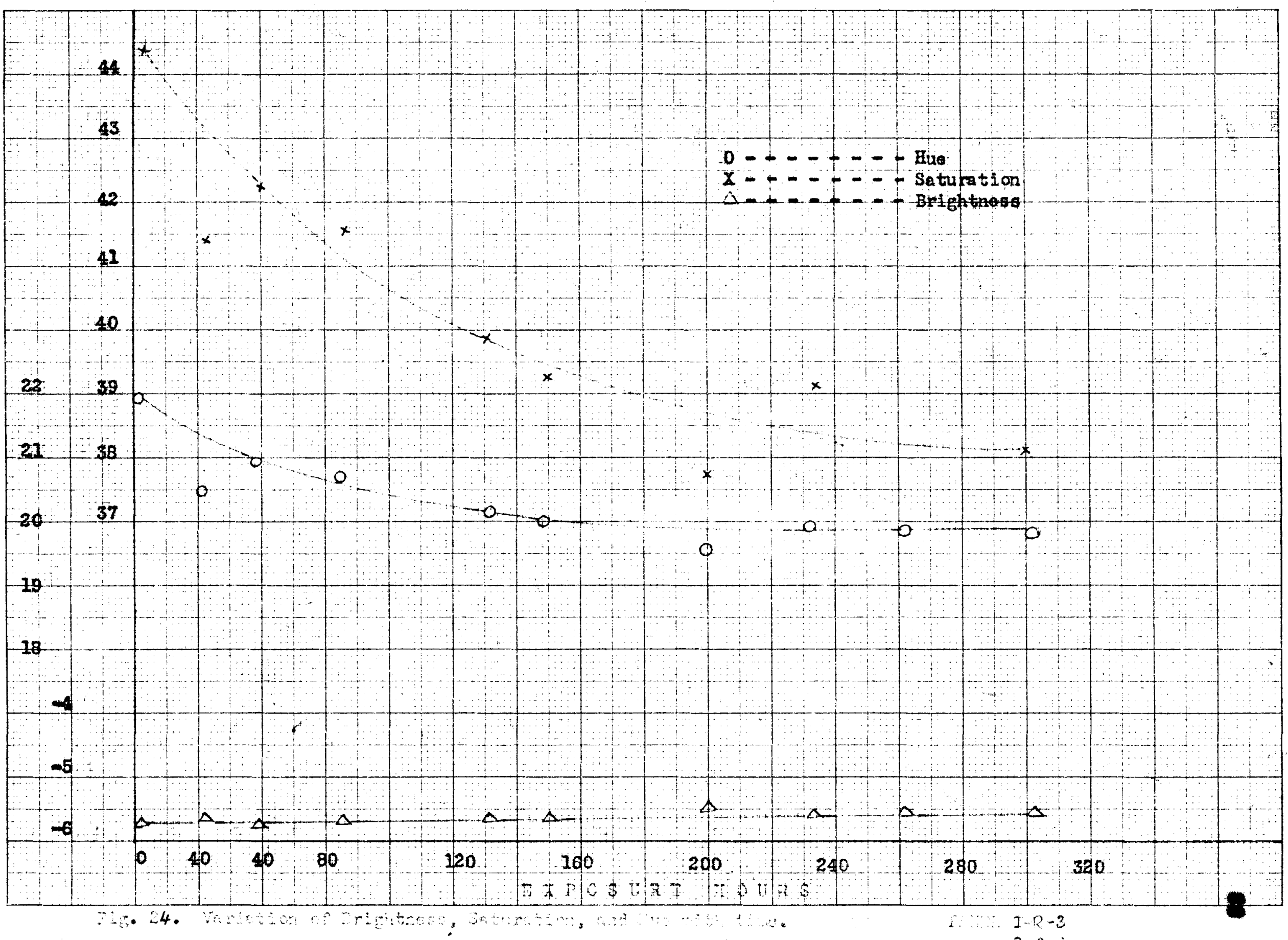




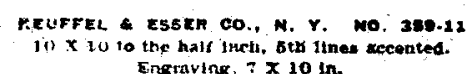

Engraving $\div \times 10$

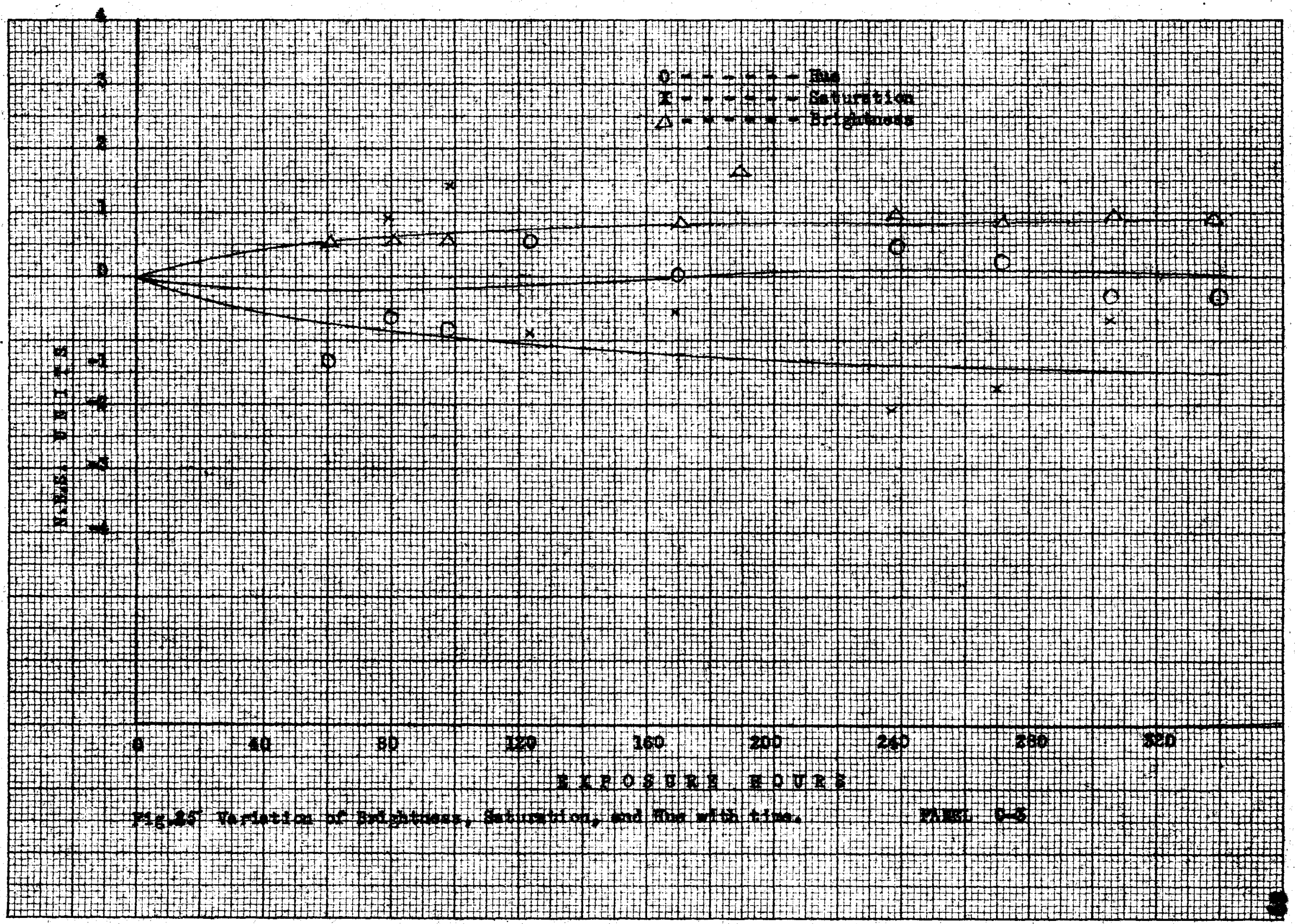




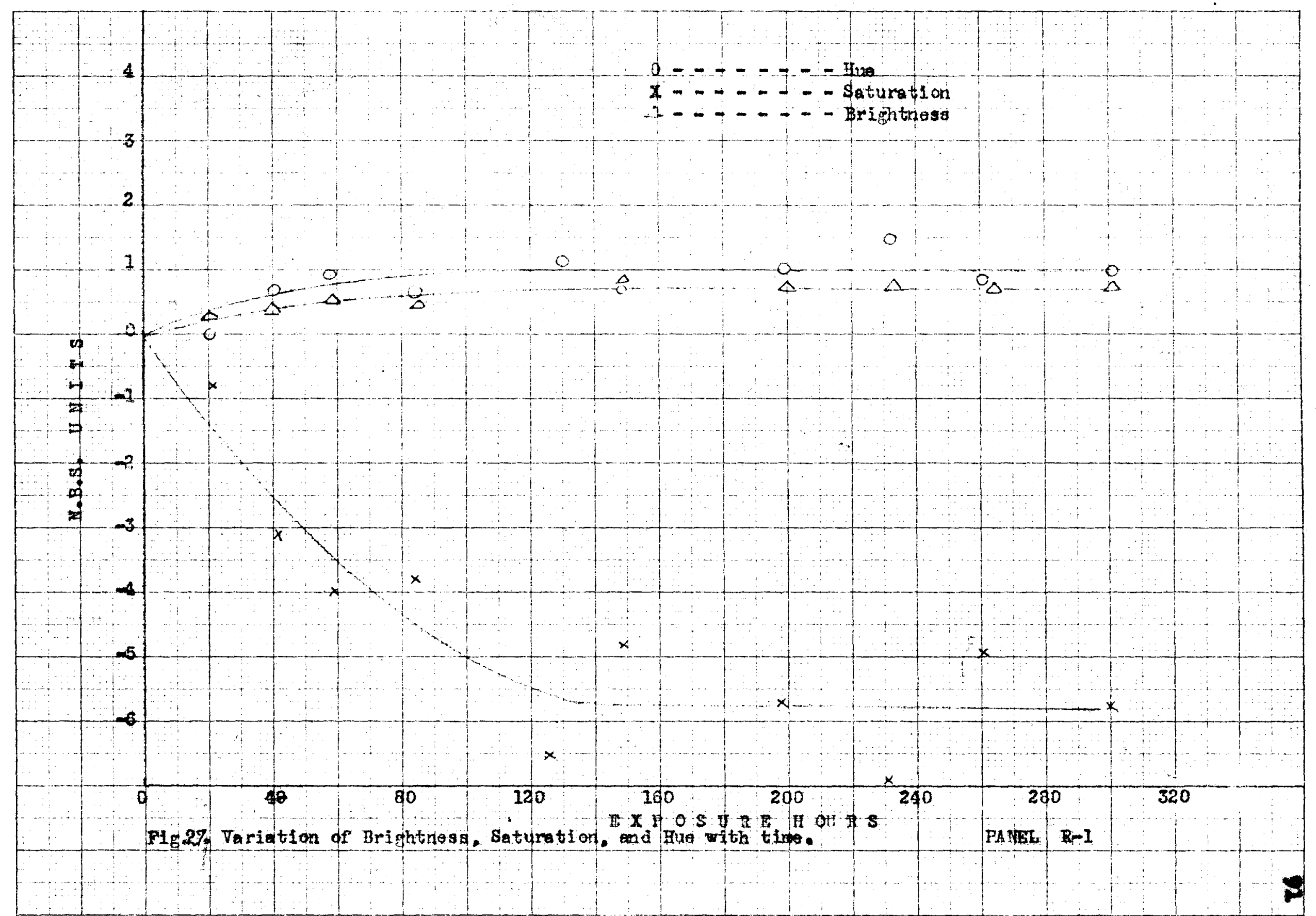




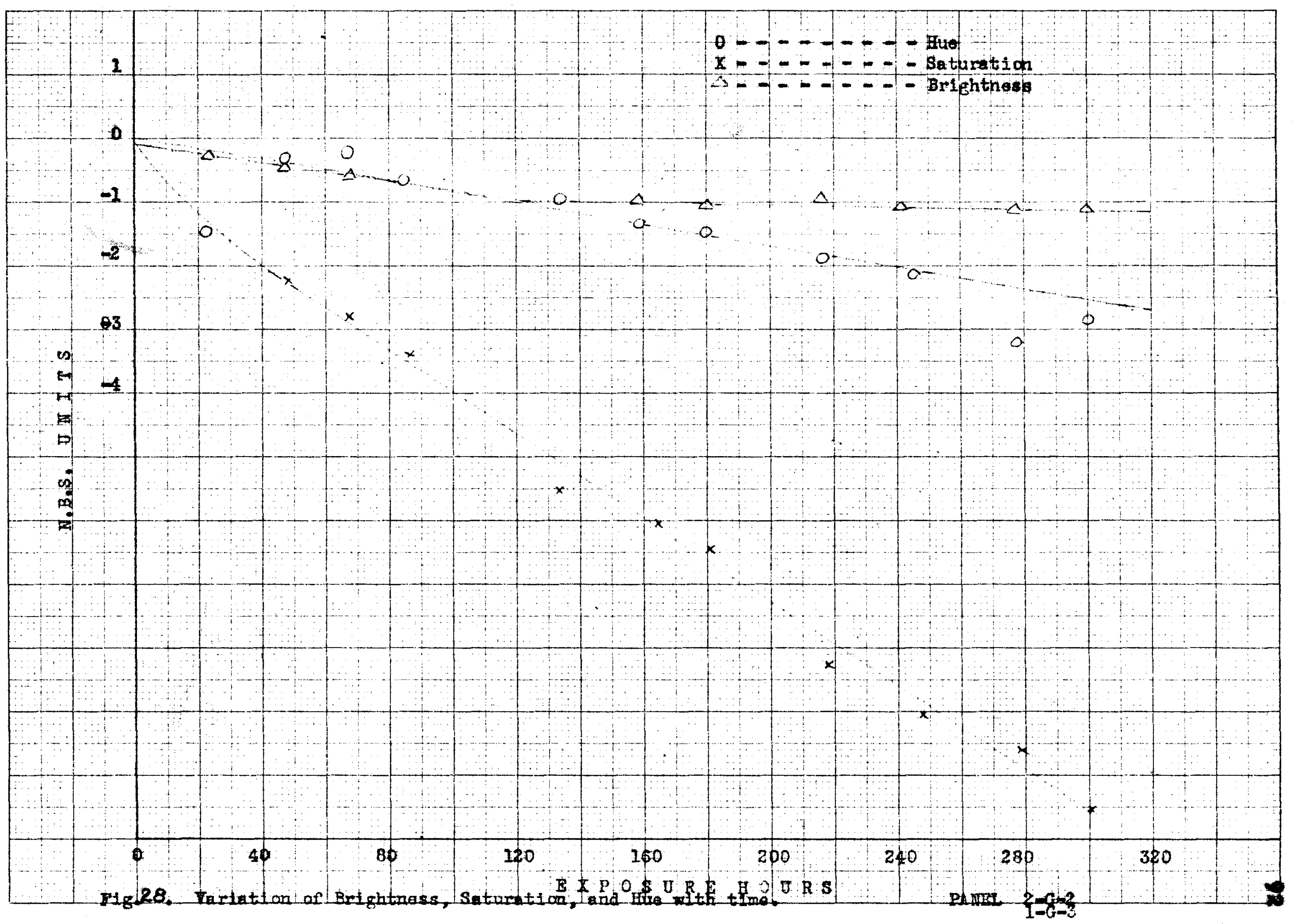




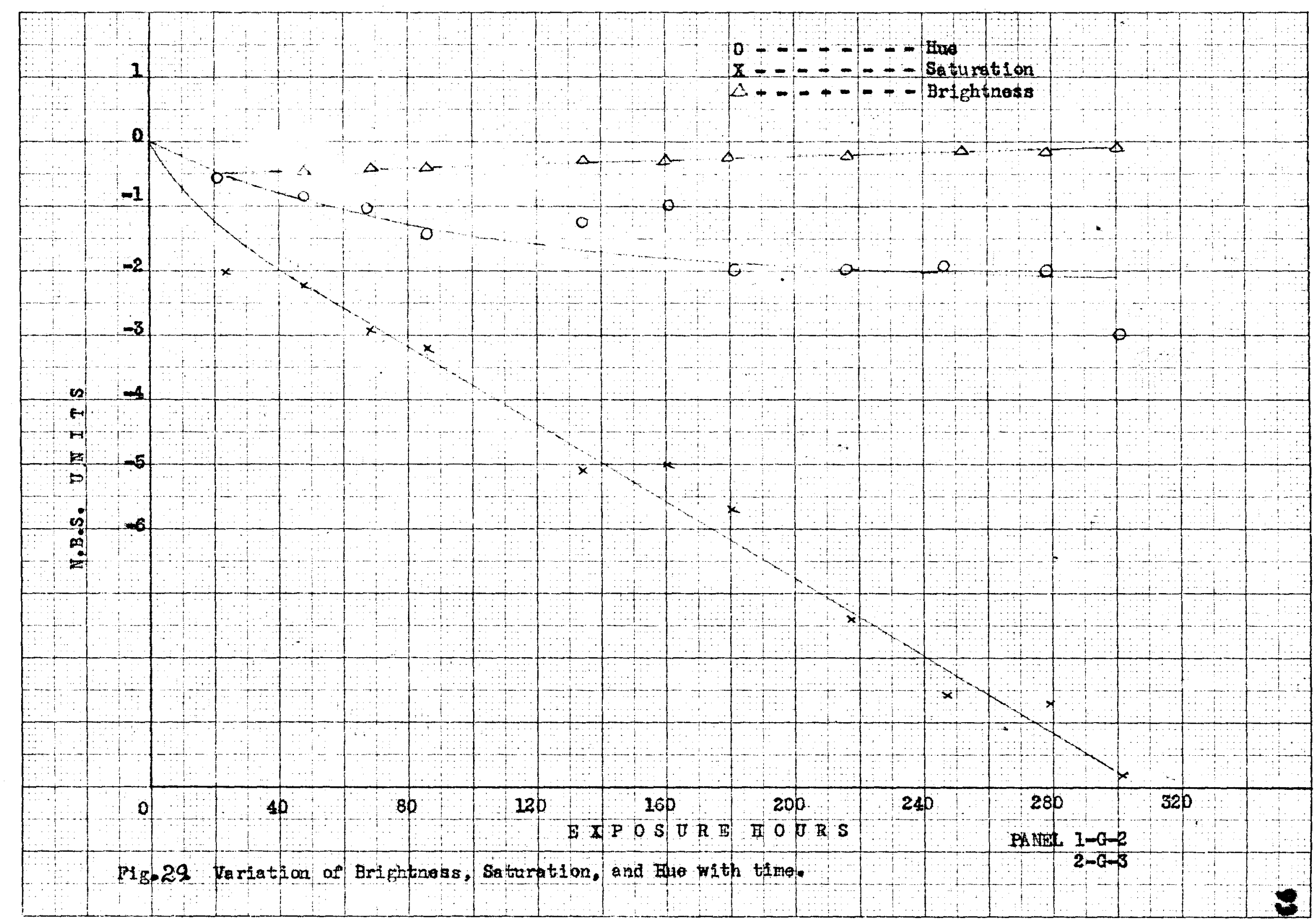




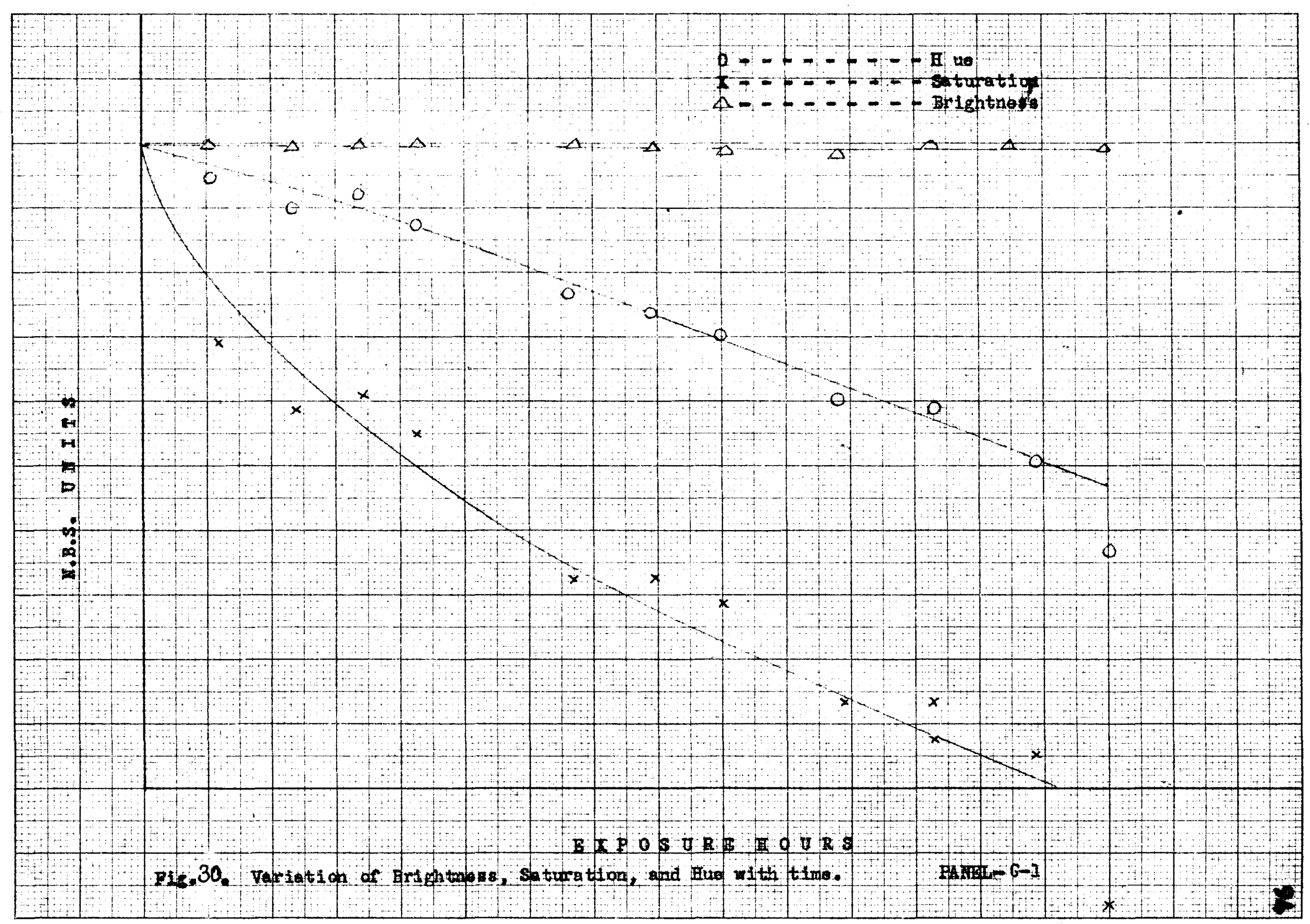




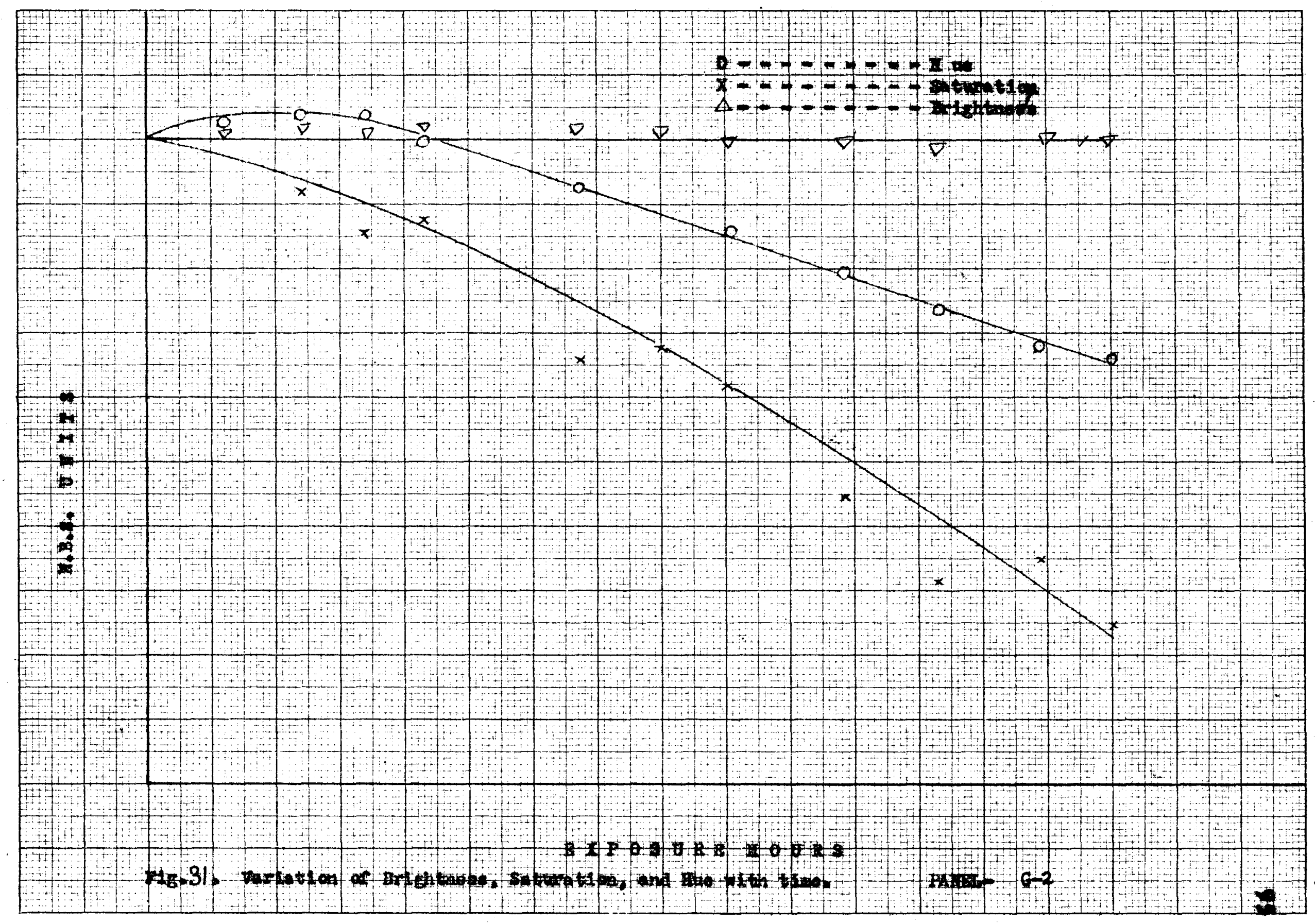




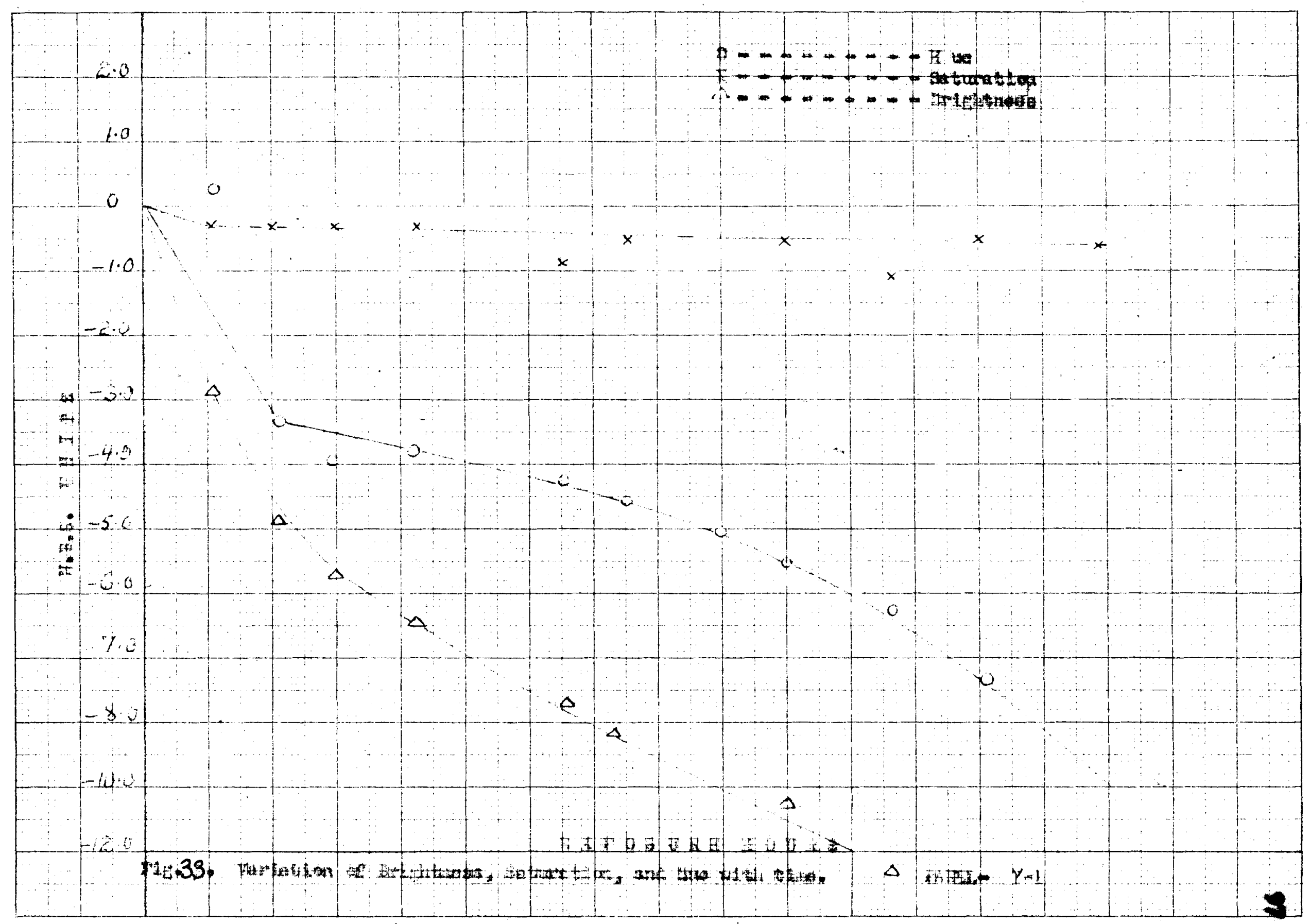




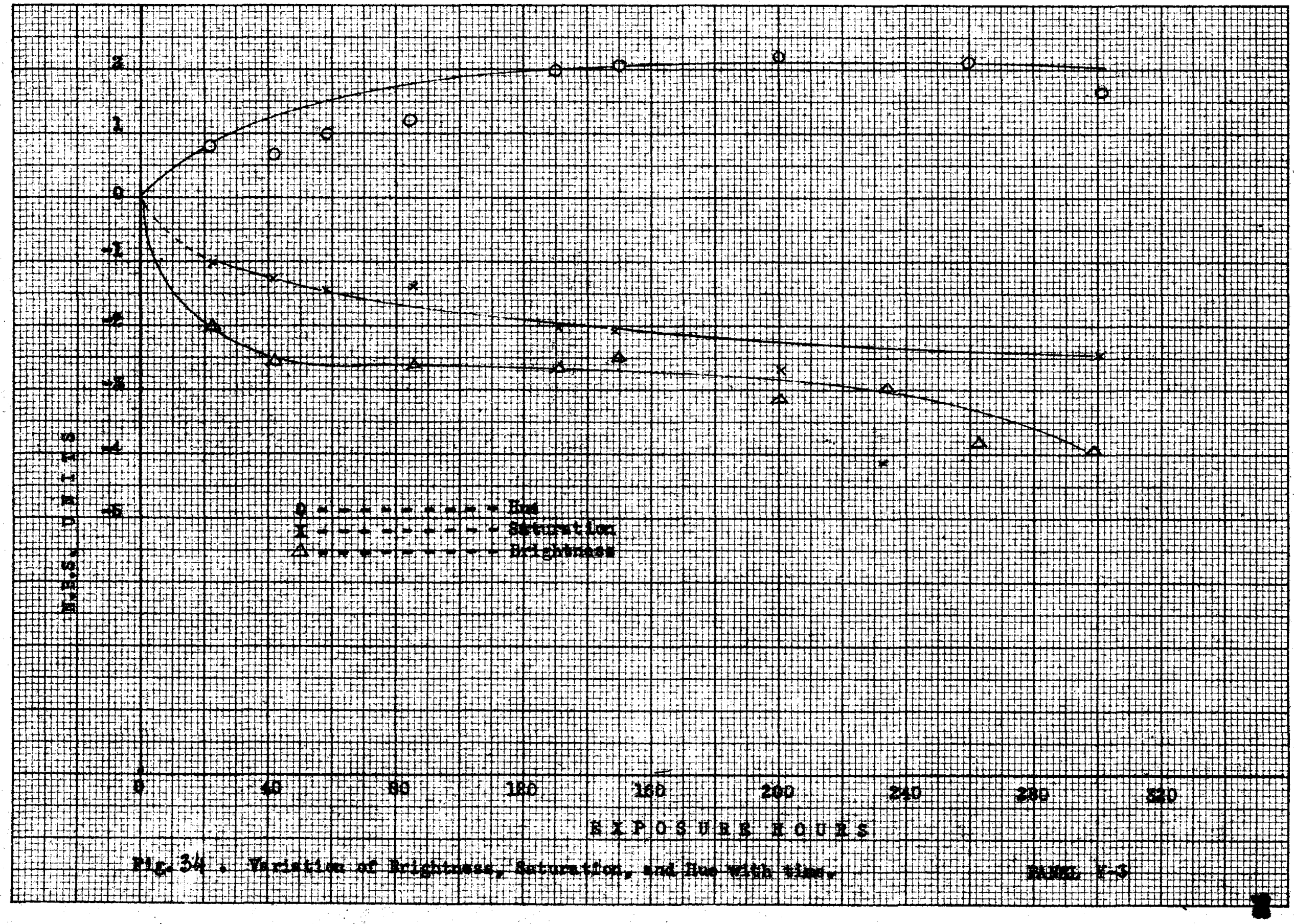




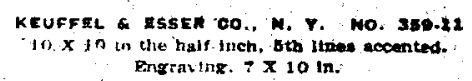

जite is J.s.A.

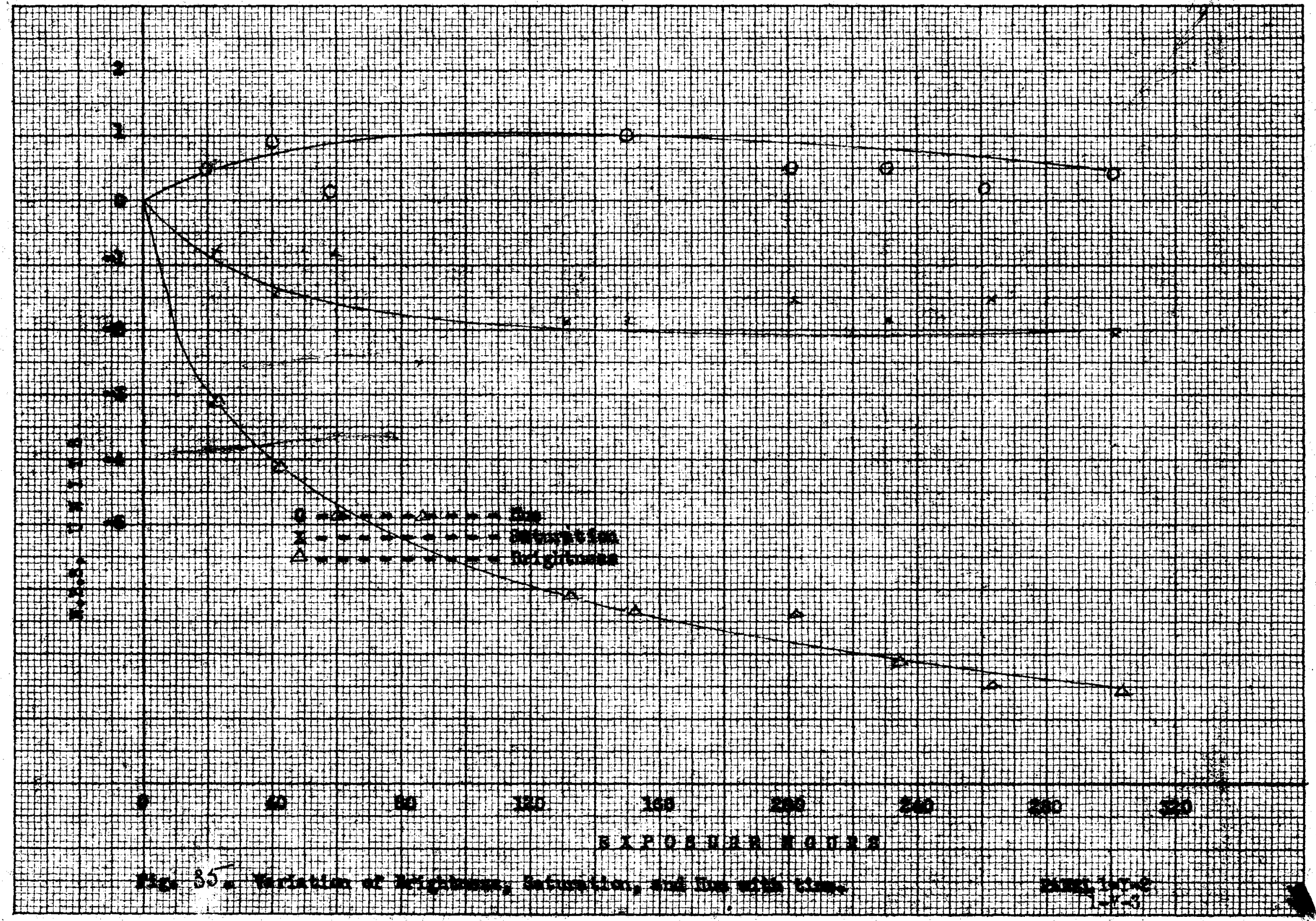




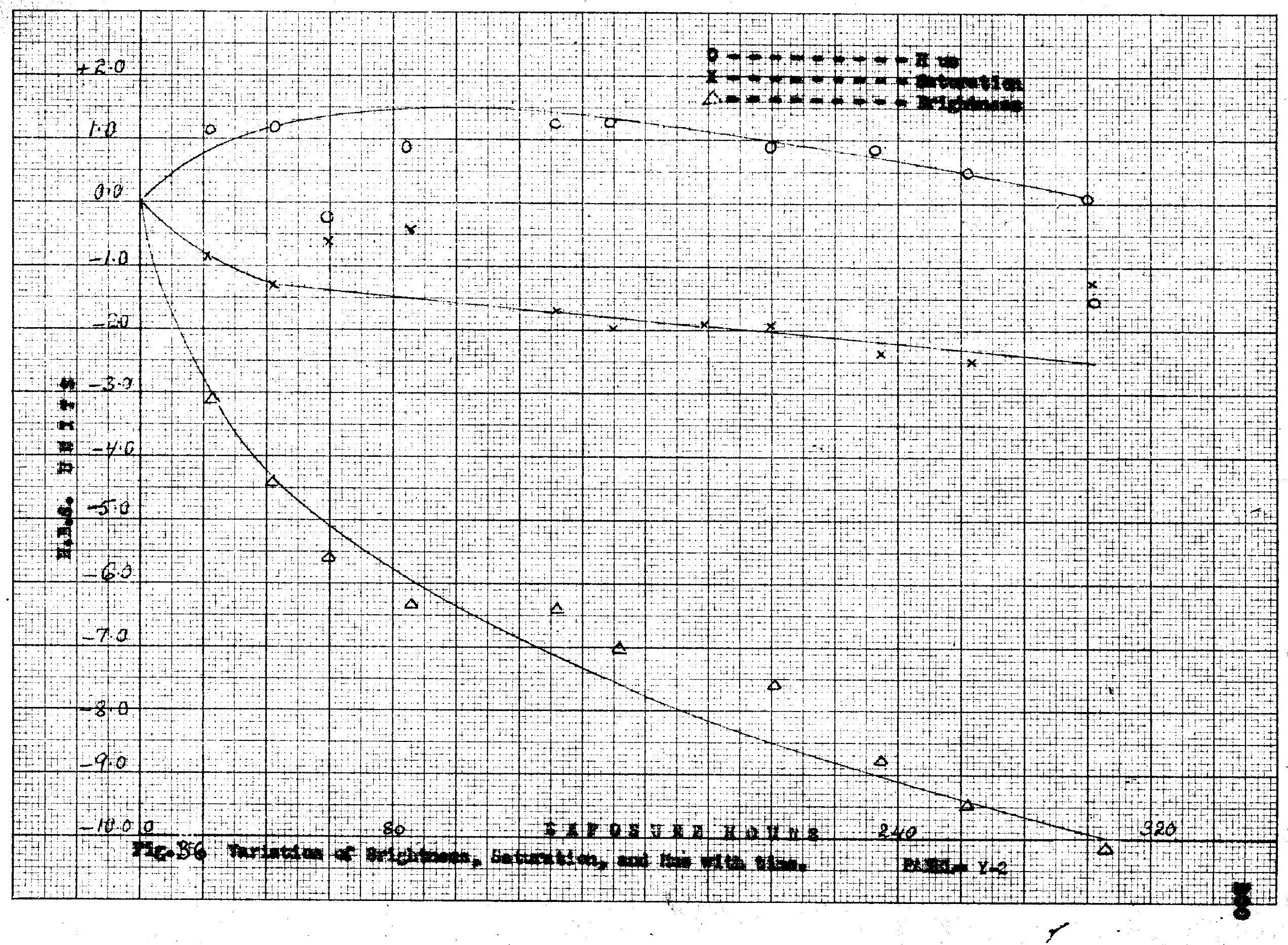




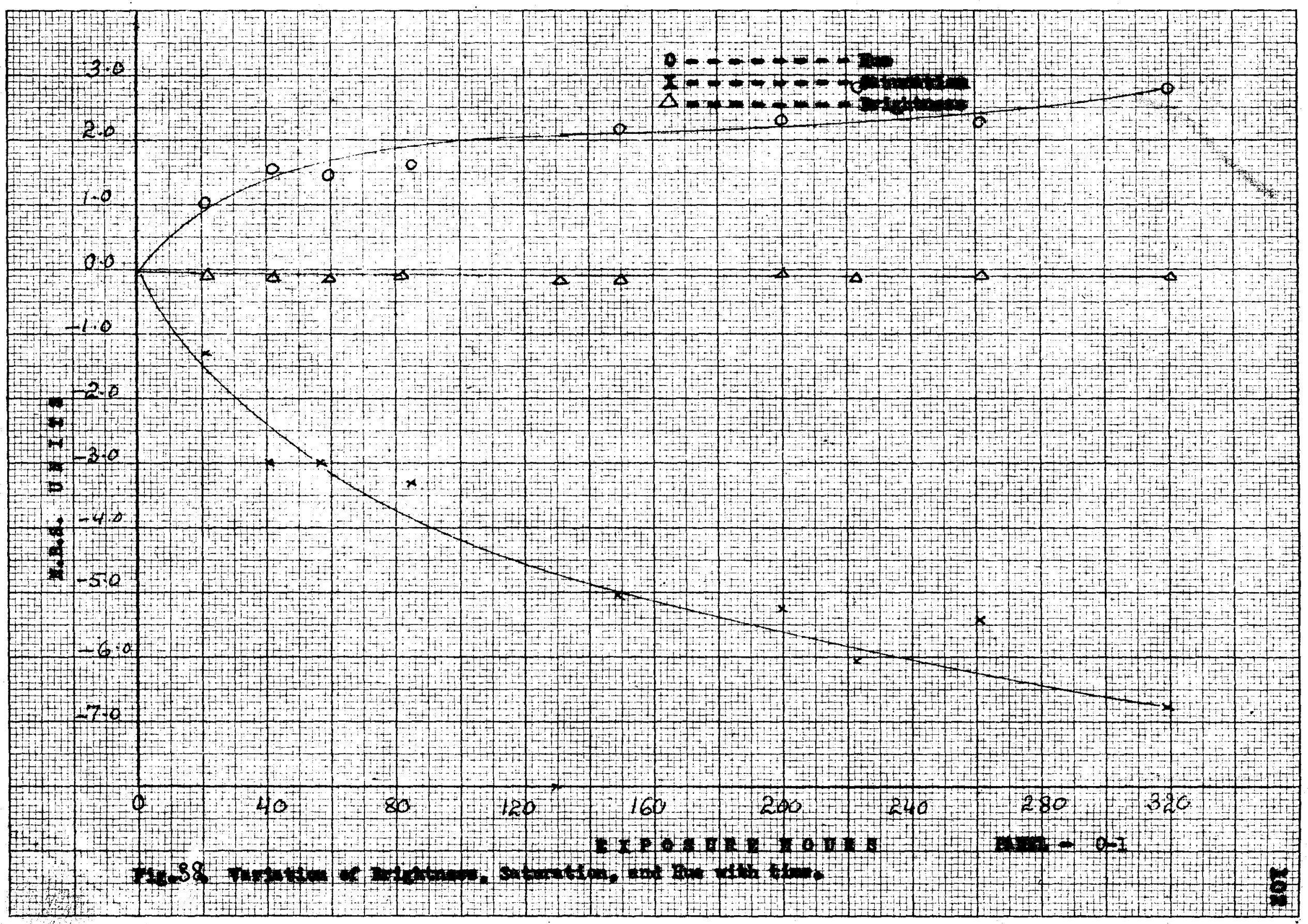




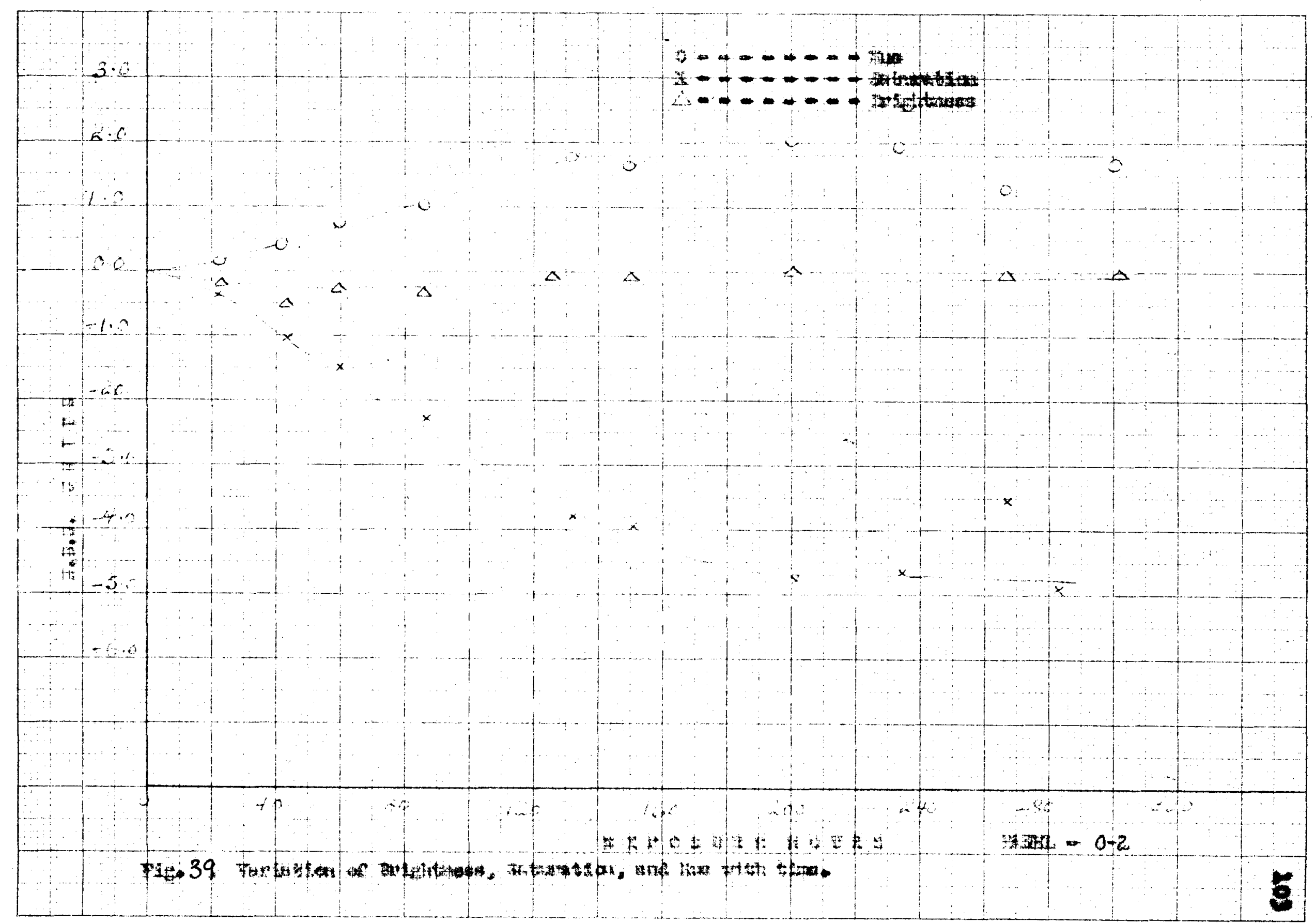




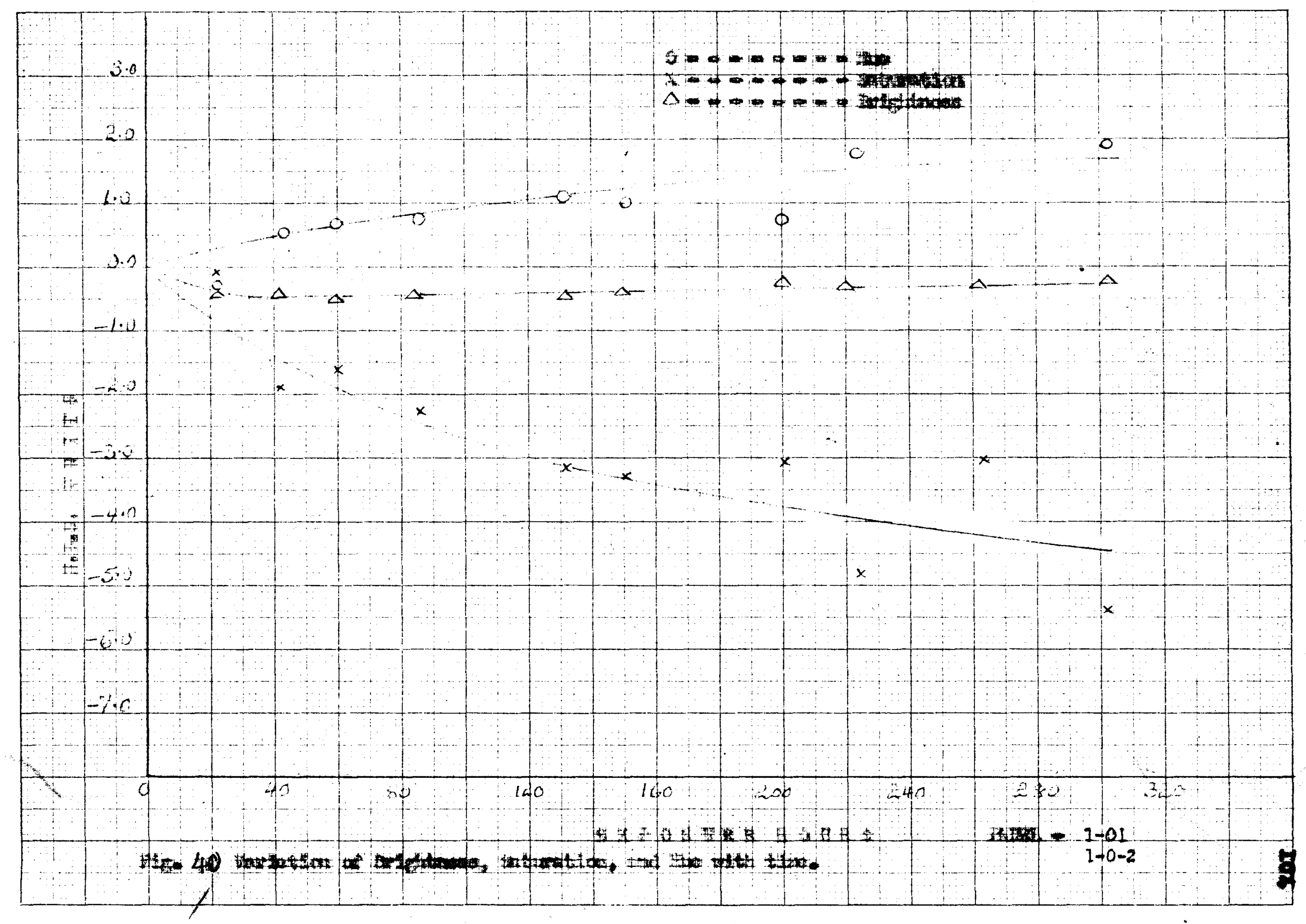




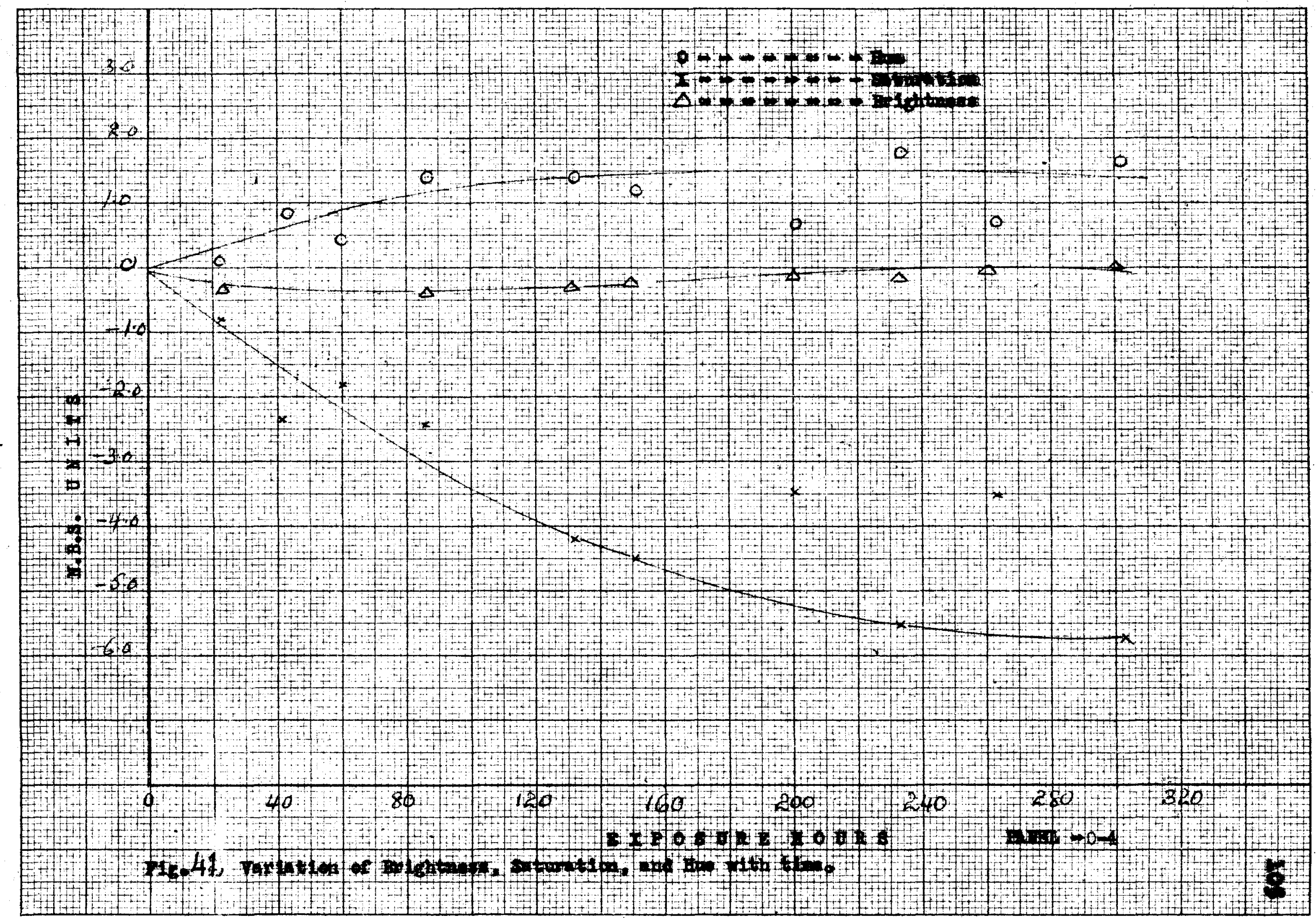




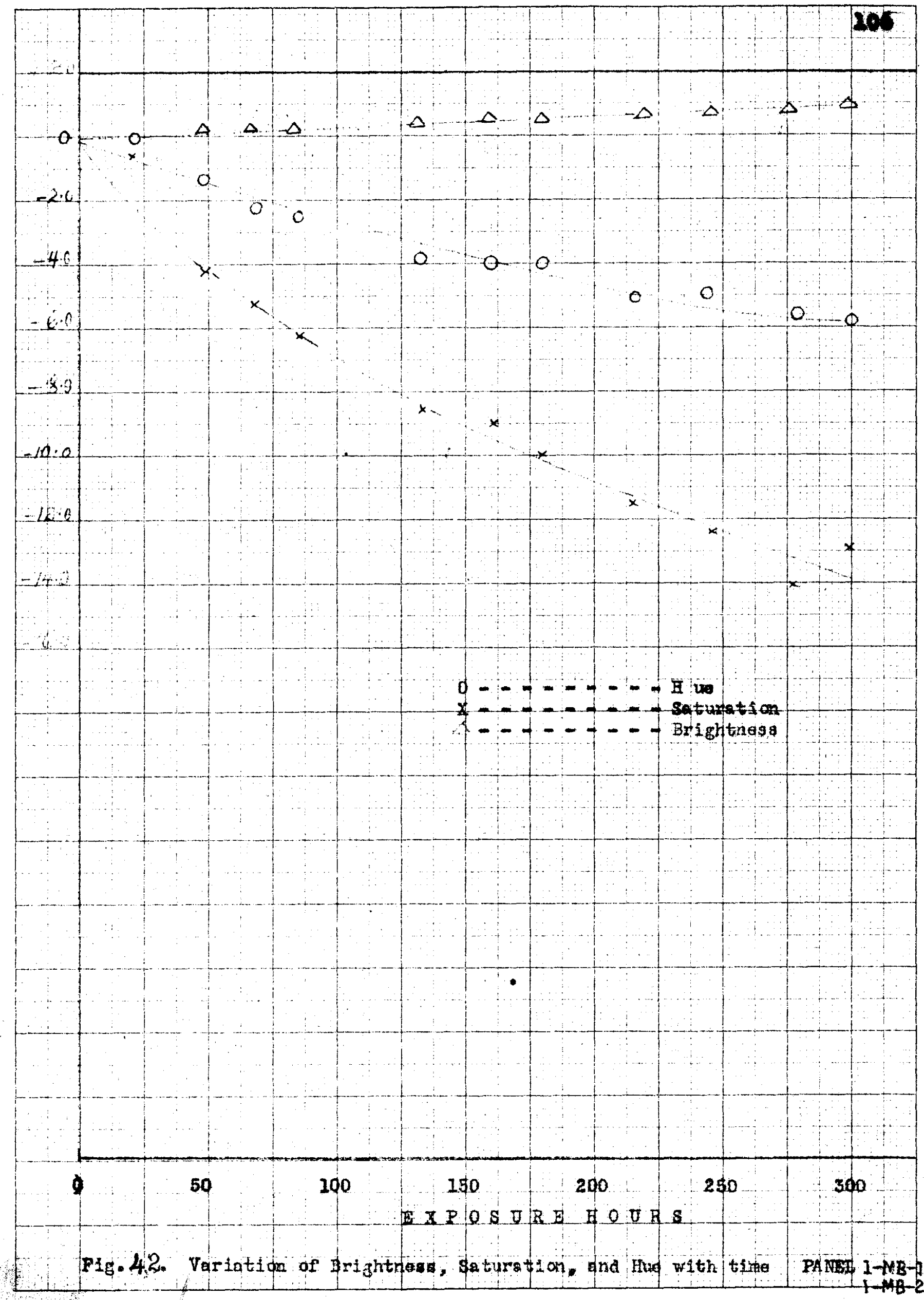




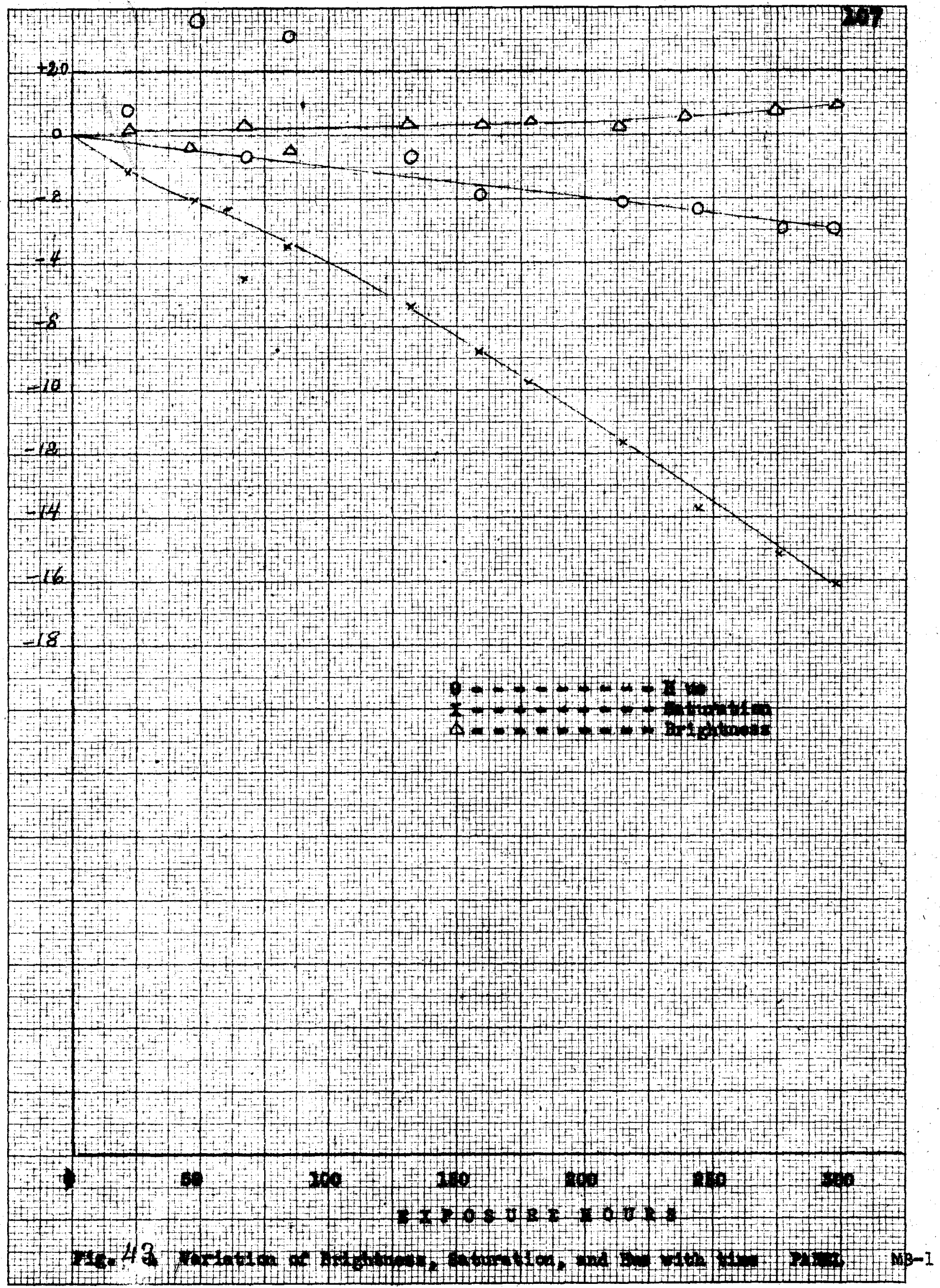




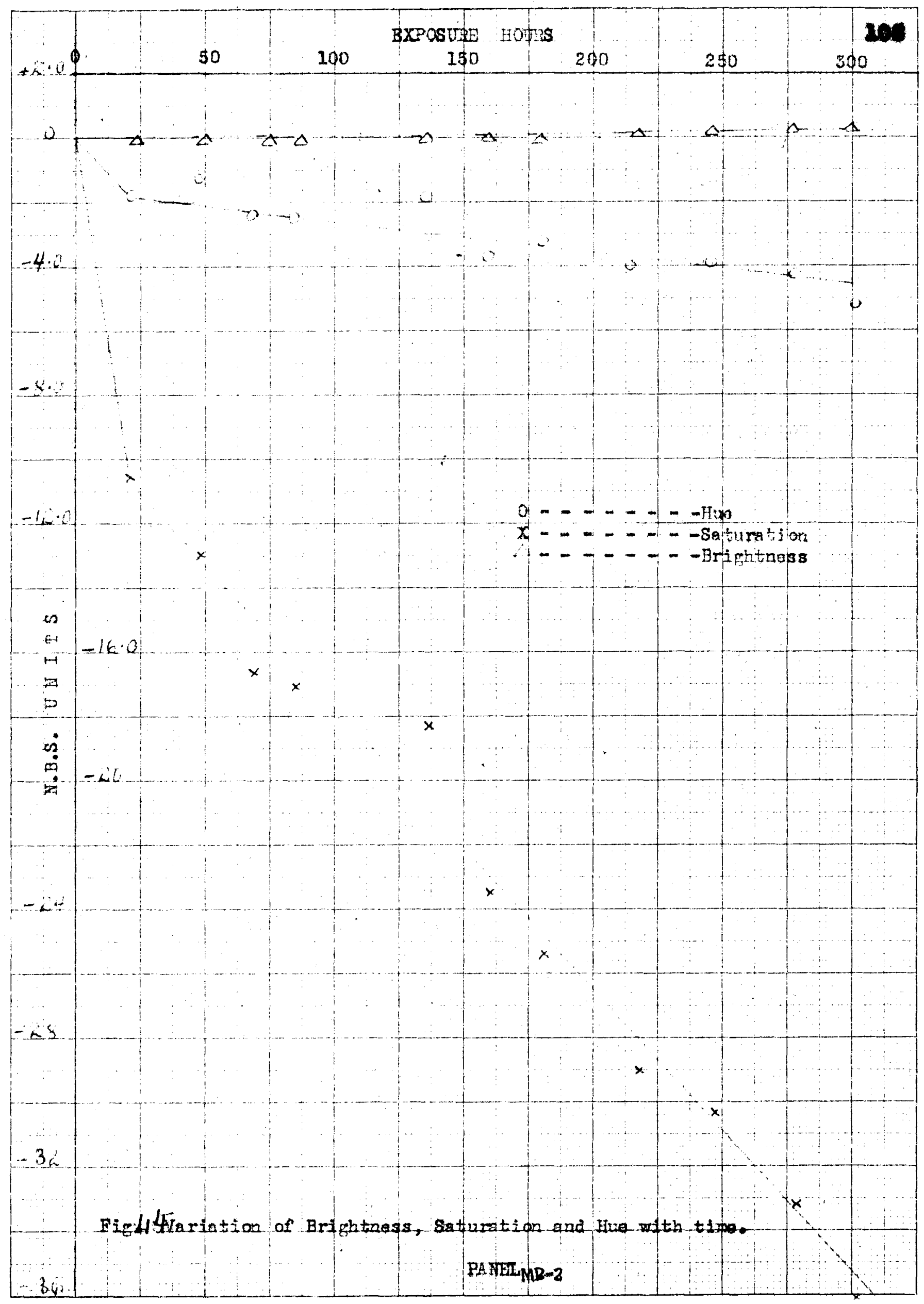




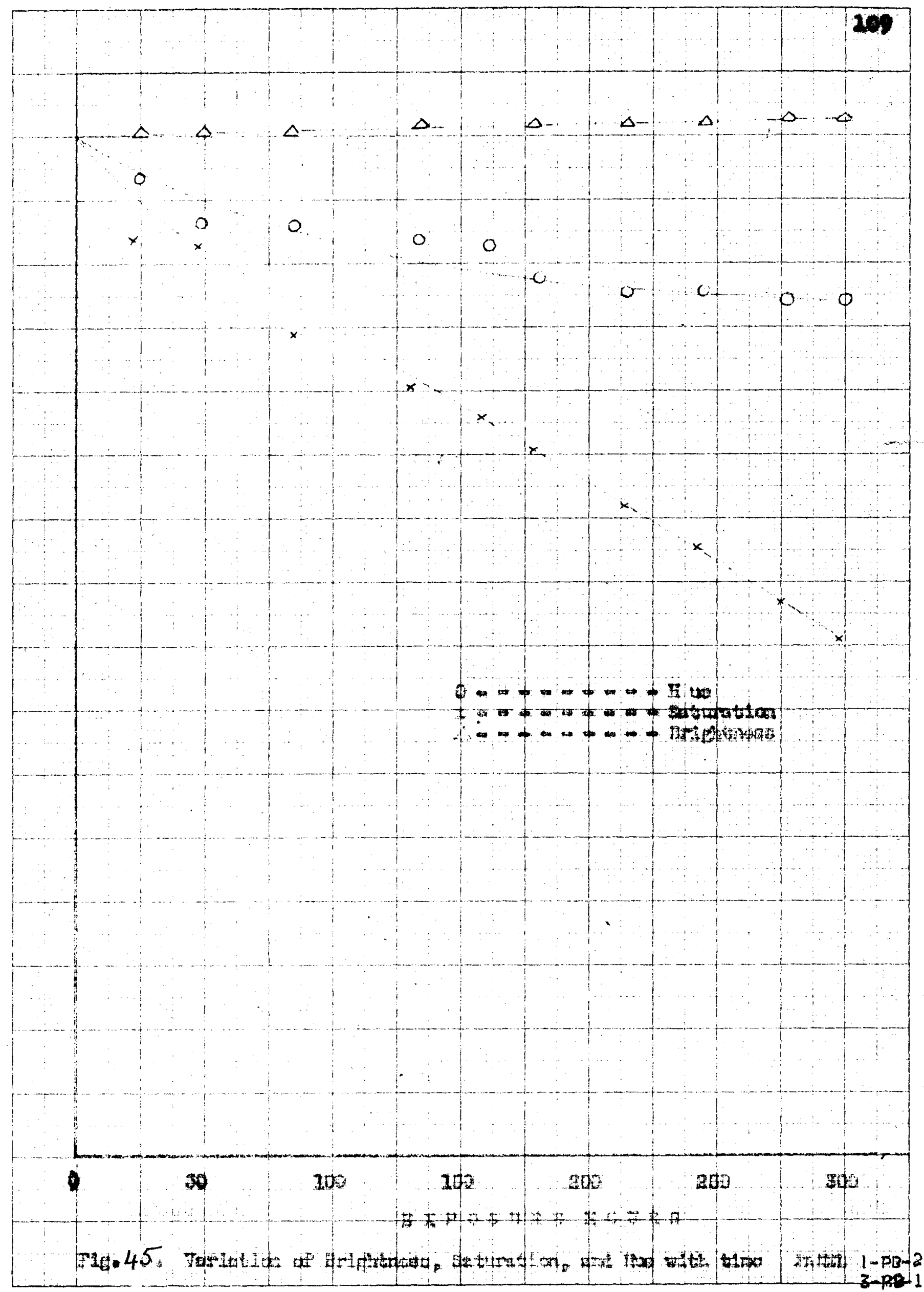




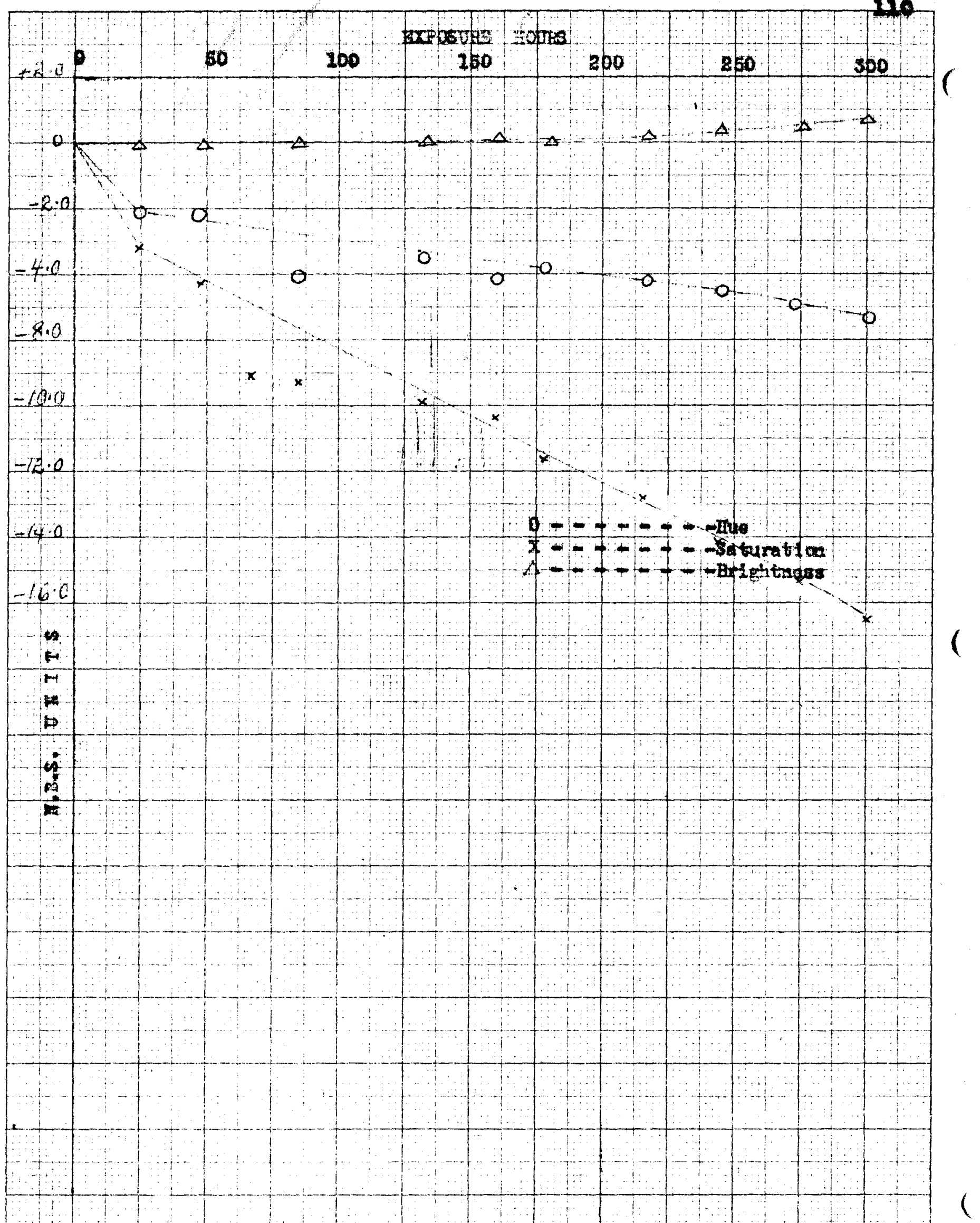

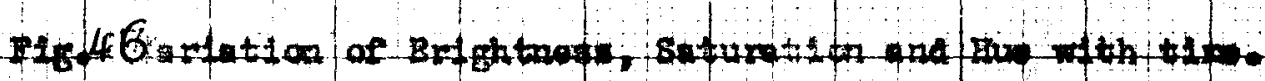




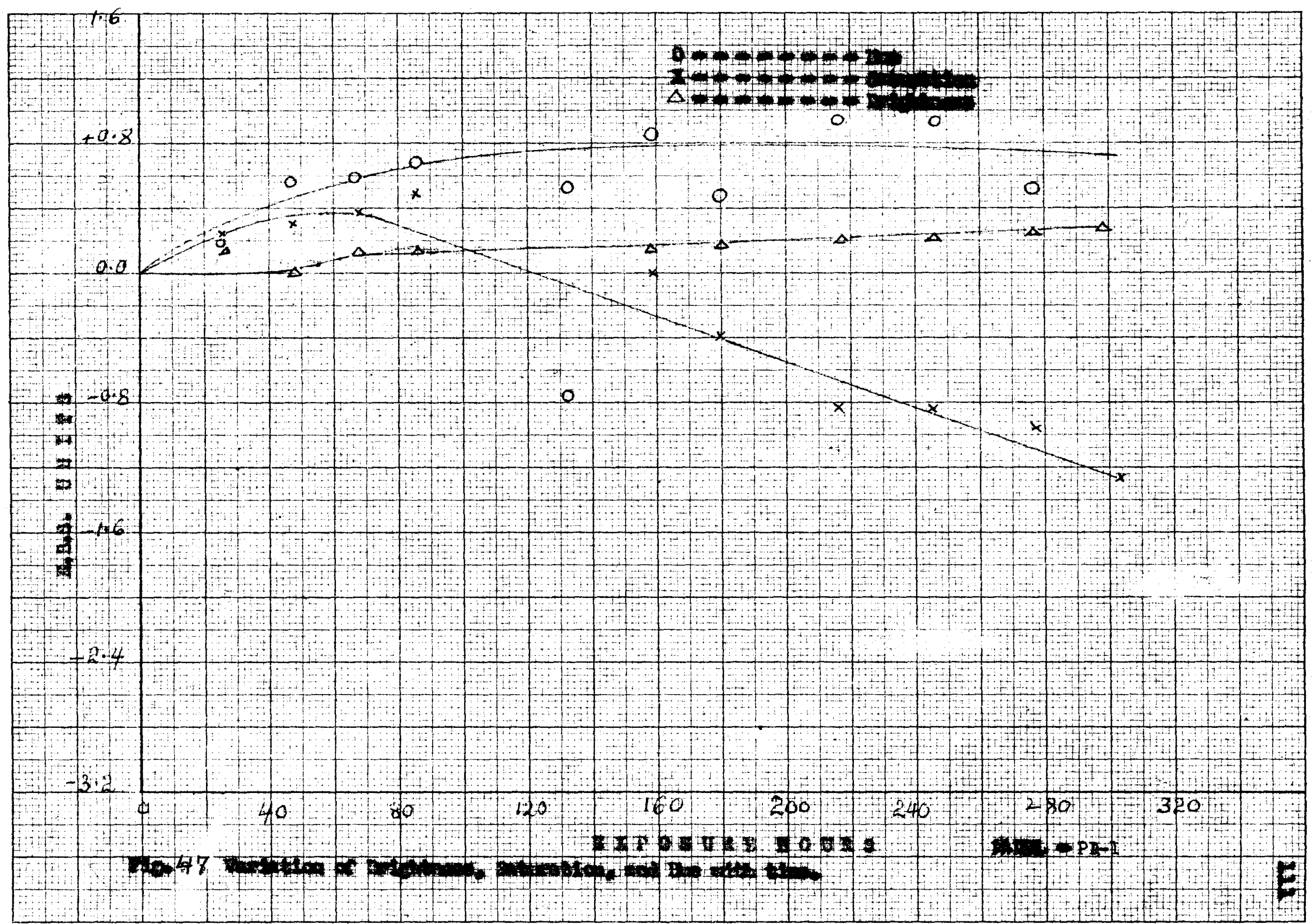




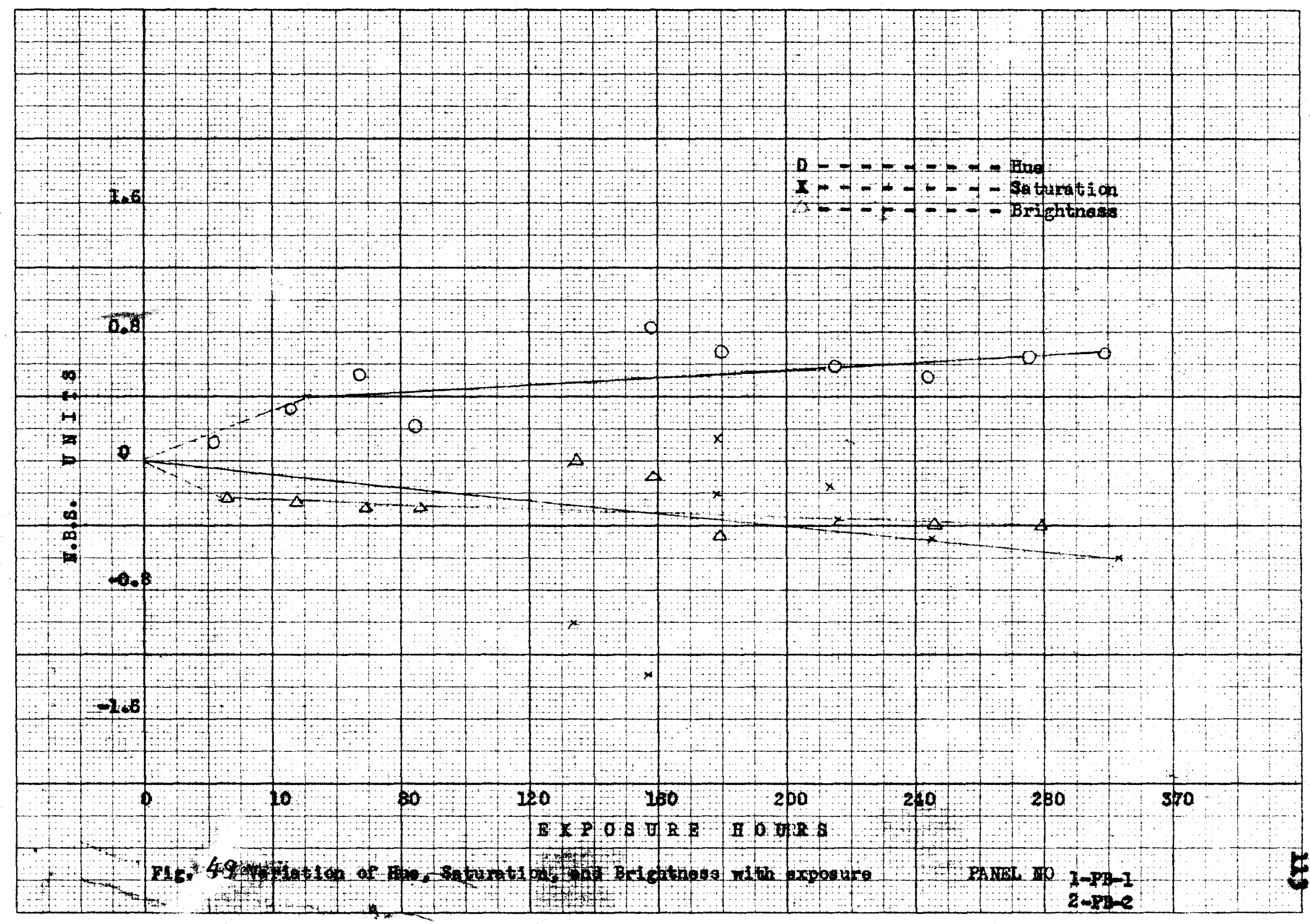




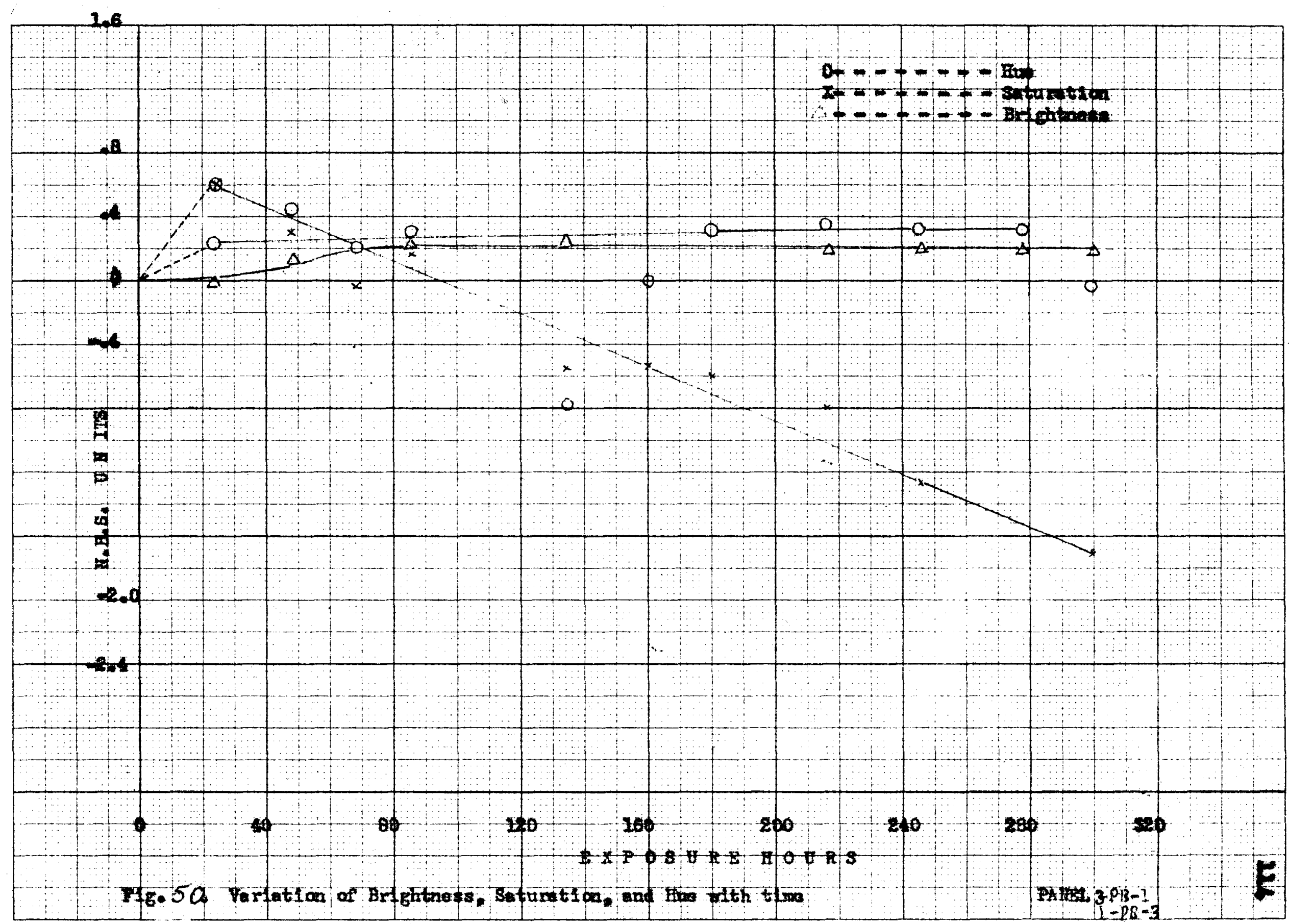


CONCLUSIONS 
The results show that the following plgments and plement mixtures have the oapaeity to withstand the action of ultre violet light for 300 hours wh thout changing undesirably. In other words the fading takes place in such a manner as to produce a flnal color whloh elther did not differ Irom the orlginal or it ohanged for the better, produclng a color of higher saturation then the original. A list of these plgments is as follows:

1. Brtra light toluidine

2. Dark toluldino

3. D.D.D. tolndalne

4. Mixture of cark tolulaine and D.D.D. toluidine in the ratio of $2: 1$

5. Milor1 blue 40222 T1 pux R-610

6. Medium orange

7. Dark Orange

8. Extra dark orango

It is reasonable to conolude that the pignents given in the above liat are mainly responsible for the ohareoterlat10 fading shown by the coatinge. The rehlele and the resing did not have any notloeable effoet. Driers may have nome orfeot on the plementa but it has got to be determined. The rest of the pionent and pigment mixtures tried, need a ohange in thelr composition or noed some additives whioh would prevent undesirable.fading. 
TABLE I HOWTER KETLECTOMETER READINGS WITH SAMPLE CALCULATIONS

$$
\text { PAMEL 27: } \begin{array}{r}
1-P B-1 \\
3-P B-2
\end{array}
$$

Maoblne Readings

\begin{tabular}{|c|c|c|c|c|c|c|c|c|c|}
\hline $\begin{array}{r}\text { Hr: } \\
0\end{array}$ & $0.3250^{\circ}$ & $0.1740^{A}$ & $\begin{array}{c}0 \\
0.1820\end{array}$ & 0.0136 & 0.0349 & 0.2654 & $\begin{array}{l}A+20+B \\
-0.0213\end{array}$ & $\begin{array}{c}A-0 \\
-0.0588\end{array}$ & $\begin{array}{r}0.4(0-B) \\
-0.0588\end{array}$ \\
\hline 23 & 0.3190 & 0.1730 & 0.2090 & 0.1785 & 0.0235 & 0.0342 & 0.2604 & -0.0207 & -0.0577 \\
\hline 47 & 0.3175 & 0.1734 & 0.4074 & 0.1777 & 0.0136 & 0.0340 & 0.2592 & -0.2592 & -0.0205 \\
\hline 67 & 0.3170 & 0.1740 & 0.4060 & 0.2774 & 0.0136 & 0.0339 & 0.2588 & -0.0203 & -0.0574 \\
\hline 85 & 0.3240 & 0.1745 & 0.4065 & 0.1757 & 0.0142 & 0.0339 & 0.2571 & -0.0203 & -0.0567 \\
\hline 133 & 0.3170 & 0.1800 & 0.4170 & 0.1774 & 0.0147 & 0.0349 & 0.2614 & -0.1207 & -0.0570 \\
\hline 159 & 0.3170 & 0.1855 & 0.4143 & 0.1774 & 0.0133 & 0.0346 & 0.2613 & -0.0199 & -0.0572 \\
\hline 180 & 0.3240 & 0.1765 & 0.3990 & 0.1757 & 0.0135 & 0.0333 & 0.2556 & -0.0200 & -0.0570 \\
\hline 216 & 0.3130 & 0.1726 & 0.4020 & 0.1752 & 0.0137 & 0.0335 & 0.2557 & -0.0200 & -0.0567 \\
\hline 245 & 0.3120 & 0.1754 & 0.4023 & 0.1746 & 0.0137 & 0.0336 & 0.2555 & -0.0199 & -0.0564 \\
\hline 277 & 0.3103 & 0.1745 & 0.3990 & 0.1736 & 0.0136 & 0.0333 & 0.2538 & -0.0197 & -0.0561 \\
\hline 300 & 0.3090 & 0.1760 & 0.4010 & 0.1728 & 0.0136 & 0.0334 & 0.2534 & -0.0191 & -0.0558 \\
\hline
\end{tabular}


TABLX I (COnt'd) HUNTER REFLECTOMETER READTHCS WITH SAMPLF CALCULATIONS PANEL 27: $\frac{1-P B-1}{3-P B-2}$

\begin{tabular}{|c|c|c|c|c|c|c|c|c|c|}
\hline Hre. & $\alpha$ & $\beta$ & $\alpha^{2}$ & $\beta^{2}$ & $x^{\frac{1}{2}}$ & $\begin{array}{l}X=100 \\
\Delta L \cdot . \\
K \cdot \Delta X^{\frac{1}{2}}\end{array}$ & $\mathbf{y}^{\frac{1}{4}}$ & $\operatorname{AVI}^{\frac{1}{4}}$ & $\sqrt{\alpha^{2}+\beta^{2}}$. \\
\hline 0 & -0.0803 & -0.2216 & 0.0064 & 0.0491 & 0.1868 & $-\infty-\infty$ & 0.4322 & $---\infty$ & 0.2356 \\
\hline 23 & -0.0795 & -0.2216 & 0.0063 & 0.0491 & 0.0049 & -0.19 & 0.4300 & 0.4311 & 0.2354 \\
\hline 47 & -0.0791 & -0.2218 & 0.0063 & 0.0492 & 0.0044 & -0.24 & 0.4294 & 0.4308 & 0.2356 \\
\hline 67 & -0.0784 & -0.2218 & 0.0061 & 0.0492 & 0.0241 & -0.27 & 0.4291 & 0.4307 & 0.2352 \\
\hline 85 & -0.0790 & -0.2205 & 0.0062 & 0.0486 & 0.0041 & -0.23 & 0.4291 & 0.4307 & 0.2341 \\
\hline 133 & -0.0792 & -0.2281 & 0.0063 & 0.0476 & 0.0068 & -0.00 & 0.4322 & 0.4322 & 0.2322 \\
\hline 159 & -0.0762 & -0.2285 & 0.0058 & 0.0477 & 0.1860 & -0.08 & 0.4313 & 0.4318 & 0.2313 \\
\hline 180 & -0.0782 & -0.2230 & 0.0061 & 0.0497 & 0.1825 & -0.43 & 0.4272 & 0.4297 & 0.2362 \\
\hline 216 & -0.0782 & -0.2217 & 0.0061 & 0.0490 & 0.1830 & -0.38 & 0.4278 & 0.4300 & 0.2352 \\
\hline 245 & -0.0779 & -0.2207 & 0.0061 & 0.0487 & 0.1833 & -0.35 & 0.4281 & 0.4302 & 0.2341 \\
\hline 277 & -0.0776 & -0.2210 & 0.0060 & 0.0488 & 0.2825 & -0.43 & 0.4272 & 0.4297 & 0.2341 \\
\hline 300 & -0.0773 & -0.2202 & 0.0060 & 0.0485 & 0.1828 & -0.40 & 0.4276 & 0.4299 & 0.2335 \\
\hline
\end{tabular}


TABLE I (Cont *a) HUNTER RETLECTOUETER RFADTHES WITH SAMPLE CALCULATIONS

\section{PANEL 27: $\begin{aligned} & 1-P B-1 \\ & 3-P B-2\end{aligned}$}

\begin{tabular}{|c|c|c|c|c|c|c|c|c|c|c|}
\hline Hrs. & $\stackrel{2}{A v \cdot \sqrt{\alpha^{2}+\beta^{2}}}$ & $\sqrt[3]{\Delta \sqrt{\alpha^{2}+\beta^{2}}}$ & $\stackrel{4}{700}(1)$ & $\begin{array}{l}\Delta s \\
(3)(4)\end{array}$ & $\frac{\beta}{\alpha}$ & $\operatorname{arc} \tan \frac{\beta}{\alpha}$ & ${ }_{\Delta \phi}^{5}$ & $12.2(1)$ & $(6)(2)$ & $\begin{array}{c}\Delta \mathrm{E}^{\circ} \\
(7)(5)\end{array}$ \\
\hline 0 & 0.2355 & -- & $-\infty$ & $-m$ & 2.7594 & 250.0814 & - & -- & - & - \\
\hline 23 & 0.2356 & -0.0002 & 301.8 & -0.0604 & 2.7748 & 250.1814 & 0.1000 & 5.259 & 1.238 & 0.1238 \\
\hline 47 & 0.2354 & 0.0 & 301.6 & 0.0 & .2 .8040 & 250.3720 & 0.2906 & 5.256 & 1.238 & 0.3598 \\
\hline 67 & 0.2349 & -0.0004 & 301.5 & -0.1206 & 2.8291 & 250.5333 & 0.4519 & 5.255 & 1.237 & 0.5590 \\
\hline 85 & 0.2339 & -0.0025 & 301.5 & -0.4523 & 2.7911 & 250.2883 & 0.2069 & 5.255 & 1.234 & 0.2553 \\
\hline 133 & 0.2335 & -0.0034 & 302.5 & -1.029 & 2.7534 & 250.0394 & -0.0420 & 5.273 & 1.233 & -0.0518 \\
\hline 59 & 0.2349 & -0.0043 & 302.4 & -1.3 & 2.8702 & 250.7908 & 0.7094 & 5.268 & 1.230 & 0.8726 \\
\hline 180 & 0.2354 & -0.0006 & 300.8 & 0.1805 & 2.8515 & 250.6758 & 0.5944 & 5.242 & 1.237 & 0.7353 \\
\hline 20 & 0.2349 & -0.0004 & 301.0 & -0.1204 & 2.8389 & 250.5950 & 0.5136 & 5.246 & 1.235 & 0.6343 \\
\hline 42 & 0.2349 & -0.0015 & 301.1 & -0.4517 & 2.8331 & 250.5583 & 0.4769 & 5.248 & 1.233 & 0.5880 \\
\hline & 0.2346 & -0.0015 & 300.8 & -0.4512 & 2.8479 & 250.6519 & 0.5705 & 5.242 & 1.231 & 0.7023 \\
\hline & - & $-0,0021$ & 300.9 & -0.6319 & 2.8486 & 250.6564 & 0.5750 & 5.245 & 1.230 & 0.7073 \\
\hline
\end{tabular}




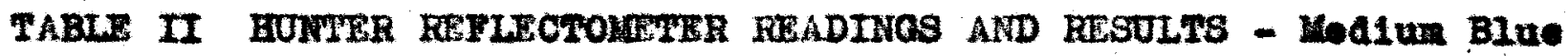
PAMEL No $21-\mathbf{M B}-2$

MACHTIE RFADINOS

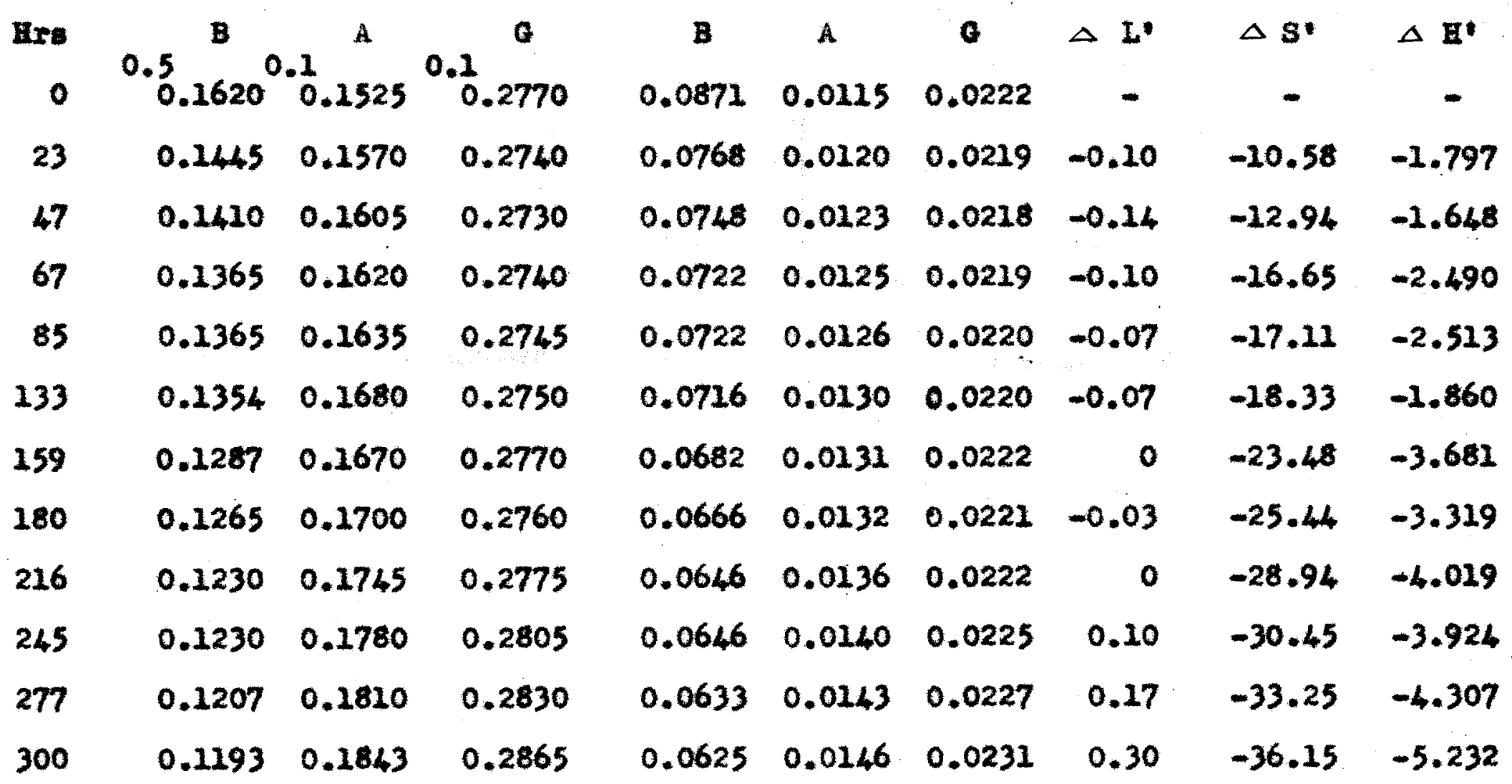


TABLE III HUWTER RWTLBCTOMATER READIMOS AND RESULTS - Medium Blue PAMEL NO $23-\frac{1-\mathrm{MB}-1}{1-\mathrm{MB}-2}$

MACHINE READTHG.

CORRECTED READINGS CALCULATED I.C.I. VALUES

\begin{tabular}{|c|c|c|c|c|c|c|c|c|c|}
\hline $\begin{array}{c}\text { Hre. } \\
0\end{array}$ & $\begin{array}{c}\text { L } \\
0.1570^{\circ}\end{array}$ & $\begin{array}{c}A \\
0.2605\end{array}$ & $\begin{array}{c}.1 \\
0.5140\end{array}$ & $\begin{array}{c}\text { B } \\
0.1561\end{array}$ & 0.0219 & 0.0438 & $\begin{array}{c}\Delta L \\
-\end{array}$ & $\begin{array}{c}\Delta s \\
-\end{array}$ & $\begin{array}{r}\Delta H^{\prime} \\
-\end{array}$ \\
\hline 23 & 0.1485 & 0.2720 & 0.5180 & 0.1476 & 0.0230 & 0.0441 & 0.07 & -0.5770 & .0662 \\
\hline 47 & 0.2435 & 0.2790 & 0.5230 & 0.1428 & 0.0236 & 0.0446 & 0.19 & -4.334 & -1.272 \\
\hline 67 & 0.1403 & 0.2808 & 0.5195 & 0.1397 & 0.0238 & 0.0443 & 0,12 & -5.164 & -2.252 \\
\hline 85 & 0.1377 & 0.2850 & 0.5210 & 0.2371 & 0.0242 & 0.0444 & 0.14 & -6.192 & -2.595 \\
\hline 133 & 0.1330 & 0.2970 & 0.5325 & 0.1325 & 0.0254 & 0.0455 & 0.40 & -8.592 & -3.935 \\
\hline 159 & 0.1325 & 0.3005 & 0.5348 & 0.1320 & 0.0257 & 0.0457 & 0.45 & -8.993 & -4.003 \\
\hline 180 & 0.1290 & 0.3040 & 0.5330 & 0.1285 & 0.0261 & 0.0455 & 0.40 & -10.093 & 4.139 \\
\hline 216 & 0.1265 & 0.3124 & 0,6400 & 0.1260 & 0.0267 & 0.0462 & 0.56 & $-21 \cdot 420$ & -5.210 \\
\hline 245 & 0.1245 & 0.3170 & 0.5400 & 0.1240 & 0.0273 & 0.0462 & 0.56 & $-12 \cdot 468$ & -5.027 \\
\hline 277 & 0.1213 & 0.3250 & 0.5460 & 0.1208 & 0.0281 & 0.0467 & 0.58 & -14.077 & -5.770 \\
\hline 300 & 0.1223 & 0.3150 & 0.5560 & 0.1218 & 0.0281 & 0.0476 & 0.89 & -12.89 & -6.337 \\
\hline
\end{tabular}


TABLE IV HOWTER RETLRCTOMETER READINGS AND RESULTS - Modiun BIU PAREI NO. $24-\frac{3-118-1}{1-18-2}$

MACHIME RRADTMGS

\begin{tabular}{|c|c|c|c|c|c|c|c|c|c|}
\hline $\begin{array}{c}\text { Hrs. } \\
0\end{array}$ & $L_{0.1850^{\circ}}$ & $\begin{array}{c}A \\
0.3110\end{array}$ & $\begin{array}{c}0 \\
0.1000\end{array}$ & $\begin{array}{c}B \\
0.1837\end{array}$ & $\begin{array}{c}A \\
0.0267\end{array}$ & 0.0512 & $\begin{array}{c}\Delta L \\
-\end{array}$ & $\begin{array}{c}\Delta \mathbf{s}^{\prime} \\
-\end{array}$ & $\begin{array}{c}\Delta \mathbf{H}^{*} \\
-\end{array}$ \\
\hline 23 & 0.1743 & 0.3280 & 0.1015 & 0.1733 & 0.0284 & 0.0520 & 0.17 & -3.303 & -1.212 \\
\hline 47 & 0.1725 & 0.3223 & 0.1022 & 0.1714 & 0.0278 & 0.0524 & 0.26 & -3.474 & -2.053 \\
\hline 67 & 0.1655 & 0.3353 & 0.1015 & 0.1645 & 0.0291 & 0.0520 & 0.17 & -4.537 & $-4 \cdot 347$ \\
\hline 85. & 0.1645 & 0.3390 & 0.1023 & 0.1635 & 0.0294 & 0.0524 & 0.26 & -6.212 & 2.686 \\
\hline 133 & 0.1600 & 0.3465 & 0.1030 & 0.1591 & 0.0302 & 0.0528 & 0.35 & -7.722 & -3.251 \\
\hline 159 & 0.1580 & 0.3530 & 0.1035 & 0.1571 & 0.0308 & 0.0531 & 0.41 & -8.764 & -3.425 \\
\hline 180 & 0.1540 & 0.3528 & 0.1035 & 0.1531 & 0.0308 & 0.0531 & 0.41 & -9.600 & -4.357 \\
\hline 216 & 0.1440 & 0.3640 & 0.1040 & 0.1482 & 0.0318 & 0.0534 & 0.48 & -11.447 & -4.821 \\
\hline 245 & 0.1490 & 0.3775 & 0.1060 & 0.1482 & 0.0331 & 0.0545 & 0.72 & -12.689 & -4.800 \\
\hline 277 & 0.1447 & 0.3865 & 0.1065 & 0.1440 & 0.0341 & 0.0548 & 0.78 & -14.446 & -5.133 \\
\hline 300 & 0.1445 & 0.4000 & 0.2083 & 0.1438 & 0.0353 & 0.0558 & 0.99 & -15.517 & -5.179 \\
\hline
\end{tabular}




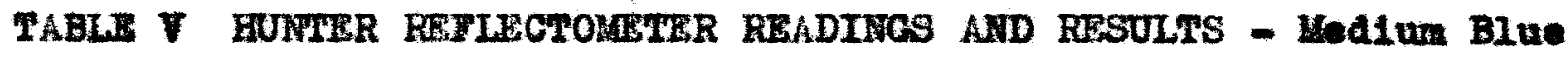

PANEL HO. $22-\frac{1-3 B-1}{3-1 B B-2}$

MACHINE READINC8

COREECTED RRADTHOS CALCULATED I.C.I. VALUES

\begin{tabular}{|c|c|c|c|c|c|c|c|c|c|}
\hline $\begin{array}{c}\text { Hrs. } \\
0\end{array}$ & $L_{0.1290^{\circ}}$ & $\begin{array}{cc}A \\
0.2021\end{array}$ & $\begin{array}{cc}0 \\
0.2 \\
0.3020\end{array}$ & $\begin{array}{c}B \\
0.1285\end{array}$ & $\begin{array}{c}A \\
0.0161\end{array}$ & $\begin{array}{c}6 \\
0.0326\end{array}$ & $\begin{array}{r}\Delta L^{\prime} \\
-\end{array}$ & $\begin{array}{c}\Delta B^{\prime} \\
-\end{array}$ & $\begin{array}{c}\Delta H^{*} \\
-\end{array}$ \\
\hline 23 & 0.1190 & 0.2125 & 0.3965 & 0.1185 & 0.0172 & 0.0330 & 0.11 & -3.40 & -2.047 \\
\hline 47 & 0.1150 & 0.2100 & 0.3950 & 0.1144 & 0.0176 & 0.0328 & 0.05 & 4.317 & -2.161 \\
\hline 67 & 0.1065 & 0.2095 & 0.3930 & 0.1058 & 0.0179 & 0.0327 & 0.02 & 7.083 & -3.981 \\
\hline 85 & 0.1070 & 0.2220 & 0.3960 & 0.1063 & 0.0181 & 0.0330 & 0.11 & 7.271 & -4.067 \\
\hline 133 & 0.1060 & 0.2270 & 0.3955 & 0.1053 & 0.0186 & 0.0329 & 0.08 & 7.865 & -3.526 \\
\hline 159 & 0.1054 & 0.2275 & 0.3990 & 0.1047 & 0.0187 & 0.0333 & 0.19 & 8.320 & -4.967 \\
\hline 180 & 0.1030 & 0.2315 & 0.3975 & 0.1021 & 0.0191 & 0.0331 & 0.13 & 9.480 & -3.516 \\
\hline 216 & 0.1010 & 0.2375 & 0.4000 & 0.1000 & 0.0190 & 0.0333 & 0.19 & 20.676 & -4.135 \\
\hline 245 & 0.1000 & 0.2450 & 0.4070 & 0.0990 & 0.0240 & 0.0340 & 0.38 & 12.110 & -4.515 \\
\hline 277 & 0.0990 & 0.2515 & 0.4120 & 0.0980 & 0.0210 & 0.0344 & 0.49 & 13.178 & -4.652 \\
\hline 300 & 0.0980 & 0.2585 & 0.4210 & 0.0970 & 0.0217 & 0.0352 & 0.70 & 14.419 & -5.374 \\
\hline
\end{tabular}


TABLS II HUNTAR REPLFCTOMETER READIMOS AMD RESULTS - Peaceok Blue PAMEL NO. 30 - PB-1

\section{MACHII READIMES}

\begin{tabular}{|c|c|c|c|c|c|c|c|c|c|}
\hline $\begin{array}{r}\text { Hre } \\
0\end{array}$ & $L_{0.2805}^{B}$ & $\begin{array}{cc}A \\
.1 & \\
0.2741\end{array}$ & $\begin{array}{c}0.5 \\
0.1100\end{array}$ & 0.2802 & 0.0232 & 0.0567 & $\begin{array}{r}\Delta L^{\prime} \\
-\end{array}$ & $\begin{array}{c}\Delta \mathbf{s}^{*} \\
-\end{array}$ & $\begin{array}{c}\Delta H^{*} \\
-\end{array}$ \\
\hline 23 & 0.2865 & 0.2770 & 0.1115 & 0.2862 & 0.0235 & 0.0575 & .17 & 0.2394 & 0.2031 \\
\hline 47 & 0.2850 & 0.2770 & 0.1105 & 0.2847 & 0.0235 & 0.0569 & 0.04 & 0.3076 & 0.5684 \\
\hline 67 & 0.2860 & 0.2800 & 0.1110 & 0.2878 & 0.0239 & 0.0573 & 0.13 & 0.3763 & 0.6054 \\
\hline 85 & 0.2885 & 0.2799 & 0.2113 & 0.2883 & 0.0237 & 0.0574 & 0.15 & 0.4488 & 0.6862 \\
\hline 133 & 0.2876 & 0.2835 & 0.1150 & 0.2874 & 0.0241 & 0.0593 & 0.54 & -0.6528 & -0.7540 \\
\hline 159 & 0.2860 & 0.2844 & 0.1114 & 0.2857 & 0.0242 & 0.0573 & 0.13 & 0 & 0.8640 \\
\hline 180 & 0.2840 & 0.2850 & 0.1215 & 0.2837 & 0.0242 & 0.0575 & 0.17 & -0.3765 & 0.4864 \\
\hline 216 & 0.2845 & 0.2930 & 0.1120 & 0.2842 & 0.0250 & 0.0577 & 0.21 & -0.8218 & 0.9610 \\
\hline 245 & 0.2845 & 0.2930 & 0.1120 & 0.2842 & 0.0250 & 0.0577 & 0.21 & -0.8218 & 0.9610 \\
\hline 277 & 0.2830 & 0.2925 & 0.1123 & 0.2827 & 0.0249 & 0.0579 & 0.25 & -0.9590 & 0.5398 \\
\hline 300 & 0.2825 & 0.2930 & 0.2130 & 0.2822 & 0.0250 & 0.0582 & 0.31 & -1.268 & 0.2810 \\
\hline
\end{tabular}




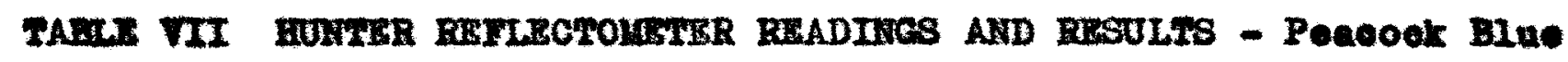
PAVIR NO. 26 - PB-2

\section{MACHTIE RBADTNOS}

\begin{tabular}{|c|c|c|c|c|c|c|c|c|c|}
\hline $\begin{array}{c}\text { Erw. } \\
0\end{array}$ & $0.5{ }_{0.2280^{0}}^{0}$ & $\begin{array}{c}1 \\
.1 \\
0.1295\end{array}$ & $\begin{array}{c}0.1 \\
0.2840\end{array}$ & 0.1253 & 0.0093 & $\begin{array}{c}0 \\
0.0228\end{array}$ & $\begin{array}{r}\Delta L^{\prime} \\
-\end{array}$ & $\begin{array}{c}\Delta g^{*} \\
-\end{array}$ & $\begin{array}{c}\Delta H^{*} \\
-\end{array}$ \\
\hline 23 & 0.2260 & 0.1285 & 0.2790 & 0.1241 & 0.0092 & 0.0224 & -0.23 & 0.8415 & -0.1734 \\
\hline 47 & 0.2065 & 0.1290 & 0.2780 & 0.1129 & 0.0093 & 0.0223 & -0.17 & -2.4140 & -1.6960 \\
\hline 67 & 0.2267 & 0.1300 & 0.2890 & 0.1245 & 0.0093 & 0.0224 & -0.13 & 0.1086 & 0.4676 \\
\hline 85 & 0.2235 & 0.1290 & 0.2770 & 0.1227 & 0.0093 & 0.0222 & -0.20 & -0.1084 & 0.5136 \\
\hline 133 & 0.2270 & 0.1325 & 0.2880 & 0.1249 & 0.0096 & 0.0223 & -0.17 & 0.0543 & 1.1450 \\
\hline 159 & 0.2250 & 0.1255 & 0.2805 & 0.1236 & 0.0099 & 0.0224 & -0.13 & -0.5158 & 1.2070 \\
\hline 160 & 0.2255 & 0.1353 & 0.2825 & 0.1238 & 0.0098 & 0.0227 & -0.03 & -0.7341 & 0.5723 \\
\hline 216 & 0.2245 & 0.1367 & 0.2845 & 0.1233 & 0.0100 & 0.0229 & 0.03 & -0.9202 & 0.4965 \\
\hline 245 & 0.2244 & 0.1390 & 0.2860 & 0.1232 & 0.0102 & 0.0230 & 0.07 & -1.3350 & 0.5990 \\
\hline 277 & 0.2230 & 0.1387 & 0.2830 & 0.1224 & 0.0102 & 0.0227 & -0.03 & -1.1420 & 0.9820 \\
\hline 300 & 0.2230 & 0.1393 & 0.2850 & 0.1224 & 0.0102 & 0.0229 & 0.03 & -1.4420 & 0.5879 \\
\hline
\end{tabular}


TABLD VIII HUNTER REPLECROMETER READIWGS AND FESULTS - Pea000k BIUe

$$
\text { PARSL HO. } 29-\underset{1-P B-2}{3-P B-1}
$$

MACHINE ERADTHGS

CORRECTED READTHES

B

$\begin{array}{lll}0.2564 & 0.0207 & 0.0512\end{array}$

Hrs.

$L_{0.2570^{0.2}}{ }_{0.2485}^{\mathrm{A}} \mathrm{L}_{0.1000}^{0.5}$

$23 \quad 0.2595 \quad 0.2430 \quad 0.0983$

$\begin{array}{llll}47 & 0.2643 & 0.2517 & 0.1013\end{array}$

$\begin{array}{llll}67 & 0.2635 & 0.2534 & 0.2020\end{array}$

$850.2650 \quad 0.2540 \quad 0.1020$

$\begin{array}{llll}133 & 0.2630 & 0.2620 & 0.1023\end{array}$

$\begin{array}{llll}159 & 0.2630 & 0.2590 & 0.1030\end{array}$

$\begin{array}{llll}180 & 0.2615 & 0.2608 & 0.1024\end{array}$

216

245

277

300 $\begin{array}{lll}0.2625 & 0.2650 & 0.1030\end{array}$

$\begin{array}{lll}0.2605 & 0.2670 & 0.1030\end{array}$

$\begin{array}{lll}0.2603 & 0.2675 & 0.1030\end{array}$

$\begin{array}{lll}0.2605 & 0.2690 & 0.1040\end{array}$ $\begin{array}{lll}0.2589 & 0.0202 & 0.0508\end{array}$

$\begin{array}{lll}0.2637 & 0.0210 & 0.0519\end{array}$

$\begin{array}{lll}0.2629 & 0.0213 & 0.0523\end{array}$

0.26440 .02120 .0523

$\begin{array}{lll}0.2624 & 0.0222 & 0.0525\end{array}$

$\begin{array}{lll}0.2624 & 0.0217 & 0.0528\end{array}$

$\begin{array}{lll}0.2609 & 0.0219 & 0.0525\end{array}$

$\begin{array}{lll}0.2619 & 0.0223 & 0.0528\end{array}$

$\begin{array}{lll}0.2599 & 0.0225 & 0.0528\end{array}$

$\begin{array}{lll}0.2597 & 0.0227 & 0.0528\end{array}$

$\begin{array}{lll}0.2597 & 0.0227 & 0.0534\end{array}$
CALCULATED I.C.I. VALUHS

$\Delta$ L. $^{\prime} \Delta \mathrm{S}^{\prime} \quad \Delta \mathrm{H}^{\prime}$

$\begin{array}{lll}-0.09 & 0.6321 & 0.2545\end{array}$

$\begin{array}{lll}0.15 & 0.3336 & 0.4768\end{array}$

$\begin{array}{lll}0.24 & 0 & 0.2312\end{array}$

$\begin{array}{lll}0.24 & 0.2003 & 0.3348\end{array}$

$\begin{array}{lll}0.28 & -0.5344 & -0.7515\end{array}$

$\begin{array}{lll}0.24 & -0.5342 & 0.0368\end{array}$

$\begin{array}{lll}0.28 & -0.6012 & 0.3307\end{array}$

$\begin{array}{lll}0.24 & -0.8014 & 0.3877\end{array}$

$\begin{array}{lll}0.24 & -1.235 & 0.3861\end{array}$

$\begin{array}{lll}0.24 & -3.106 & 0.3681\end{array}$

$\begin{array}{lll}0.48 & -3.414 & -0.0095\end{array}$ 
TABLE IX HUNTER RETLECTOMETER READINGS AND RESULTS - Green

PAMEL Ho. 20 - G-1

MACHITE READIMOS

\begin{tabular}{|c|c|c|c|c|c|c|c|c|c|}
\hline \multirow[b]{2}{*}{$\begin{array}{r}\text { Brs } \\
0\end{array}$} & \multicolumn{3}{|c|}{ MACHITE FEADINOS } & \multicolumn{3}{|c|}{ CORRECTED READINCS } & \multicolumn{3}{|c|}{ CALCULATED I.C.I. VALUSE } \\
\hline & ${ }_{0.2}{ }_{0.3750}^{B}$ & $\begin{array}{c}A \\
0.5350\end{array}$ & $\begin{array}{c}0 \\
0.5 \\
0.1405\end{array}$ & $\begin{array}{c}B \\
0.0283\end{array}$ & 0.0483 & 0.0773 & $\begin{array}{r}\Delta I^{\prime} \\
-\end{array}$ & $\begin{array}{r}\Delta \mathbf{s}^{\prime} \\
-\end{array}$ & $\begin{array}{c}\Delta \mathbf{H}^{*} \\
-\end{array}$ \\
\hline 23 & 0.3920 & 0.5470 & 0.1465 & 0.0296 & 0.0495 & 0.0768 & -0.09 & -3.2351 & -0.5914 \\
\hline 47 & 0.3945 & 0.5525 & 0.0063 & 0.0298 & 0.0500 & 0.0767 & -0.11 & -4.1670 & -0.5914 \\
\hline 67 & 0.3943 & 0.5525 & 0.0066 & 0.0298 & 0.0500 & 0.0769 & -0.07 & -3.9103 & -0.8251 \\
\hline 85 & 0.3930 & 0.5580 & 0.0067 & 0.0297 & 0.0505 & 0.0770 & -0.05 & -4.5752 & -1.327 \\
\hline 133 & 0.3965 & 0.5705 & 0.0065 & 0.0300 & 0.0517 & 0.0768 & 0.09 & -6.7490 & -2.397 \\
\hline 159 & 0.3930 & 0.5707 & 0.0065 & 0.0297 & 0.0518 & 0.0768 & -0.09 & -6.796 & -2.846 \\
\hline 180 & 0.3890 & 0.5700 & 0.0053 & 0.0294 & 0.0517 & 0.0762 & -0.20 & -7.1485 & -3.000 \\
\hline 216 & 0.3910 & 0.5820 & 0.0054 & 0.0295 & 0.0528 & 0.0762 & -0.20 & -8.6961 & -4.002 \\
\hline 245 & 0.3910 & 0.5890 & 0.0065 & 0.0295 & 0.0535 & 0.0768 & -0.09 & -9.2945 & -4.168 \\
\hline 277 & 0.3850 & 0.6000 & 0.0065 & 0.0290 & 0.0536 & 0.0767 & -0.11 & -9.4613 & -4.921 \\
\hline 300 & 0.3890 & 0.6045 & 0.0053 & 0.0294 & 0.0550 & 0.0762 & -0.20 & -11.8282 & -6.374 \\
\hline
\end{tabular}

\begin{abstract}
CALCULATED I.C.I. VALUES
\end{abstract}
CORRECTED READINGS 
TABLS X HUMTER BETLECTOMETER READINGS AND RBSULTS - Green

PANEL NO. $19-0-2$

NACHINE READINCS

CORRECTED RRADIMAS CALCULATED I.C.I. VALUES

\begin{tabular}{|c|c|c|c|c|c|c|c|c|c|}
\hline $\begin{array}{c}\text { Hra. } \\
0\end{array}$ & $0.1_{0.3620^{\circ}}^{0}$ & $\begin{array}{c}1 \\
0.3965\end{array}$ & $\begin{array}{c}0 \\
0.5 \\
0.1140\end{array}$ & $\begin{array}{c}B \\
0.0271\end{array}$ & $\begin{array}{c}A \\
0.0349\end{array}$ & $\begin{array}{c}0 \\
0.0587\end{array}$ & $\begin{array}{c}\Delta, L \\
-\end{array}$ & $\Delta \mathbf{s}^{\circ}$ & $\begin{array}{c}\Delta \mathrm{H}^{*} \\
-\end{array}$ \\
\hline 23 & 0.3740 & 0.4010 & 0.1155 & 0.0281 & 0.0354 & 0.0595 & 0.16 & -0.2416 & 0.2710 \\
\hline 47 & 0.3750 & 0.4010 & 0.1150 & 0.0282 & 0.0354 & 0.0593 & 0.12 & 0.8301 & 0.3981 \\
\hline 67 & 0.3740 & 0.4010 & 0.1144 & 0.0281 & 0.0354 & 0.0589 & 0.04 & 1.4213 & 0.3852 \\
\hline 85 & 0.3740 & 0.4050 & 0.1150 & 0.0282 & 0.0357 & 0.0593 & 0.12 & 1.277 & -0.0160 \\
\hline 133 & 0.3450 & 0.4130 & 0.1143 & 0.0382 & 0.0365 & 0.0589 & 0.14 & 3.447 & -0.7846 \\
\hline 159 & 0.3750 & 0.4150 & 0.1150 & 0.0285 & 0.0367 & 0.0593 & 0.12 & 3. 209 & -0.7684 \\
\hline 180 & 0.3660 & 0.4140 & 0.1135 & 0.0275 & 0.0366 & 0.0585 & 0.04 & 3.823 & -1.489 \\
\hline 216 & 0.3690 & 0.4235 & 0.1135 & 0.0278 & 0.0375 & 0.0585 & -0.04 & 5.579 & -2.093 \\
\hline 245 & 0.3700 & 0.4270 & 0.1130 & 0.0278 & 0.0879 & 0.0582 & -0.11 & 6.884 & -2.623 \\
\hline 277 & 0.3607 & 0.4320 & 0.1140 & 0.0271 & 0.0383 & 0.0587 & 0.00 & -6.512 & -3.215 \\
\hline 300 & 0.3650 & 0.4350 & 0.1135 & 0.0274 & 0.0386 & 0.0585 & -0.04 & -7.542 & -3.401 \\
\hline
\end{tabular}




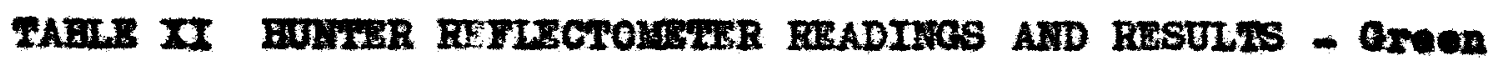

PAMRL No. 16 - a-3

MACHIRE RRADTHES

\begin{tabular}{|c|c|c|c|c|c|c|c|c|c|}
\hline $\begin{array}{c}\text { Ars: } \\
0\end{array}$ & $0.2_{0.3610^{\circ}}^{\mathrm{B}}$ & $\frac{1}{0.2730}$ & $0 . \frac{1}{0.3530}$ & $\begin{array}{c}\text { D } \\
0.0271\end{array}$ & $\begin{array}{c}A \\
0.0135\end{array}$ & 0.0291 & $\begin{array}{r}\Delta I^{*} \\
-\end{array}$ & $\begin{array}{r}\Delta \mathbf{s}^{*} \\
-\end{array}$ & $\begin{array}{r}\Delta \mathbf{E}^{*} \\
-\end{array}$ \\
\hline 23 & 0.3420 & 0.2745 & 0.3460 & 0.0255 & 0.0136 & 0.0285 & -0.18 & -1.673 & -1.276 \\
\hline 47 & 0.3360 & 0.1730 & 0.3430 & 0.0250 & 0.0135 & 0.0252 & -0.27 & -0.7200 & -1.665 \\
\hline 67 & 0.3330 & 0.1730 & 0.3552 & 0.0246 & 0.0235 & 0.0293 & 0.06 & 1.881 & -3.177 \\
\hline 85 & 0.3240 & 0.1730 & 0.3310 & 0.0240 & 0.0135 & 0.0271 & -0.60 & -2.694 & -1.624 \\
\hline 133 & 0.3240 & 0.1750 & 0.3270 & 0.0240 & 0.0137 & 0.0267 & -0.72 & -4.262 & -1.439 \\
\hline & 0.3210 & 0.1750 & 0.3230 & 0.0238 & 0.0137 & 0.0264 & -0.81 & -4.856 & -1.172 \\
\hline & 0.3163 & 0.1740 & 0.3180 & 0.0234 & 0.0137 & & -0.97 & -5.471 & -1.275 \\
\hline & 0.3150 & 0.1785 & 0.3190 & 0.0233 & 0.0136 & .0260 & -0.94 & -6.501 & -1.669 \\
\hline & 0.3100 & 0.1780 & 0.3125 & 0.0230 & 0.0140 & 0.0272 & -0.57 & -3.670 & -3.337 \\
\hline & 0.3035 & 0.1805 & 0.3130 & 0.0223 & 0.0140 & 0.0272 & -0.57 & -3.097 & -4.348 \\
\hline & 0.3075 & 0.1633 & 0.3180 & 0.0227 & 0.0143 & 0.0258 & -1.00 & -7.890 & -2.209 \\
\hline
\end{tabular}


TABLS III HUWTER REYLECTOMETER READIMES AND RESULTS - Green

$$
\text { PAIET } 170.17-\frac{1-\theta-2}{2-a-3}
$$

HACEII READIMOS

\begin{tabular}{|c|c|c|c|c|c|c|c|c|c|}
\hline $\begin{array}{c}\text { Hr: } \\
0\end{array}$ & ${ }_{0.1}{ }_{0.3300}^{B}$ & $\begin{array}{c}1 \\
-1 \\
-0.2900\end{array}$ & 0.10 & $\begin{array}{c}\text { B } \\
0.0245\end{array}$ & $\begin{array}{c}A \\
0.0251\end{array}$ & $\begin{array}{c}0 \\
0.0320\end{array}$ & $\begin{array}{r}\Delta L^{\prime} \\
-\end{array}$ & $\begin{array}{c}\Delta \mathbf{s}^{\prime} \\
-\end{array}$ & $\begin{array}{r}\Delta \mathbf{E}^{\prime} \\
-\end{array}$ \\
\hline 23 & 0.3425 & 0.2045 & 0.4015 & 0.0256 & 0.0165 & 0.0335 & 0.41 & -2.025 & -0.4805 \\
\hline 47 & 0.3410 & 0.2070 & 0.4040 & 0.0254 & 0.0167 & 0.0337 & 0.47 & -2.206 & -0.7430 \\
\hline 67 & 0.3380 & 0.2083 & 0.4010 & 0.0252 & 0.0168 & 0.0334 & 0.39 & -2.947 & -0.9592 \\
\hline 85 & 0.3345 & 0.2090 & 0.4000 & 0.0249 & 0.0169 & 0.0333 & 0.36 & -3.244 & -1.363 \\
\hline 133 & 0.3318 & 0.2225 & 0.3995 & 0.0247 & 0.0172 & 0.0328 & 0.22 & -5.109 & -1.239 \\
\hline 159 & 0.3302 & 0.2140 & 0.3945 & 0.0245 & 0.0273 & 0.0329 & 0.25 & -4.992 & -0.9812 \\
\hline 180 & 0.3273 & 0.2250 & 0.3925 & 0.0243 & 0.0274 & 0.0327 & 0.19 & -5.700 & -2.955 \\
\hline 216 & 0.3283 & 0.2200 & 0.3930 & 0.0244 & 0.0179 & 0.0327 & 0.19 & -7.362 & -1.460 \\
\hline 245 & 0.3270 & 0.2205 & 0.3870 & 0.0243 & 0.0180 & 0.0322 & 0.05 & -8.623 & -1.928 \\
\hline 277 & 0.3210 & 0.2260 & 0.3920 & 0.0238 & 0.0185 & 0.0327 & 0.19 & -9.758 & -2.045 \\
\hline 300 & 0.3255 & 0.2300 & 0.3940 & 0.0242 & 0.0189 & 0.0329 & 0.05 & -9.885 & -3.035 \\
\hline
\end{tabular}

GALCULATED I.O.I. VALUES

COREROTED READIIHSS

$\Delta L^{*} \Delta \mathbf{S}^{*} \Delta \mathrm{E}^{\prime}$ 
TABLE IIII HUNTER RETLETOMETER READLMGS AND RBSULTS - Oroon

$$
\text { PANBL No. } 18-\begin{array}{r}
2-a-2 \\
1-a-3
\end{array}
$$

YACHIRE READINOS

\begin{tabular}{|c|c|c|c|c|c|c|}
\hline $\begin{array}{c}\text { Hrs. } \\
0\end{array}$ & $1_{0.3750^{\circ}}$ & $\begin{array}{cc}1 \\
0.2610\end{array}$ & 0.210 & $\begin{array}{c}\mathbf{B} \\
0.0282\end{array}$ & $\begin{array}{c}A \\
0.0238\end{array}$ & $\begin{array}{c}a \\
0.0481\end{array}$ \\
\hline 22 & 0.3690 & 0.2985 & 0.5520 & 0.0277 & 0.0255 & 0.0472 \\
\hline 47 & 0.3650 & 0.2800 & 0.5390 & 0.0272 & 0.0237 & 0.0461 \\
\hline 67 & 0.3622 & 0.2780 & 0.5335 & 0.0272 & 0.0235 & 0.0456 \\
\hline 85 & 0.3750 & 0.2790 & 0.5290 & 0.0268 & 0.0236 & 0.0452 \\
\hline 133 & 0.3520 & 0.2810 & 0.5170 & 0.0263 & 0.0238 & 0.0441 \\
\hline 159 & 0.3505 & 0.2830 & 0.5170 & 0.0262 & 0.0240 & 0.0441 \\
\hline 180 & 0.3450 & 0.2821 & 0.5105 & 0.0258 & 0.0239 & 0.0435 \\
\hline 216 & 0.3520 & 0.2925 & 0.5170 & 0.0263 & 0.0249 & 0.0441 \\
\hline 245 & 0.3445 & 0.2910 & 0.5090 & 0.0258 & 0.0248 & 0.0434 \\
\hline 277 & 0.3185 & 0.2950 & 0.5090 & 0.0253 & 0.0252 & 0.0434 \\
\hline 300 & 0.3425 & 0.2980 & 0.5110 & 0.0258 & 0.0255 & 0.0435 \\
\hline
\end{tabular}

CALCULATED I.C.I. VALUES

$$
\begin{array}{ccc}
\Delta L & \Delta \mathrm{g}^{\prime} & \Delta \mathrm{H}^{\prime} \\
- & - & - \\
-0.20 & -5.365 & -1.454 \\
-0.46 & -\mathbf{2 . 2 0 3} & -0.3163 \\
-0.58 & -2.801 & -0.2513 \\
-0.67 & -3.383 & -0.6546 \\
-0.93 & -5.513 & -0.9535 \\
-0.93 & -5.935 & -1.355 \\
-1.07 & -6.475 & -1.481 \\
-0.93 & -8.302 & -1.850 \\
-1.10 & -9.063 & -2.113 \\
-2.20 & -9.646 & -3.211 \\
-1.07-10.554 & -2.882
\end{array}
$$


TABLS XIV HUMTER REFLECTOMRTBR READTHES AND HESULTS - YoLlOW

PANRL WO 15 - T-1

MACEINE READINCS

CORRECTED READTHES

CALOULATED I.C.I. VALUES

\begin{tabular}{|c|c|c|c|c|c|c|c|c|c|}
\hline $\begin{array}{c}\text { Hrs. } \\
0\end{array}$ & $0.5 \begin{array}{c}B \\
0.1500\end{array}$ & $\begin{array}{c}1 \\
0.7680\end{array}$ & $\begin{array}{c}G \\
0.7030\end{array}$ & $\begin{array}{c}B \\
0.0802\end{array}$ & $\begin{array}{c}1 \\
0.7682\end{array}$ & $\begin{array}{c}0 \\
0.7040\end{array}$ & $\begin{array}{r}\Delta L^{\prime} \\
-\end{array}$ & $\begin{array}{l}\Delta \mathbf{s}^{\prime} \\
-\end{array}$ & $\begin{array}{r}\Delta \mathbf{H}^{\circ} \\
\quad-\end{array}$ \\
\hline 22 & 0.1420 & 0.7130 & 0.6550 & 0.0754 & 0.7242 & 0.6552 & -2.96 & -0.3278 & 0.2742 \\
\hline 42 & 0.1410 & 0.6910 & 0.6240 & 0.0748 & 0.6918 & 0.6239 & -4.91 & -0.3158 & -3.356 \\
\hline 59 & 0.1400 & 0.6780 & 0.6105 & 0.0744 & 0.6786 & 0.6104 & -5.77 & -0.3150 & -3.985 \\
\hline 85 & 0.1380 & 0.6650 & 0.5990 & 0.0731 & 0.6652 & 0.5988 & -6.52 & 0.3243 & -3.795 \\
\hline 231 & 0.1385 & 0.6450 & 0.5800 & 0.0733 & 0.6450 & 0.5799 & -7.75 & -0.8764 & -4.262 \\
\hline 150 & 0.1380 & 0.6420 & 0.5760 & 0.0731 & 0.6420 & 0.5759 & -8.01 & -0.5630 & -4.600 \\
\hline 200 & 0.1360 & 0.6235 & 0.5570 & 0.0729 & 0.6234 & 0.5570 & -9.27 & -0.5607 & -5.573 \\
\hline 233 & 0.1355 & 0.6080 & 0.5410 & 0.0717 & 0.6079 & 0.5421 & -10.34 & -1.117 & -6.321 \\
\hline 262 & 0.1350 & 0.6440 & 0.5344 & 0.0714 & 0.6028 & 0.5345 & -11.71 & -0.5502 & -7.332 \\
\hline 302 & 0.1345 & 0.5090 & 0.5210 & 0.0711 & 0.5090 & 0.5211 & - & - & - \\
\hline
\end{tabular}


TABL XV HONTER PETLECTOLETER READINGS AD RESULTS - Tellow

PARt No. 13 - Y-2

MACHTHE READTNES

CORRECTED READIHES CALCULATRD I.C.I. VALUES

\begin{tabular}{|c|c|c|c|c|c|c|c|c|c|}
\hline Exs. & $\mathbf{B}$ & $A$ & $a$ & $\mathbf{B}$ & $\boldsymbol{A}$ & a & $\Delta L$ & $\Delta \mathbf{s}^{*}$ & $\Delta \mathbf{E}^{*}$ \\
\hline 0 & $0_{0.3965}^{0.1}$ & ${ }^{L} 0.6835$ & $L_{0.5470}$ & 0.0300 & 0.6842 & 0.5471 & - & - & - \\
\hline 22 & 0.3983 & 0.6225 & 0.5010 & 0.0301 & 0.6224 & 0.5012 & -3.16 & -0.8932 & 1.100 \\
\hline 42 & 0.3975 & 0.6000 & 0.4830 & 0.0301 & 0.5996 & 0.4833 & -4.44 & -1.3040 & 1.131 \\
\hline 59 & 0.3980 & 0.5810 & 0.14665 & 0.0301 & 0.5809 & 0.4672 & -5.61 & -0.6494 & -0.2764 \\
\hline 85 & 0.3935 & 0.5680 & 0.4565 & 0.0297 & 0.5679 & 0.4572 & -6.34 & -0.4122 & 0.8451 \\
\hline 132 & 0.3970 & 0.5650 & 0.4557 & 0.0301 & 0.5649 & 0.4564 & -6.40 & -1.7070 & 1.278 \\
\hline 150 & 0.4053 & 0.5545 & 0.4470 & 0.0307 & 0.5545 & 0.4476 & -7.06 & -1.9380 & 1.223 \\
\hline 200 & 0.4080 & 0.5450 & 0.4390 & 0.0309 & 0.5451 & 0.4394 & -7.67 & -1.934 & 0.8442 \\
\hline 233 & 0.4145 & 0.5260 & 0.4290 & 0.0314 & 0.6261 & 0.4243 & -8.62 & -2.302 & -0.8266 \\
\hline 262 & 0.4020 & 0.5150 & 0.4150 & 0.0304 & 0.5150 & 0.5150 & -9.54 & -2.500 & 0.4468 \\
\hline 302 & 0.4135 & 0.5090 & 0.4060 & 0.0314 & 0.5091 & 0.4057 & -10.27 & -1.277 & -1.538 \\
\hline
\end{tabular}




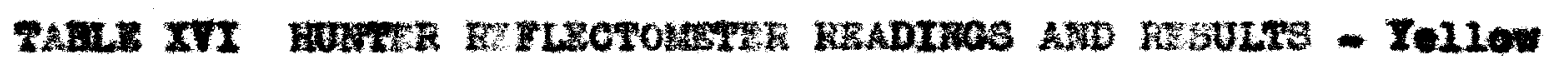
PARBL Wo. $21-7-3$

xachut mantmas

CORRECTRD FEDTHES

CALCULATED I.C.I. TALUES

\begin{tabular}{|c|c|c|c|c|c|c|c|c|c|}
\hline Hre. & $B$ & $\boldsymbol{A}$ & 0 & $\mathbf{B}$ & $\mathbf{A}$ & 0 & $\Delta \mathbf{I}$ & $\Delta \mathbf{g}^{*}$ & $\triangle \mathbf{E}^{*}$ \\
\hline 0 & ${ }^{2} 0.3290$ & $L_{0.6700}$ & ${ }_{0.3185}$ & 0.0244 & 0.6707 & 0.5165 & - & - & - \\
\hline 22 & 0.3400 & 0.6370 & 0.4890 & 0.0253 & 0.6370 & 0.4893 & -2.06 & $-2,003$ & 0.762 \\
\hline 42 & 0.3450 & 0.6280 & 0.4820 & 0.0258 & 0.6200 & 0.4820 & -2.55 & -1.236 & 0.667 \\
\hline 59 & 0.3450 & 0.6270 & 0.4820 & 0.0258 & 0.6270 & 0.4824 & -2.55 & -1.423 & 0.965 \\
\hline 65 & 0.3430 & 0.6250 & 0.4810 & 0.0256 & 0.6250 & 0.4814 & -2.63 & -1.413 & 1.201 \\
\hline 231 & 0.3470 & 0.6220 & 0.4007 & 0.0260 & 0.6218 & 0.4811 & $-2,65$ & -2.060 & 1.946 \\
\hline 150 & 0.3510 & 0.6240 & 0.4024 & 0.0263 & 0.6240 & 0.4830 & -2.51 & -2.061 & 2.044 \\
\hline 200 & 0.3595 & 0.6110 & 0.4730 & 0.0270 & 0.6109 & 0.4736 & -3.19 & -2.643 & 2.333 \\
\hline 233 & 0.3600 & 0.6050 & 0.4765 & 0.0270 & 0.6046 & 0.4772 & -2.94 & -4.215 & 5.468 \\
\hline 262 & 0.3600 & 0.6020 & 0.4650 & 0.0270 & 0.6006 & 0.4657 & -3.77 & -2.462 & 2.2121 \\
\hline 102 & 0.3725 & 0.5990 & 0.4625 & 0.0272 & 0.5987 & 0.4632 & -3.95 & -2.460 & 1.682 \\
\hline
\end{tabular}


TAELE XVII HUNTER REYLECTOUETER READIVTS AND RESULTS - YOL10W

$$
\text { PARE }
$$

MACHTR RBADIMOS

\begin{tabular}{|c|c|c|c|c|c|c|c|c|c|}
\hline $\begin{array}{c}\text { Ers. } \\
0\end{array}$ & $\begin{array}{lc}0.1 & B \\
0.4465\end{array}$ & $\begin{array}{c}\text { L } \\
0.6740\end{array}$ & $I_{0.5540}^{c}$ & $\begin{array}{c}1 \\
0.0381\end{array}$ & $\begin{array}{c}\text { A } \\
0.6745\end{array}$ & $\begin{array}{c}0 \\
0.5589\end{array}$ & $\begin{array}{c}\Delta I^{\circ} \\
-\end{array}$ & $\begin{array}{r}\Delta \boldsymbol{s}^{\prime} \\
-\end{array}$ & $\Delta E^{\prime}$ \\
\hline 22 & 0.4925 & 0.6290 & 0.5230 & 0.0379 & 0.6290 & 0.5231 & -2.43 & -0.7204 & 0.6167 \\
\hline 42 & 0.4970 & 0.6210 & 0.5150 & 0.0383 & 0.6208 & 0.5150 & -3.00 & 0.4790 & 1.095 \\
\hline 59 & 0.4940 & 0.6020 & 0.4490 & 0.0881 & 0.6018 & 0.4992 & -4.21 & -0.4775 & -0.3452 \\
\hline 85 & 0.4884 & 0.5920 & 0.4910 & 0.0377 & 0.5918 & 0.4913 & -4.67 & -0.7148 & 0.3227 \\
\hline 131 & 0.4930 & 0.5740 & 0.4770 & 0.0380 & 0.5738 & 0.4776 & -5.65 & -1.128 & 0.5048 \\
\hline 150 & 0.4990 & 0.5710 & 0.4745 & 0.0385 & 0.5709 & 0.4752 & -5.83 & -1.364 & 0.4463 \\
\hline 200 & 0.5010 & 0.5540 & 0.4590 & 0.0387 & 0.5540 & 0.4597 & -6.96 & -1.359 & -0.2507 \\
\hline 233 & 0.5030 & 0.5500 & 0.4550 & 0.0386 & 0.5501 & 0.4557 & -7.25 & -1.121 & -0.5660 \\
\hline 262 & 0.4950 & 0.5470 & 0.4530 & 0.0382 & 0.5471 & 0.4537 & -7.40 & -2.357 & -0.3609 \\
\hline 302 & 0.5050 & 0.5450 & 0.4510 & 0.0390 & 0.5451 & 0.4517 & -7.55 & -1.592 & -0.5728 \\
\hline
\end{tabular}


TABLS XVIII HUTTER RETLECTOUETER READMNG ATD RESULTS - YO110

$$
\text { PANuL No. } 12-\underset{1-T-2}{1-T}
$$

MACHIIB RBADTNES

\begin{tabular}{|c|c|c|c|c|c|c|c|c|c|}
\hline $\begin{array}{c}\text { Exe. } \\
0\end{array}$ & $\begin{array}{lc}0.1 & B \\
0.0350\end{array}$ & $L_{0.7050}^{A}$ & $\begin{array}{c}0 \\
0.5480\end{array}$ & $\begin{array}{c}\text { B } \\
0.0262\end{array}$ & $\begin{array}{c}1 \\
0.7060\end{array}$ & $\begin{array}{c}6 \\
0.5482\end{array}$ & $\begin{array}{r}\Delta I^{\prime} \\
-\end{array}$ & $\Delta \mathbf{s}^{\prime}$ & $\Delta \mathbf{H}^{\prime}$ \\
\hline 22 & 0.3500 & 0.6430 & 0.5010 & 0.0267 & 0.6431 & 0.5012 & -3.23 & -0.8337 & 0.4622 \\
\hline 42 & 0.3600 & 0.6250 & 0.4880 & 0.0270 & 0.6250 & 0.4883 & -4.15 & -1.481 & 0.8613 \\
\hline 59 & 0.3590 & 0.6140 & 0.4770 & 0.0269 & 0.6138 & 0.4776 & -4.92 & -0.8290 & 0.0890 \\
\hline 85 & 0.3555 & 0.6050 & 0.4770 & 0.0260 & 0.6048 & 0.4776 & -4.92 & -2.546 & 2.781 \\
\hline 31 & 0.3630 & 0.5890 & 0.4600 & 0.0272 & 0.5868 & 0.4607 & -6.16 & -1.886 & 0.9639 \\
\hline .50 & 0.3650 & 0.5650 & 0.4570 & 0.0274 & 0.5884 & 0.4557 & -6.38 & -1.885 & 0.9765 \\
\hline 200 & 0.3690 & 0.5840 & 0.4550 & 0.0277 & 0.5838 & 0.4557 & -6.52 & -1.648 & 0.4385 \\
\hline 233 & 0.3720 & 0.5720 & 0.4460 & 0.0260 & 0.5718 & 0.4466 & -7.20 & -1.879 & 0.4286 \\
\hline 262 & 0.3660 & 0.5662 & 0.4410 & 0.0275 & 0.5661 & 0.4415 & -7.58 & -1. & 0,1920 \\
\hline & 0.3880 & 0.5640 & 0.4400 & 0.0293 & 0.5639 & 0.4405 & -7.67 & -2.111 & 0.3432 \\
\hline
\end{tabular}




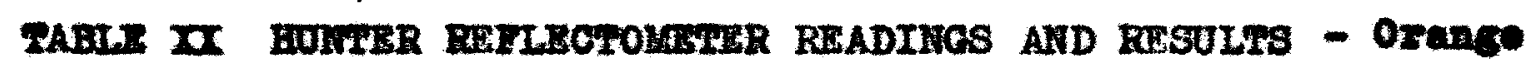

PANEL No. $-0-2$

MACHTIS READTHES

\begin{tabular}{|c|c|c|c|c|c|c|c|c|c|}
\hline $\begin{array}{c}\text { Ere. } \\
0\end{array}$ & $\begin{array}{c}\text { B } \\
0.2970\end{array}$ & $I_{0.3870}^{A}$ & $\begin{array}{c}1 \\
0.2030\end{array}$ & $\begin{array}{c}\text { B } \\
0.0235\end{array}$ & $\begin{array}{c}\text { A } \\
0.3867\end{array}$ & $\begin{array}{c}6 \\
0.2016\end{array}$ & $\begin{array}{c}\Delta L \\
-\end{array}$ & $\begin{array}{c}\Delta \mathbf{g}^{*} \\
-\end{array}$ & $\begin{array}{r}\Delta E^{*} \\
-\end{array}$ \\
\hline 22 & 0.1937 & 0.3840 & 0.2015 & 0.0133 & 0.3837 & 0.2001 & -0.28 & -0.2811 & 0.1401 \\
\hline 42 & 0.1975 & 0.3765 & 0.1685 & 0.0236 & 0.3762 & 0.1172 & -0.50 & -1.029 & 0.4297 \\
\hline 59 & 0.1983 & 0.3790 & 0.2004 & 0.0236 & 0.3787 & 0.1990 & -0.29 & -1.499 & 0.7837 \\
\hline 85 & 0.2010 & 0.3770 & 0.2004 & 0.0139 & 0.3767 & 0.1990 & -0.29 & $-2 \cdot 388$ & $\mathbf{2 . 0 6 6}$ \\
\hline 131 & 0.2050 & 0.3770 & 0.2020 & 0.0142 & 0.3767 & 0.2006 & -0.11 & -3.750 & 1.621 \\
\hline 150 & 0.2150 & 0.3770 & 0.0220 & 0.0150 & 0.3767 & 0.2006 & -0.11 & -3.938 & 1.615 \\
\hline 200 & 0.2200 & 0.3765 & 0.2030 & 0.0154 & 0.3762 & 0.2016 & 00 & -4.785 & 2.046 \\
\hline 233 & 0.2205 & 0.3750 & 0.2020 & 0.0154 & 0.3748 & 0.2006 & -0.11 & -4.688 & 1.193 \\
\hline 267 & 0.2200 & 0.3785 & 0.2023 & 0.0254 & 0.3782 & 0.2009 & -0.08 & -3.516 & 1.286 \\
\hline 302 & 0.2204 & 0.3765 & 0.2025 & 0.0157 & 0.3762 & 0.2011 & -0.06 & -4.951 & 1.767 \\
\hline
\end{tabular}




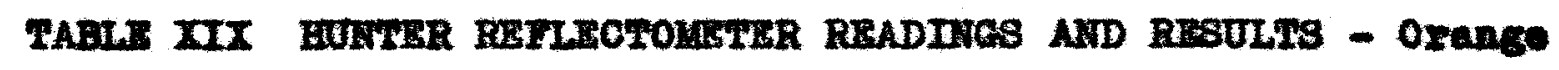

PANEL HO. $10-0-1$

MACHINE READTWES

\begin{tabular}{|c|c|c|c|c|c|c|c|c|c|}
\hline $\begin{array}{c}\text { Hr: } \\
0\end{array}$ & $0.1 \begin{array}{c}B \\
0.2150\end{array}$ & $\begin{array}{c}\text { I. } \\
0.4340\end{array}$ & $\begin{array}{c}t \\
0.3420\end{array}$ & $\begin{array}{c}\text { B } \\
0.0150\end{array}$ & $\begin{array}{c}A \\
0.4344\end{array}$ & $\begin{array}{c}0 \\
0.2412\end{array}$ & $\begin{array}{c}\Delta L \\
-\end{array}$ & $\begin{array}{r}\Delta \mathbf{s}^{*} \\
-\end{array}$ & $\begin{array}{c}\Delta \mathrm{H} \cdot \\
-\end{array}$ \\
\hline 22 & 0.2265 & 0.4280 & 0.2405 & 0.0160 & 0.4283 & 0.2397 & -0.15 & -1.378 & 2.008 \\
\hline 42 & 0.2300 & 0.4230 & 0.2405 & 0.0162 & 0.4253 & 0.2343 & -0.19 & -3.042 & 1.496 \\
\hline 59 & 0.2324 & 0.4230 & 0.2400 & 0.0165 & 0.4233 & 0.2393 & -0.19 & -3.140 & 1.430 \\
\hline 85 & 0.2350 & 0.4230 & 0.2400 & 0.0167 & 0.4233 & 0.2397 & -0.15 & -3.395 & 1.555 \\
\hline 131 & 0.2383 & 0.4090 & 0.2404 & 0.0173 & 0.4088 & 0.2398 & -0.19 & -8.809 & 5.041 \\
\hline 150 & 0.2500 & 0.4200 & 0.2405 & 0.0179 & 0.4201 & 0.2398 & -0.14 & -5.065 & 2.153 \\
\hline 200 & 0.2530 & 0.4205 & 0.2415 & 0.0182 & 0.4206 & 0.2407 & -0.24 & -5.288 & 2.327 \\
\hline 233 & 0.2530 & 0.4170 & 0.2405 & 0.0182 & 0.4170 & 0.2398 & -0.05 & -5.053 & 2,810 \\
\hline 267 & 0.2530 & 0.4210 & 0.2410 & 0.0182 & 0.4212 & 0.2403 & -0.09 & -5.429 & 2.257 \\
\hline 302 & 0.2680 & 0.4170 & 0.2410 & 0.0194 & 0.4170 & 0.2408 & -0.09 & -6.662 & 2.810 \\
\hline
\end{tabular}


TABLE XXI HUNTER BETLECTOMETER ERADTHO AND RESULTS- Orango

PANBLI HO. $7-0-3$

MACHITS READIMGS

\begin{tabular}{|c|c|c|c|c|c|c|c|c|c|}
\hline $\begin{array}{c}\text { Ers. } \\
0\end{array}$ & $\begin{array}{lc}0.2 & B \\
0.2130\end{array}$ & $\begin{array}{c}\mathrm{A} \\
0.2950\end{array}$ & $\begin{array}{c}\mathrm{c} \\
0.1500\end{array}$ & $\begin{array}{c}\text { B } \\
0.0133\end{array}$ & $\begin{array}{c}A \\
0.2903\end{array}$ & $\begin{array}{c}6 \\
0.1472\end{array}$ & $\begin{array}{c}\Delta L^{\prime} \\
-\end{array}$ & $\begin{array}{c}\Delta \boldsymbol{B}^{\prime} \\
-\end{array}$ & $\begin{array}{r}\Delta \mathbf{H}^{*} \\
-\end{array}$ \\
\hline 22 & 0.1970 & 0.3030 & 0.1520 & 0.0135 & 0.3029 & 0.1511 & 0.50 & 2.742 & -1.211 \\
\hline 42 & 0.1990 & 0.3020 & 0.1530 & 0.0237 & 0.3019 & 0.1521 & 0.63 & 1.045 & -0.4591 \\
\hline 59 & 0.2980 & 0.3040 & 0.1535 & 0.0136 & 0.3039 & 0.1526 & 0.59 & 1.524 & -0.6969 \\
\hline 85 & 0.1909 & 0.3004 & 0.1543 & 0.0130 & 0.3002 & 0.1534 & 0.80 & -0.7410 & 0.7763 \\
\hline 131 & 0.2000 & 0.3045 & 0.1558 & 0.0238 & 0.3044 & 0.1549 & 0.99 & 0.3655 & 0.2548 \\
\hline 150 & 0.2066 & 0.3055 & 0.1630 & 0.0143 & 0.3054 & 0.1520 & 1.88 & -6.363 & 3.521 \\
\hline 200 & 0.2105 & 0.3060 & 0.1580 & 0.0146 & 0.3060 & 0.1571 & 1.27 & -1.792 & 0.7944 \\
\hline 233 & 0.2090 & 0.3050 & 0.1570 & 0.0145 & 0.3049 & 0.1561 & 1.14 & -1.444 & 0.5624 \\
\hline 262 & 0.2083 & 0.3090 & 0.1580 & 0.0145 & 0.3091 & 0.2571 & 1.27 & 0.3060 & 0.0598 \\
\hline 302 & 0.2215 & 0.3070 & 0.1580 & 0.0147 & 0.3019 & 0.1571 & 1.27 & -0.3924 & 0.6955 \\
\hline
\end{tabular}


TABL XII HOWWER REYLBCTOMEYRR READTWO AND RESUDT8 - Orango

$$
\text { PAIAL } \text { พ0. } 9-\frac{1}{1-0-1}
$$

MACRINE FEADTIOS

\begin{tabular}{|c|c|c|c|c|c|c|c|c|c|}
\hline $\begin{array}{c}\text { Bre. } \\
0\end{array}$ & $0_{0.2055}{ }^{B}$ & $\begin{array}{c}1 \\
0.4160\end{array}$ & $\begin{array}{c}2 \\
0.2270\end{array}$ & $\begin{array}{c}\text { B } \\
0.0142\end{array}$ & $\begin{array}{c}A \\
0.4160\end{array}$ & $\begin{array}{c}6 \\
0.2258\end{array}$ & $\begin{array}{r}\Delta L^{\prime} \\
-\end{array}$ & $\begin{array}{c}\Delta \mathbf{B}^{\prime} \\
-\end{array}$ & $\begin{array}{r}\Delta \mathbf{E}^{*} \\
-\end{array}$ \\
\hline 22 & 0.2150 & 0.4090 & 0.2230 & 0.0150 & 0.4088 & 0.2217 & -0.43 & -0.0963 & 0.24 \\
\hline 42 & 0.2210 & 0.4050 & 0.2230 & 0.0155 & 0.4047 & 0.2217 & -0.43 & 2.829 & 0.59 \\
\hline 59 & 0.2230 & 0.4051 & 0.2225 & 0.0143 & 0.4048 & 0.2212 & -0.49 & 1.107 & 0.63 \\
\hline 85 & 0.2550 & 0.4030 & 0.2220 & 0.0158 & 0.4027 & 0.2222 & -0.49 & 2.107 & 0.63 \\
\hline 231 & 0.2290 & 0.4020 & 0.2230 & 0.0162 & 0.4016 & 0.2217 & -0.43 & -3.081 & 1.11 \\
\hline 150 & 0.2366 & 0.4020 & 0.2230 & 0.0168 & 0.4016 & 0.2217 & -0.43 & -3.274 & 1.03 \\
\hline 200 & 0.2465 & 0.4065 & 0.2250 & 0.0176 & 0.4062 & 0.2238 & -0.21 & -3.085 & 0.74 \\
\hline 233 & 0.2450 & 0.4000 & 0.2240 & 0.0175 & 0.4096 & 0.2227 & -0.33 & -4.817 & 1.8 \\
\hline 267 & 0.2470 & 0.4050 & 0.2242 & 0.0176 & 0.4047 & 0.2229 & -0.31 & -3.035 & 0.68 \\
\hline 302 & 0.2560 & 0.4010 & 0.2250 & 0.0184 & 0.4006 & 0.2238 & -0.21 & -5.350 & 1.90 \\
\hline
\end{tabular}




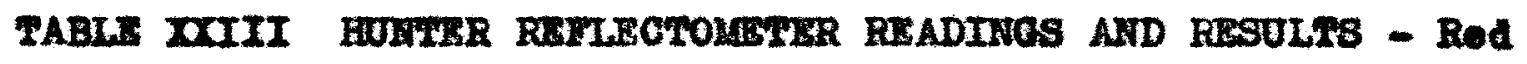

$$
\text { PAIEL No. } 5 \text { - E-1 }
$$

MACRTRE READTMaS

CORRRCTID READTMOS CALCULATED I.C.I. VALOES

\begin{tabular}{|c|c|c|c|c|c|c|c|c|c|}
\hline $\begin{array}{c}\text { Hre. } \\
0\end{array}$ & $\begin{array}{l}0.1 \\
0.1450\end{array}$ & $\begin{array}{c}L^{A} \\
0.2160\end{array}$ & $\begin{array}{c}0 \\
0.5 \\
0.1475\end{array}$ & $\begin{array}{c}\mathrm{B} \\
0.0093\end{array}$ & $\begin{array}{c}A \\
0.2267\end{array}$ & $\begin{array}{c}6 \\
0.0775\end{array}$ & $\begin{array}{c}\Delta \mathbf{L}^{\prime} \\
-\end{array}$ & $\begin{array}{r}\Delta \mathbf{g}^{*} \\
-\end{array}$ & $\begin{array}{c}\triangle \text { II }^{\prime} \\
-\end{array}$ \\
\hline 22 & 0.1485 & 0.2230 & 0.1493 & 0.0096 & 0.2217 & 0.0786 & 0.20 & -0.8680 & -0.0949 \\
\hline 42 & 0.1500 & 0.2205 & 0.1505 & 0.0097 & 0.2192 & 0.0792 & 0.30 & 3.259 & 0.6764 \\
\hline 59 & 0.1540 & 0.2221 & 0.1520 & 0.0100 & 0.2108 & 0.0760 & 0.48 & 4.006 & $0.824,5$ \\
\hline 85 & 0.1555 & 0.2225 & 0.1522 & 0.0202 & 0.2112 & 0.0780 & 0.48 & 3.695 & 0.6891 \\
\hline 131 & 0.1603 & 0.2245 & 0.1563 & 0.0106 & 0.2133 & 0.0726 & 0.90 & 6.596 & 1.1360 \\
\hline 150 & 0.1660 & 0.2250 & 0.1595 & 0.0120 & 0.2138 & 0.0716 & 0.73 & 4.875 & 0.6486 \\
\hline 200 & 0.2640 & 0.2235 & 0.1544 & 0.0104 & 0.2122 & 0.0716 & 0.73 & 5.768 & 2.0170 \\
\hline 233 & 0.2640 & 0.2220 & 0.1550 & 0.0109 & 0.2107 & 0.0718 & 0.76 & 6.886 & 1.4600 \\
\hline 262 & 0.164 & 0.2243 & 0.1543 & 0.0109 & 0.2130 & 0.0716 & 0.73 & 4.986 & 0.8623 \\
\hline 302 & 0.1644 & 0.2240 & 0.1550 & 0.0109 & 0.2127 & 0.0728 & 0.76 & 5.806 & 1.0040 \\
\hline
\end{tabular}


TABLS IITV HUNHAR RETLECTOMETER READINGS AND RESULTS - ROA

PAMA W0. 4 - R-3

MACHIME READINOS CORERCTID READHIOS CALCULATED I.C.I. VALUEB

\begin{tabular}{|c|c|c|c|c|c|c|c|c|c|}
\hline $\begin{array}{c}\text { Hes. } \\
0\end{array}$ & $0.1{ }^{B}$ & $\begin{array}{c}1 \\
1.1990\end{array}$ & $0.5^{0}$ & $\begin{array}{c}B \\
0.0089\end{array}$ & $\begin{array}{c}A \\
0.1976\end{array}$ & $\begin{array}{c}0 \\
0.6910\end{array}$ & $\begin{array}{c}\Delta L^{\prime} \\
-\end{array}$ & $\begin{array}{r}\Delta 8^{\circ} \\
-\end{array}$ & $\begin{array}{r}\Delta \mathbf{H}^{\bullet} \\
-\end{array}$ \\
\hline 22 & 0.1410 & 0.2020 & 0.1365 & 0.0094 & 0.2006 & 0.0711 & 0.37 & -1.801 & 0.4068 \\
\hline 42 & 0.1465 & 0.2020 & 0.1393 & 0.0094 & 0.2006 & 0.0726 & -0.65 & -4.294 & 1.3222 \\
\hline 59 & 0.1465 & 0.2020 & 0.1365 & 0.0096 & 0.2006 & 0.0711 & 0.73 & -1.837 & 0.314 \\
\hline 85 & 0.1490 & 0.2010 & 0.1370 & 0.0096 & 0.1996 & 0.0713 & -0.41 & -2.882 & -0.6458 \\
\hline 131 & 0.2530 & 0.2000 & 0.1380 & 0.0099 & 0.1980 & 0.0729 & -0.52 & -4.617 & 1.0880 \\
\hline 150 & 0.1525 & 0.2013 & 0.1373 & 0.0099 & 0.1997 & 0.0725 & 0.45 & -3.172 & 0.5228 \\
\hline 200 & 0.1563 & 0.1995 & 0.1390 & 0.0202 & 0.1987 & 0.0724 & 0.62 & -5.720 & 1.3540 \\
\hline 233 & 0.1543 & 0.2000 & 0.1380 & 0.0101 & 0.1986 & 0.0719 & 0.52 & -4.725 & 0.9809 \\
\hline 262 & 0.1535 & 0.1990 & 0.1375 & 0.0200 & 0.1996 & 0.0716 & 0.47 & -4.831 & 0.9926 \\
\hline 302 & 0.1545 & 0.1990 & 0.1380 & 0.0101 & 0.1976 & 0.0719 & 0.52 & -5.627 & 1.2110 \\
\hline
\end{tabular}


TABLX IXV HUNTZR BEFLBCTOLATER RBADIMES AND RESULTS - Red

PANRL HO. $1-R-5$

MACHIME READTNGS

CORRECTED READTHES CALCULATED I.C.I. VALUES

\begin{tabular}{|c|c|c|c|c|c|c|c|c|c|}
\hline $\begin{array}{c}\text { Hre. } \\
0\end{array}$ & $0 .{ }_{0.1540}^{B}$ & $L_{0.1410}^{A}$ & 0.50 & $\begin{array}{c}\text { B } \\
0.0088\end{array}$ & $\begin{array}{c}A \\
0.1285\end{array}$ & $\begin{array}{c}0 \\
0.0478\end{array}$ & $\begin{array}{r}\Delta L^{\prime} \\
-\end{array}$ & $\begin{array}{r}\Delta s \\
-\end{array}$ & (7) \\
\hline 22 & 0.1410 & 0.2423 & 0.0955 & 0.0089 & 0.3410 & 0.0487 & 0.21 & 8.9570 & -2.604 \\
\hline 42 & 0.1434 & 0.1405 & 0.0960 & 0.0090 & 0.1399 & 0.0489 & 0.25 & 7.0900 & -2.017 \\
\hline 59 & 0.1465 & 0.1420 & 0.0965 & 0.0092 & 0.14 .13 & 0.0492 & 0.32 & 7.3910 & -2.265 \\
\hline 85 & 0.1483 & 0.1420 & 0.0970 & 0.0094 & 0.1413 & 0.0494 & 0.37 & 6.8360 & -2.238 \\
\hline 131 & 0.1500 & 0.1420 & 0.0980 & 0.0097 & 0.1414 & 0.0500 & 0.50 & 5.4640 & -1.980 \\
\hline 750 & 0.1560 & 0.2433 & 0.0982 & 0.0001 & 0.1426 & 0.0501 & 0.52 & 5.9920 & -2.339 \\
\hline 200 & 0.1583 & 0.1423 & 0.0990 & 0.0104 & 0.1416 & 0.0506 & 0.63 & 3.9560 & -1.871 \\
\hline 233 & 0.1560 & 0.1420 & 0.0990 & 0.0101 & 0.2413 & 0.0506 & 0.63 & 3.8900 & -1.699 \\
\hline 262 & 0.1550 & 0.1422 & 0.0990 & 0.0100 & 0.1415 & 0.0506 & 0.64 & 4.0670 & -1.735 \\
\hline 302 & 0.1570 & 0.1423 & 0.0990 & 0.0102 & 0.1416 & 0.0506 & 0.63 & 4.0870 & -1.769 \\
\hline
\end{tabular}




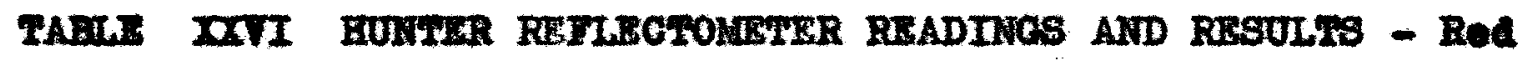

$$
\text { PAIRI 10. } 2-\frac{2-R-3}{2-R-5}
$$

\begin{tabular}{|c|c|c|c|c|c|c|c|c|c|}
\hline \multirow[b]{2}{*}{$\begin{array}{c}\text { Ars. } \\
0\end{array}$} & \multicolumn{3}{|c|}{ MaEIIE READrmes } & \multicolumn{3}{|c|}{ COREEOTED Fraptrres } & \multicolumn{3}{|c|}{ CALCULATED I.O.I. VALUES } \\
\hline & ${ }_{0.2580^{\circ}}^{B}$ & $\begin{array}{c}A \\
0.2620\end{array}$ & $\begin{array}{c}0 \\
.5 \\
0.1090\end{array}$ & $\begin{array}{c}\text { B } \\
0.0091\end{array}$ & $\begin{array}{c}A \\
0.1579\end{array}$ & $\begin{array}{c}a \\
0.0846\end{array}$ & $\begin{array}{c}\Delta L^{*} \\
-\end{array}$ & $\begin{array}{l}\Delta \mathbf{s}^{*} \\
-\end{array}$ & $\begin{array}{c}\Delta \mathbf{H}^{\prime} \\
-\end{array}$ \\
\hline 22 & 0.2453 & 0.2750 & 0.1057 & 0.0093 & 0.1508 & 0.0543 & -5.78 & 4.4 & 21.952 \\
\hline 42 & 0.1473 & 0.2670 & 0.1063 & 0.0095 & 0.1460 & 0.0547 & -5.70 & 41.39 & 20.475 \\
\hline 59 & 0.1486 & 0.2670 & 0.1057 & 0.0096 & 0.1460 & 0.0543 & -5.79 & 42.185 & 20.896 \\
\hline 85 & 0.1490 & 0.2675 & 0.1062 & 0.0096 & 0.1409 & 0.0547 & -5.70 & 41.570 & 20.688 \\
\hline 231 & 0.1510 & 0.2650 & 0.1065 & 0.0098 & 0.1449 & 0.0549 & -5.00 & 39.832 & 20.147 \\
\hline 150 & 0.1535 & 0.2650 & 0.1068 & 0.0100 & 0.1449 & 0.0551 & -5.62 & 39.281 & 20.063 \\
\hline 200 & 0.1555 & 0.2650 & 0.1083 & 0.0102 & 0.1449 & 0.0556 & -5.47 & 37.756 & 19.932 \\
\hline 233 & 0.1540 & 0.2650 & 0.1070 & 0.0100 & 0.1446 & 0.0552 & -5.60 & 39.148 & 19.932 \\
\hline 262 & 0.1565 & 0.2645 & 0.1075 & 0.0108 & 0.1445 & 0.0554 & -5.54 & 38.263 & 19.877 \\
\hline 302 & 0.1565 & 0.2643 & 0.1075 & 0.0108 & 0.1445 & 0.0554 & -5.54 & 38.191 & 19.607 \\
\hline
\end{tabular}




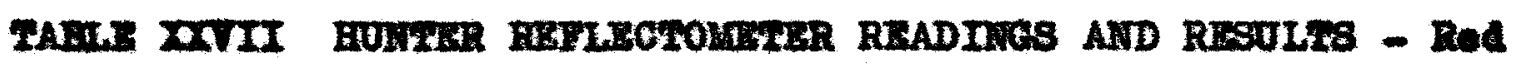

$$
\text { PAIr. no. } 3-\frac{2-2-3}{1-2-5}
$$

MACHTIE RMADIMCS

\begin{tabular}{|c|c|c|c|c|c|c|c|c|c|}
\hline Hrs. & $0.10_{0.1460^{0}}^{\mathrm{B}}$ & $\begin{array}{c}1 \\
0.3010\end{array}$ & $\begin{array}{c}0 \\
0.5 \\
0.1185\end{array}$ & $\begin{array}{c}1 \\
0.0092\end{array}$ & $\begin{array}{c}A \\
0.1660\end{array}$ & $\begin{array}{c}0 \\
0.021\end{array}$ & $\begin{array}{r}\Delta L^{\prime} \\
-\end{array}$ & $\Delta \mathbf{s}^{*}$ & $\Delta$ \\
\hline 23 & 0.1165 & 0.3010 & 0.1190 & 0.0094 & 0.1660 & 0.641 & 0.06 & 0.6965 & 0.0967 \\
\hline 47 & 0.1485 & 0.3045 & 0.1200 & 0.0096 & 0.1680 & 0.619 & 0.16 & 0.3137 & -0.1564 \\
\hline 67 & 0.1510 & 0.3070 & 0.1215 & 0.0098 & 0.1695 & 0.627 & 0.32 & 0.7682 & 0.4842 \\
\hline 85 & 0.1540 & 0.3020 & 0.1200 & 0.0201 & 0.1666 & 0.619 & 0.16 & 1.569 & -0.4646 \\
\hline 133 & 0.1590 & 0.2990 & 0.1220 & 0.0105 & 0.1644 & 0.300 & 0.36 & 4.996 & 0.2453 \\
\hline 159 & 0.1598 & 0.3008 & 0.1205 & 0.0105 & 0.1659 & 0.320 & 0.22 & 2.860 & 0.1168 \\
\hline 180 & 0.1600 & 0.3030 & 0.1205 & 0.0105 & 0.1672 & 0.200 & 0.22 & 1.849 & -0.2315 \\
\hline 216 & 0.1600 & 0.3040 & 0.1205 & 0.0105 & 0.1677 & 0.220 & 0.22 & 1.535 & -0.2390 \\
\hline 245 & 0.1630 & 0.3003 & 0.1214 & 0.0108 & 0.1657 & 0.270 & 0.32 & 4.050 & 0.4386 \\
\hline 277 & 0.1570 & 0.2974 & 0.2195 & 0.0103 & 0.2639 & 0.170 & 0.12 & 3.241 & 0.4043 \\
\hline 300 & 0.2573 & 0.2970 & 0.1204 & 0.0105 & 0.1637 & 0.210 & 0.20 & 4.255 & 0.5222 \\
\hline
\end{tabular}



(1) Z.J. Dunn, Jr, and U.H. Baler. "Orflolal Digeat"-rod of Paint and Tarnish Club, 285, 743, 1948.

(2) H.C. Bryson, Paint Hanufacturer, 25, 255-8, September 1945.

(3). DeBell, J.M., Chem and Met. Engr, 44,311, 1937.

(4) Van Henokeroth, A.W., C1ro 545, National Paint Varnish and Laoquer Assoc., August 1937.

(5) Properties and uses of Bthyl Cellulose, Wm. Kooh, Ind, and Engx. Chem. 29, 687-90 (1937)

(6) R. Forder, Paint Manuracture, 7, 176-8, 220-1 (1937)

(7) Harlod DoWitt Smith, Ind, and Engr. Chom, 29, 1081-4, 1937

(8) Chem. Abstraot. 37 P 3604.

(9) Nelson, H. A. Proo, Am, Soo. Test Mat, 21, 1111-38 (1921)

(10) Dennis and Shelton, J.A.C.S. 52, 3128 (1930)

(11) MoK1n, W.A. Ind, and Eng. Chem 18, 1239 (1926)

(12) Weohhaltz, C.A., Pine Ins't, Am. Abs, 4-113

(13) Chem Abs. 8768

(14) D.X. Stead, J, 011 and Col, Chem, Assoo. 30, 337, 1947.

(15) Broughton, G, and Windebank, C.S, Ind. Eng. Chem., 30, No 4 (1938)

(16) New Fill sidney, M, Hickerson, Dorothy, and Judd, Dean B., J.0, S00 A. 33 385-418 (1943)

(17) Bunter, R.S. National Bureau of Standards, Ciroular C429, July 30, 1942 .

(18) Hunter, R.S.N.B.S. Researoh Paper R.P. 1345 Nor (1940)

(19) Soorfeld, F., Judd, D.B. and Hunter, R.S., A.S.T.H. Bulletin No 110 p. 19 (May 1941) 
(20) Meyers, Natural and Synthet10 High Polymers. Vol IV

(21) J.J. Mat1ello, Proteotive and decorative ooatings, Vol II pp 427-440 447, 409. J. W11ey and Sons 1942.

(22) Mason and Manning. The Tochnology of Plastics and Resin., D. Van Nostrand Co.

(23) Ethocel Hand Book. Dow Chemioal Company.

(24) W1Lson, S.P., Pyroxylin Enamels and Laoquers, D. Van Mostrand Co., N.I. 2nd Ed. 1928.

(25) Munse11, A.H. Munse11 Book of Colorg" Munse11 Color Co. Ino. 1942 Baltimore M.D. 
VITA 
The author was born in Lahore (Punjab) Paktstan, on August 21, 1922. His father Chaudhr1 Zahur Ahmad, and mother Saliha Begum, were native to the Province of the Punjab (Pakiatan).

At the age of seren years, Mr. Ahmed joined the primery sohool and then Muslim High Sohool, from where he graducated in 1938. The author attended the Forman chriatian College Labore, following his high school graduation, in 1938 and obtained the degree of Baohelor of Scienoe in 1944. In 1945 he qualified for the degree of Bachelor of Solenoe (Hons. Soh) to join the Master of Solence olass in Toohnology in the Punjab College of Englneering and Technology.

Mr. Ahmad obtalned the Master of Solenoe in Teohnology degree in 1946 and was selooted by the prepartition Government of India for advanced studies in Palnts in the Onited States of Amerioa.

Due to sea passage diffioulties Mr. Ahmad had to wait for about elght monthe during which time he served as an instruotor in the Government Leather Tanning Institute, Juliundar. Meanwhile division of British Indie took place and the author opted for Pakiatan.

He proceeded to the United States of Amerioa in September 1947 and joined the Speed Solentiflo Sohool in Ootober 1947, where he worked for the degree of Master of Chemical Englneering with the aoceptance of this thesis he w11l obtein the degree of Masters in Chemlaal Bnglneoring in June 1949. 
This researoh wa made possible

through a rellowshlp grant from

The Dniversity of Loulsville Departiont of Chemloal Englneering

as a portion of contracted researoh with

Dow Ohenteal Company 